\title{
Barnperspektiv i barnavårdsutredningar - med barns hälsa och barns upplevelser i fokus
}

\author{
Elin Hultman
}

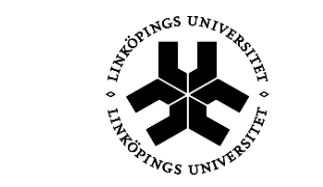

Linköpings universitet

Linköping Studies in Arts and Science No. 600

Studies from the Swedish Institute for Disability Research No. 56

Linköpings universitet, Institutionen för beteendevetenskap och lärande Linköping 2013 
Linköping Studies in Arts and Science No. 600

Studies from the Swedish Institute for Disability Research No. 56

Vid filosofiska fakulteten vid Linköpings universitet bedrivs forskning och ges forskarutbildning med utgångspunkt från breda problemområden. Forskningen är organiserad i mångvetenskapliga forskningsmiljöer och forskarutbildningen huvudsakligen i forskarskolor. Gemensamt ger de ut serien Linköping Studies in Arts and Science. Denna avhandling kommer från Institutet för handikappvetenskap vid Institutionen för beteendevetenskap och lärande

Distribueras av:

Institutionen för beteendevetenskap och lärande Linköpings universitet

58183 Linköping

\section{Elin Hultman}

Barnperspektiv i barnavårdsutredningar

- med barns hälsa och barns upplevelser i fokus

Upplaga 1:1

ISBN 978-91-7519-457-8

ISSN 0282-9800

ISSN 1650-1128

(C)Elin Hultman

Institutionen för beteendevetenskap och lärande, 2013

Tryckeri: LiU-tryck, Linköping, 2013 


\section{Abstract}

Avhandlingens övergripande syfte var att fördjupa kunskapen om hur socialtjänsten synliggör barns fysiska och psykiska hälsa samt barns egna upplevelser i barnavårdsutredningar. Resultaten diskuteras utifrån rättsliga förutsättningar samt teorier om barn som subjekt och sociala aktörer. De fyra delstudierna visar att det finns begränsningar i hur hälsan samt barns upplevelser beskrivs om man vill förstå deras behov av stöd. En anledning till detta kan vara att den rättsliga regleringen inte per automatik ger barn status som subjekt och aktörer. Resultaten tyder på att barnperspektivet $\mathrm{i}$ både den rättsliga regleringen och genomförandet av barnavårdsutredningar har stärkts jämfört med vad som visats i tidigare forskning men det behövs en utvecklad analys och argumentation kring barns upplevelser och barns hälsa. En sådan förståelse ger förutsättningar för att barn blir synliggjorda utifrån sina unika förutsättningar vilket säkerställer att socialtjänsten tar hänsyn till deras unika behov.

Nyckelord: barnavårdsutredningar, dokumentation, barns fysiska och psykiska hälsa, barns upplevelser 


\section{Artiklar}

Den här avhandlingen bygger på fyra artiklar. I texten refereras de till som studie 1, 2, 3 och 4 .

1. Hultman, E., Alm, C., Cederborg, A-C., \& Fälth Magnusson, K. (2013). Vulnerable children's health- as described in investigations of reported children. Child \& Family Social Work,18 (2), 117-128. doi:10.1111/j.13652206.2011.00807.x

2. Hultman, E., Cederborg, A-C., \& Fälth Magnusson, K. ( Submitterad). Social workers' assessments of children's health when arguing for children's needs.

3. Hultman, E., \& Cederborg, A-C. (Submitterad). Representations of Children's Voices about their health in Social Services arguments in support of their decision.

4. Hultman, E., \& Cederborg, A-C. (2013). How Social Workers Portray Children's Perceptions When Constructing Their Identities. International Journal of Social Science Studies, 1(2), 73-81. doi:10.11114/ijsss.v1i2.130 


\section{Prolog}

I rapporter om barns hälsa lyfts ofta fram att barn i Sverige har en god hälsa i jämförelse med andra länder. Det har dock uppmärksammats att det finns hälsoskillnader mellan olika grupper av barn även i Sverige och att barn i socialt utsatta miljöer löper större risk för ohälsa än andra barn (Socialstyrelsen, 2013b).

Mitt intresse för hur socialsekreterare fokuserar på barns hälsa i utredningar om barns behov av stöd och skydd väcktes utifrån en självkritisk reflektion. Jag insåg att jag under mitt arbete som socialsekreterare inte på ett tillfredställande sätt fokuserat på betydelsen av medicinska diagnoser eller andra hälsoaspekter för barns livssituation. Detta trots vetskapen om att barns fysiska och psykiska hälsostatus både kan påverka och påverkas av deras sociala situation. Min fundering var att andra mer tydligt framträdande aspekter av barns liv och akuta situationer riktade uppmärksamheten åt ett annat håll. Den här avhandlingen kom att bli en vidare analys av hur socialsekreterare fokuserar på barns fysiska och psykiska hälsa $\mathrm{i}$ barnavårdsutredningar. Fokus är också på hur barns egna uppfattningar om sig själva och sin livssituation ges utrymme i utredningar där det initialt uppges att det finns en oro för barnets hälsa. 


\section{INNEHÅLLSFÖRTECKNING}

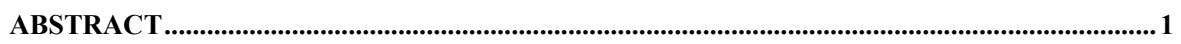

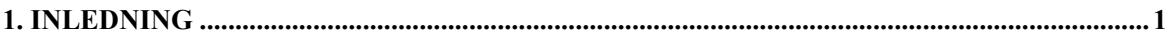

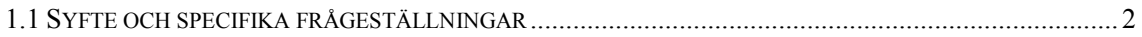

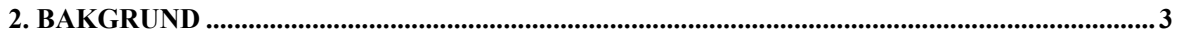

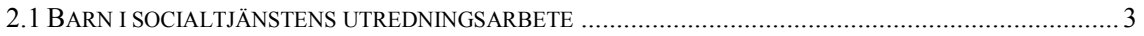

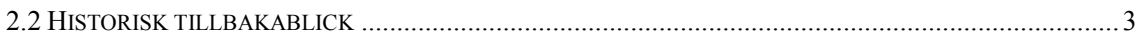

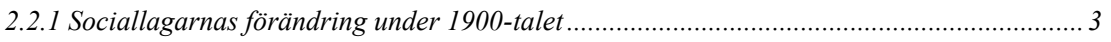

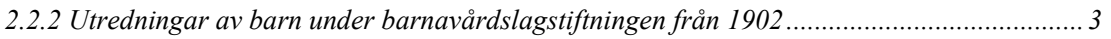

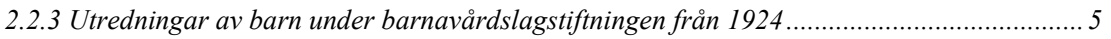

2.2.4 Utredningar av barn under barnavårdslagstiftningen från 1960 ....................................... 6

2.2.5 Socialtjänstlagens införande 1982 .......................................................................... 7

2.3 SOCIALTJÄNSTENS BARNAVÅRDSUTREDNINGAR I BÖRJAN AV 2000-TALET - KONTEXTUELLA

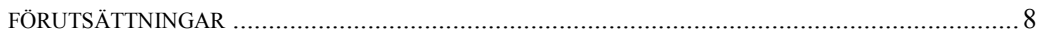

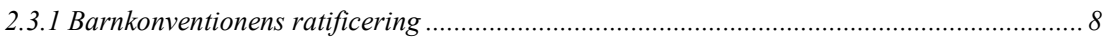

2.3.2 Barnsyn i den rättsliga regleringen ....................................................................... 9

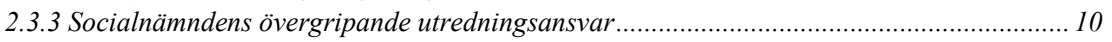

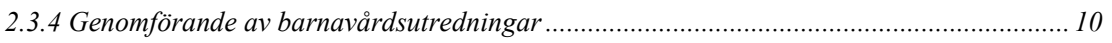

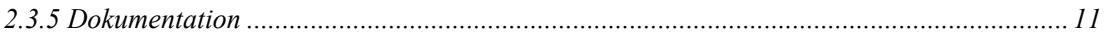

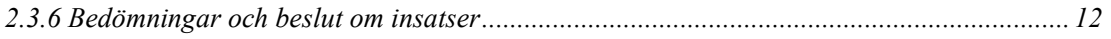

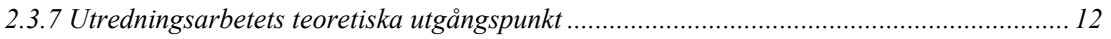

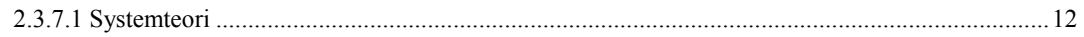

2.3.7.2 Utvecklingspsykologiska teorier......................................................................................... 14

2.3.8 Utredningsarbetets organisatoriska förutsättningar .................................................... 14

2.3.8.1 Handläggnings- och dokumentationssystemet Barns Behov i Centrum (BBIC) ......................... 14

2.3.8.2 Handläggning utifrån BBIC ................................................................................................. 15

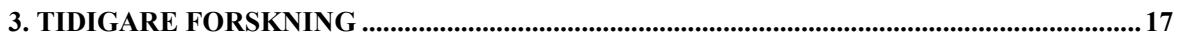

3.1 FYSISK OCH PSYKISK HÄLSA HOS BARN I SOCIALTJÄNSTENS VERKSAMHET .................................... 17

3.2 PÅVERKANSFAKTORER FÖR BARNS FYSISKA OCH PSYKISKA HÄLSOUTVECKLING.......................... 18

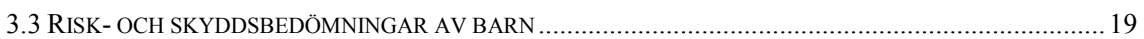

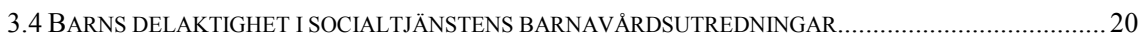

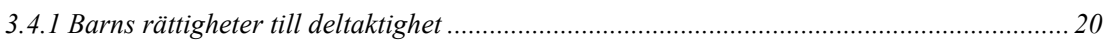

3.4.2 Inkludering av barn i socialtjänstens utredningsarbete ................................................ 21

3.4.3 Synliggörande av barn i barnavårdsutredningar ........................................................... 21

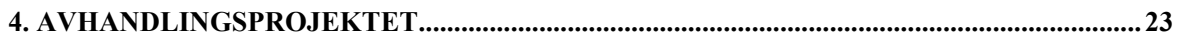

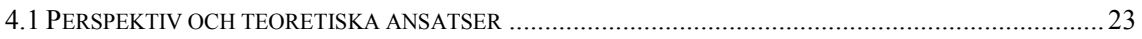

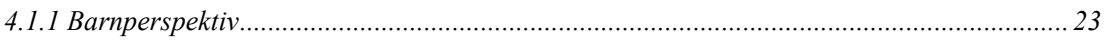

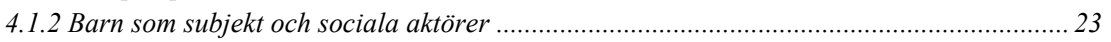

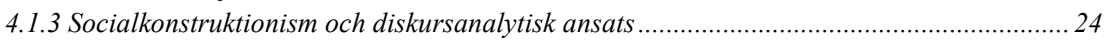

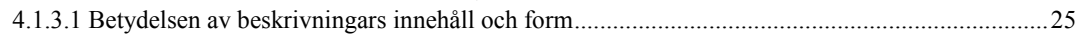

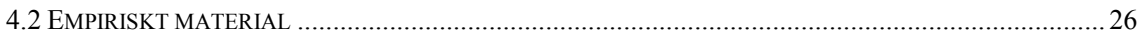

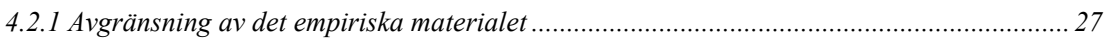

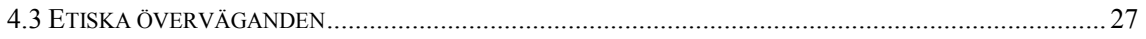

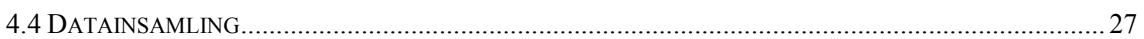

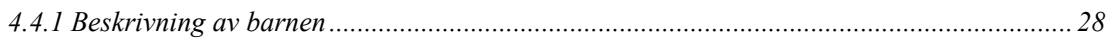

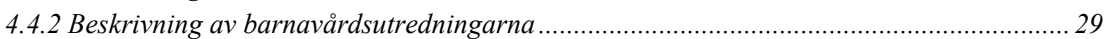

4.4.3 Skriftliga och muntliga uttalanden från medicinsk expertis ............................................ 31 


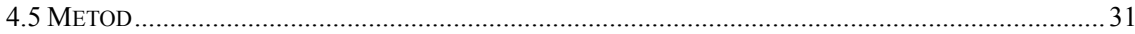

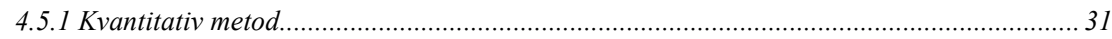

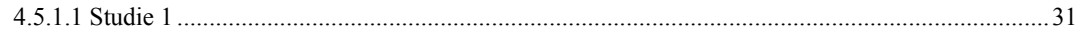

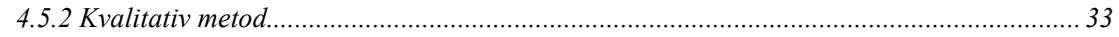

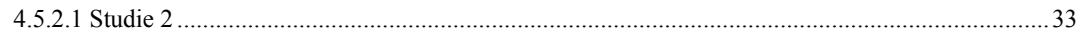

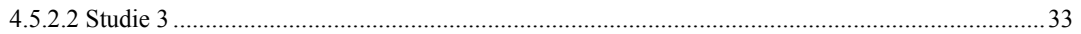

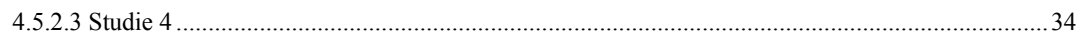

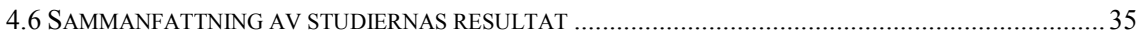

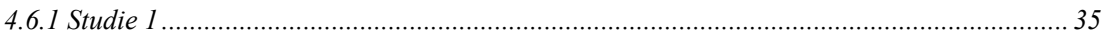

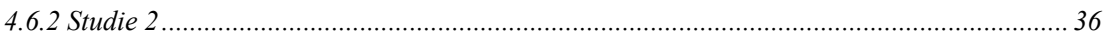

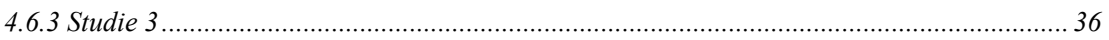

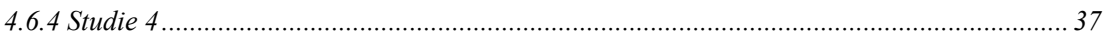

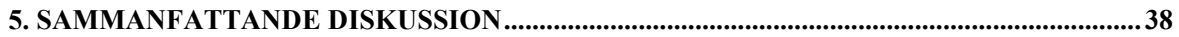

5.1 BARNS STATUS SOM SUBJEKT OCH SOCIALA AKTÖRER- RÄTTSLIG REGLERING ............................38

5.2 SKILDRINGAR AV BARNPERSPEKTIV I BARNAVÅRDSUTREDNINGARNA ....................................... 40

5.2.1 Synliggörande av barns fysiska och psykiska hälsa .................................................... 40

5.2.2 Synliggörande av barns perspektiv ......................................................................... 41

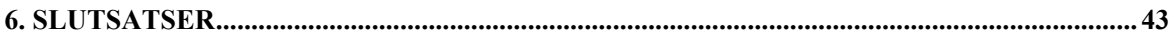

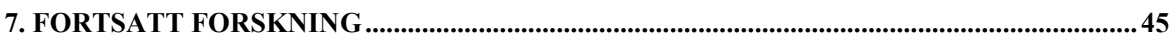

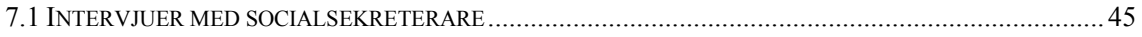

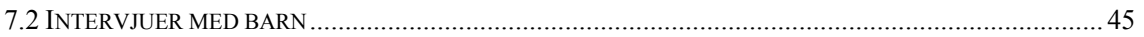

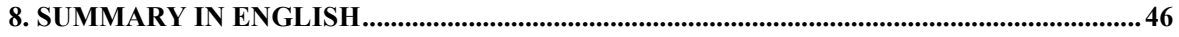

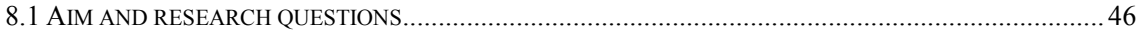

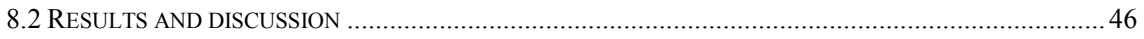

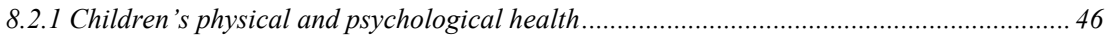

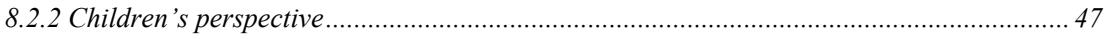

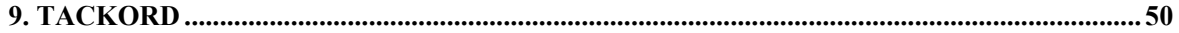

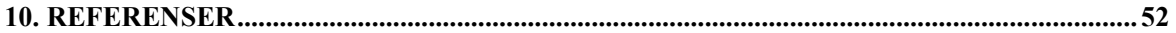





\section{Inledning}

Socialnämnden har enligt socialtjänstlagen (SoL 2001:453) ett ansvar för att tillsammans med föräldrar se till att barn får en god fysisk och social utveckling och att de barn som riskerar en ogynnsam utveckling får det stöd och skydd de behöver. Socialtjänsten är därmed skyldig att inleda en barnavårdsutredning om de får kunskap om att barn lever under sådana förhållanden som kan tänkas leda till att de har behov av en insats från socialnämnden (SoL $5: 1)$.

I Sverige har socialtjänstens barnavårdsutredningar tidigare studerats på flera olika sätt. Dessa studier har exempelvis uppmärksammat hur utredningsprocessen går till (Cocozza, 2007; Östberg, 2010), barnavårdsutredningarnas rättsliga förutsättningar (Friis, 2003; Leviner, 2011), barns rättsliga ställning i utredningar om tvångsvård (Mattsson, 2002) den historiska förändringen av organisatoriska villkor för (Lundström, 1993) och processen vid utredningar som leder till tvångsomhändertagande av barn (Ponnert, 2007), vilken typ av information som dokumenterats i akterna (Bernler \& Johansson, 1993), vems åsikter som citeras och rapporteras i utredningarna (Hydén, 1995; Hollander, 1985) samt övergripande utredningsmetodik (Edvardsson, 2012a, 2012b). Dessa studier visar att både genomförandet och kvaliteten på socialtjänstens barnavårdsutredningar kan variera beroende på hur arbetet med barnavårdsutredningar organiseras. De visar också att barnets delaktighet $\mathrm{i}$ barnavårdsutredningarna kan vara begränsad. Dessutom uppmärksammas att arbetet med att bedöma barns livssituation kan vara mycket komplext bland annat på grund av att föräldrar och barn kan ha olika intressen. Tidigare forskning visar också att socialtjänstens arbete med barn efter beslut om insats kan fortsätta vara svårt men också otillfredsställande. Det har exempelvis visat sig att barn som placerats av socialtjänsten har en sämre hälsa än barn som inte har varit placerade (Vinnerljung, Hjern \& Lindblad, 2006; Socialstyrelsen, 2013b) och att det kan finnas brister i det medicinska omhändertagandet av placerade barn (Kling, 2010; Socialstyrelsen, 2000). 


\subsection{Syfte och specifika frågeställningar}

Trots ett stort antal studier som uppmärksammat socialtjänstens arbete i Sverige saknas det kunskap om hur socialsekreterare lyfter fram och argumenterar för barns fysiska och psykiska hälsa i barnavårdsutredningar när de ska bedöma barns behov av stöd och skydd. Dessutom saknas specifik kunskap om hur barns upplevelser synliggörs i utredningar där det initialt framkommer en oro för deras hälsa. Syftet med den här avhandlingen är därför att utveckla och fördjupa kunskapen om hur socialtjänsten i skriftliga barnavårdsutredningar avseende barns behov av stöd och skydd synliggör barns fysiska och psykiska hälsa samt barns egna upplevelser.

Mer specifikt belyser avhandlingen följande frågeställningar:

Vilka hälsoaspekter uppmärksammar socialsekreterare när de utreder barns livssituation? (Studie 1)

Hur argumenterar socialsekreterare för barns fysiska och psykiska hälsa i bedömningar och beslut om barns behov av stöd och skydd? (Studie 2)

Hur synliggörs barns upplevelser av sin egen hälsa i socialsekreterares argumentation för beslut? (Studie 3)

Hur synliggörs barns perspektiv på sig själva och sin livssituation i utredningar genomförda enligt handläggnings- och dokumentationssystemet BBIC när det initialt finns en oro för barns hälsa? (Studie 4)

Resultaten diskuteras utifrån de förutsättningar lagstiftning och andra nationella riktlinjer ger. 


\section{Bakgrund}

\subsection{Barn i socialtjänstens utredningsarbete}

Begreppet barnavårdsutredning inkluderar all den verksamhet i socialtjänstens individ- och familjeomsorg vars syfte är att göra det möjligt för socialnämnden att fatta beslut $i$ ett barnärende (Prop. 1979/80:1). Begreppet utredning kan också användas för den skriftliga sammanställningen av det material som finns i ett ärende och som ligger till grund för beslutsfattandet (Socialstyrelsen, 2006b). Avhandlingen fokuserar främst på det sistnämnda.

Det sociala utredningsarbetet styrs av rättslig reglering (det vill säga rättsligt bindande såväl som vägledande riktlinjer) men influeras även av politiska strömningar, tillgängliga resurser och dominerande ideologiska värderingar i samhället. Därmed utgår det sociala arbetets praktiska verksamhet inte bara från kunskap i form av vetenskap och beprövad erfarenhet (Börjeson, 2010; Duffy \& Collins, 2010) utan den är också beroende av samhällets syn på barn och deras livssituation. Barnsyn och de problem socialtjänsten förväntas utreda och åtgärda är föränderliga vilket betyder att förutsättningarna för socialtjänstens utredningsarbete i Sverige förändras över tid (Börjeson, 2010; Meeuwise \& Swärd, 2013).

\subsection{Historisk tillbakablick}

\subsubsection{Sociallagarnas förändring under 1900-talet}

Ursprunget till det som i dag kallas social barnavård i Sverige kan kopplas till de sociala och politiska förändringar som skedde i samband med industrialisering och urbanisering $\mathrm{i}$ västvärlden under mitten av 1800-talet till början av 1900-talet. Denna strukturella förändring i samhället ansågs orsaka moraliskt förfall i familjer där föräldrar inte hade tid att fostra sina barn som tidigare. För att komma till rätta med denna utveckling skulle individer och deras beteenden regleras av samhället (Lundström, 1993; Sundkvist, 1994). Politiska och sociala reformer som utgick ifrån ett offentligt ansvar för individen fick därigenom genomslagskraft i början av 1900-talet. Dessa gav statliga myndigheter rätt att ingripa mot, exempelvis, vanartiga barn (Meuwisse \& Swärd, 2013).

Under 1900-talet tillkom vartefter ett antal lagar som på olika sätt reglerade socialtjänstens barnavårdsutredningar. I följande avsnitt beskrivs kortfattat lagen om vanartade och försummade barn från 1902 (1902:67), barnavårdslagen från 1924 (1924:361), barnavårdslagen från 1960 (1960:27) samt den barnsyn som utmärkte lagstiftningen och vilka konsekvenser denna lagstiftning fick.

\subsubsection{Utredningar av barn under barnavårdslagstiftningen från 1902}

Barnavårdslagstiftningen från 1902 bestod av tre olika lagar: en berörde fosterbarnsvården, en annan var inriktad mot uppfostran av vanartade och försummade barn och en tredje reglerade behandling av minderåriga förbrytare (Falk, 2006). I lagen om vanartade och försummade barn (1902:67) fanns riktlinjer för samhällets rätt och skyldighet att ingripa mot dessa två grupper av barn. Lagen gällde barn under 15 år. Den barnsyn som präglade lagstiftningen handlade om att barn ansågs vara, och skulle bete sig, annorlunda än vuxna. De värderades inte heller på samma sätt som vuxna. Barns plats ansågs vara i hemmet hos 
föräldrarna och de skulle därmed inte röra sig fritt i samhället. Föräldrarna förväntades ha kontroll över sina barns liv och föräldrarna kunde kritiseras om de inte uppfyllde förväntningarna. Barn skulle leka istället för att arbeta och inte ha egna nöjen utanför familjen. De skulle dock inte ha för mycket frihet eftersom det då fanns en risk att de förlorade respekt för såväl föräldrar som världs- och gudsmakten. De barn som protesterade mot vuxnas kontroll och agerade självständigt ansågs vara vanartade. Det handlade om barn som begick brottsliga handlingar men också om barn som inte skötte skolan eller på annat sätt uppförde sig "omoraliskt" vilket gjorde det omöjligt för hemmet och skolan att hantera dem. De barn som ansågs vara försummade var de som på grund av föräldrarnas omoraliska agerande hade en potentiell risk att bli vanartiga, även om de ännu inte gett uttryck för det $\mathrm{i}$ sitt eget handlande (Sundkvist, 1994). Lundström (1993) menar att lagstiftningens syfte vid den tiden handlade om att skydda samhället från negativ påverkan från vanartade barn och inte i första hand om att skydda barnen. Det kan tolkas som att den sociala barnavårdens arbete utgick ifrån en barnsyn som innebar att barn skulle vara beroende av och kontrolleras av vuxna.

I lagen om vanartade och försummade barn (1902:67) beskrevs att ordförande i barnavårdsnämnden var ansvarig för de utredningar som genomfördes. Om det inte fanns en nämnd blev det ordförande i skolrådet som ansvarade för utredningsarbetet (Lundström, 1993). På de platser där det fanns en barnavårdsnämnd skulle kyrkoherden vara ordförande och nämnden skulle bestå av ytterligare fyra personer som ansågs ihärdiga i sin vilja att uppfostra barn och ungdomar (Falk, 2006). Nämnderna kom att bestå av personer med en hög ställning i samhället. Lärare och lärarinnor var vanliga yrken bland ledamöterna men det kunde även vara pastorer och filosofie doktorer som var med och fattade beslut (Swärd, 1993). Också rätten att anmäla begränsades till inflytelserika personer i samhället då det endast var länsstyrelse, magistrat, polis, präster och lärare som kunde göra anmälningar. Om anmälan gjordes av någon annan än dessa personer skulle ordförande i barnavårdsnämnden bestämma om anmälan skulle behandlas. Syftet med dessa begräsningar beskrivs vara att nämnden skulle slippa ta upp ärenden i onödan. Anmälningsorsakerna varierade men i en studie som belyst barnavårdsnämndens arbete i Norrköping mellan 1903-1925 fann man att den vanligaste orsaken till anmälan var att barnen uppfattades ha ett dåligt hem på grund av att föräldrarna inte ansågs vara tillräckligt goda föräldrar. Övriga anledningar till anmälan handlade om barns beteende, exempelvis att de stal eller misskötte skolan (Sundkvist, 1994).

Barnavårdsnämnderna hade i uppgift att noga utreda barns levnadsförhållanden och beteende. Förutom hembesök av ledamöter i nämnden samlades uppgifter om barnet in från framförallt lärare. Ibland fick läkare också bedöma barns hälsa. Det var möjligt att kalla barn och föräldrar till nämndens möte då beslut skulle fattas. Det har dock påvisats att barn sällan tillfrågades om sin egen upplevelse av situationen och informationen i utredningarna var begränsad vad gäller barns uppfattningar om de beslut som fattades. Däremot framgår att nämndens slutgiltiga bedömning oftast var i överensstämmelse med den åsikt som framförts av anmälaren vad gäller barnets situation och beteende (Sundkvist, 1994). Det var endast ett fåtal ärenden som avskrevs efter att utredningen genomförts (Swärd, 1993). Detta kan tolkas som att familjerna eller barnen hade begränsade möjligheter att påverka nämnden om det som anmälts ansågs trovärdigt. 
I 1902 års barnavårdslag om vanartade och försummade barn fanns fyra olika åtgärder för nämnden att besluta om: varning eller förmaning till familjen, hembesök, aga och avskiljande, det vill säga placering av barnet utanför hemmet (Sundkvist, 1994). Insatserna kunde på så sätt även riktas mot barns vanartade beteende även om barnen inte ansågs ansvariga för hur deras liv gestaltade sig (Ohrlander, 1992).

\subsubsection{Utredningar av barn under barnavårdslagstiftningen från 1924}

Vid tiden för införandet av 1924 års barnavårdslagstiftning ansågs familjers bristande moral fortfarande som en viktig orsaksförklaring till barns och familjers svårigheter. Barns vanart och sökandet efter orsaker blev nu även en vetenskaplig fråga. Den barnsyn som präglade lagstiftningen utgick ifrån att experter inom olika områden var bäst lämpade att ge en bild av det enskilda barnet och dess livssituation (Lundström, 1993; Swärd, 1993; von Koch, 1945). Den medicinska sakkunskapen hade fått allt större inflytande inom barnavården under början av 1900-talet och uppfattningen om att beteenden och individuella avvikelser också kunde bero på själsliga sjukdomstillstånd började sprida sig. Den teoretiska och metodologiska utvecklingen innebar en stor tilltro till att barns avvikelser ansågs kunna diagnostiseras och behandlas (Falk, 2006; Lundström, 1993, 1996; Ohrlander, 1992).

En skillnad från den tidigare barnavårdslagstiftningen var att samhället genom 1924 års reform även kunde ingripa för att skydda barn som på olika sätt ansågs ha en utsatt livssituation istället för att bara fokusera på att skydda samhället från vanartade och försummade barn. Detta innebar att ingripanden på grund av föräldrars vanvård eller misshandel av barnet också var möjlig att genomföra (Lundström 1993, 1996; von Koch, 1945). Anledningen till detta beskrivs vara ambitionen att gynna Sveriges framtid vilket då krävde att samhället räddade barn och såg till att de fick tillgång till utbildning, hälso- och sjukvård samt god uppfostran. Grundtanken var därmed fortfarande att kontrollera och övervaka enskilda för att skydda samhället mot de individer vars beteenden ansågs vara individuella moraliska avvikelser (Falk, 2006; Lundström, 1993). Skillnaden var att problemen inte längre enbart ansågs vara koncentrerade till arbetarklassen i städerna utan att de förekom i hela landet. Det var dock fortfarande ett stort fokus på barn till fattiga föräldrar. Föräldrar ansågs ansvariga för kontroll av sina barn och de skulle se till att de inte blev vanartiga och samhället skulle endast ingripa om föräldrarna inte klarade av att ta ett sådant föräldraansvar (Lundström, 1993).

I och med barnavårdslagen från 1924 (1924:361) infördes krav på organisatoriska förändringar med syftet att åstadkomma en enhetlig barnavård i Sverige (Lundström, 1993, 1996). Det blev obligatoriskt för varje kommun att inrätta särskilda barnavårdsnämnder och det var de som skulle utreda barn och deras livssituation (Falk, 2006). I lagen preciserades att nämndens ledamöter skulle vara: en representant från kommunens fattigvårdsstyrelse, en präst, en läkare, en lärare, minst en kvinna samt ytterligare två ledamöter som man visste var intresserade av barn och ungdomsvård. Det påtalades också att en juridiskt sakkunnig gärna skulle ingå i nämnden (Falk, 2006). Kommunerna kunde anställa socialvårdstjänstemän men de flesta kommuner fortsatte att använda nämndemän i barnavården (Lundström, 1993).

I lagstiftningen från 1924 presenterades vilken information som skulle inkluderas i utredningen för att beslut skulle kunna fattas. Informationen skulle fokuseras på barnen och familjernas vardag (Lundström, 1993; Swärd, 1993). Samtidigt angavs att nämnden hade 
möjlighet att begära en läkarundersökning när det fanns misstanke om att barnets vanart eller andra missförhållanden kunde bero på sjukdom, andliga eller kroppsliga problem hos barnet. Även vid misstanke om att föräldrarna var sjuka skulle läkares yttrande kunna inhämtas (von Koch, 1945). Förutom läkaren kunde de som var ansvariga för barnets undervisning eller polisen, om de hade kontakt med aktuellt barn, delta i nämndens överläggning om barnets situation. Om barnet tillhörde en främmande tro kunde även föreståndare för den församlingen kallas till mötet. Det poängteras att en grundlig och allsidig utredning av barnets situation var betydelsefullt för att kunna göra rätt bedömning men att ingen av dem som berördes av utredningen fick fara illa av informationsinsamlandet (Lundström, 1993; von Koch, 1945). De insatser som var möjliga i 1924 års barnavårdslag innebar, precis som i lagen från 1902, en upptrappning i repressiva åtgärder. Som en första åtgärd, då vanarten eller försummelsen inte ansågs alltför allvarlig, kunde barn och föräldrar ges en varning där de påmindes om vilka åtgärder som riskerades om de inte förändrade sitt beteende. Nämnden kunde också besluta om fortsatta oanmälda besök hos familjen för att övervaka utvecklingen och för att påverka familjen till att förändra sitt liv. Den mest omfattande åtgärden var ett omhändertagande av barnet och det skulle ske då andra åtgärder ansågs verkningslösa (Lundström, 1993; von Koch, 1945).

Under den första hälften av 1900-talet kunde dokumentationen av de ärenden som behandlades av barnavårdsnämnden vara bristfällig. I det som går att utläsa från lagtexter och tidigare studier framkommer dock att utredningsarbetet även efter införandet av 1924 års barnavårdslag till stor del bestod av en bedömning av de missförhållanden som anmäldes. Det kunde innebära att det var anmälan som låg till grund för de beslut som fattades.

Utredningstexter från den här tiden kunde innehålla moraliserande värderingar i beskrivningar av familjer och det enskilda barnet fick fortsatt begränsade möjligheter att bidra med sin uppfattning innan bedömningar gjordes och beslut fattades (Swärd, 1993). Det finns samtidigt studier som visar att utredningsarbetet kunde variera mellan olika nämnder beroende på om det fanns anställda tjänstemän eller om arbetet bedrevs av lekmän. Vid de nämnder där socialarbetare var anställda verkar det ha funnits en större benägenhet att standardisera utredningar vad gäller både innehåll och form (Lundström, 1993).

\subsubsection{Utredningar av barn under barnavårdslagstiftningen från 1960}

I förarbeten till lagen om samhällets barnavård 1960 (1960:27) framställs en medicinsk/psykiatrisk förklaringsmodell som central för uppkomsten av avvikande beteende. Hur samhälleliga förhållanden och strukturer kunde påverka människors liv uppmärksammades inte alls på samma sätt som tidigare (Lundström \& Sallnäs, 2003). Även om läkare tidigare hade haft en dominerande ställning vid tolkning av barns situation förflyttades fokus från biologi och psykopati som orsaksförklaringar till avvikande beteende till ett mer psykoanalytiskt perspektiv. Det sistnämnda perspektivet innebar att uppmärksamhet riktades mot hur störningar i familjen påverkade barnen. Redan 1942 gjordes ett tillägg i lagstiftningen som innebar att nämnden kunde ingripa om det ansågs föreligga risk för barnets själsliga hälsa. Sådan påverkan uppfattades kunna leda till allvarliga skador på det psykiska hälsotillståndet för lång tid framåt (Lundström, 1993, 1996; von Koch, 1945).

1960 års lag om samhällets barnavård (1960:27) riktades mot barn som det ansågs finnas skäl att ingripa emot på grund av förälder eller annan fostrares beteende, eller på grund 
av att barnets eget beteende ansågs problematiskt (Lundström, 1993; von Koch, 1945).

Förutsättningar för beslutsfattande i 1960 års lagstiftning liknar de som fanns i 1924 års lag. De insatser som var möjliga att genomföra reglerades genom en successiv upptrappning av straff och kontroll för varje steg. Det första steget i insatstrappan var råd och stöd, följt av varning, föreskrifter om den unges förhållande, övervakning och slutligen tvångsomhändertagande (Falk, 2006; Lundström, 1993). Barn hade ingen självständig rättslig ställning utan ansågs vara en del av familjen. Exempelvis, ansågs ingripanden med tvångsvård för barn under 15 års ålder endast kunna genomföras på grund av föräldrarnas omsorgsbrister (Mattsson, 2006).

Lagen från 1960 var överlag mer detaljerad i beskrivningar om hur det sociala utredningsarbetet skulle gå till i jämförelse med tidigare lagstiftning. Här fanns också större krav på att utredningar skulle vara juridiskt korrekta (Lundström, 1996). Det var socialvårdstjänstemän anställda $\mathrm{i}$ kommunerna som skulle genomföra utredningsarbetet $\mathrm{i}$ stället för, som tidigare, lekmän i nämnderna. Syftet var att skapa bättre förutsättningar för att utredningar om barns livssituation skulle bli mer fullständiga och tillförlitliga (Lundström, 1993, 1996). Tidigare studier visar också att själva genomförandet av utredningarna blev mer standardiserat. De skrivna utredningarna kunde exempelvis organiseras enligt rubriker såsom: anledning till utredning, tidigare åtgärder, förhållanden gällande familj och sysselsättning, aktuell situation samt förslag till beslut. Formatet på utredningarna blev därmed likriktat. Likaså formades även innehållet i utredningarna på likartat sätt trots att det kan ha funnits skillnader mellan ärenden (Swärd, 1993). Dessutom karaktäriserades utredningarna av att andra personer, som exempelvis lärare, arbetsgivare, poliser och läkare fick företräde att beskriva barn och deras livssituation. Exempelvis kunde läkarutlåtanden bifogas som underlag för nämndens bedömning om ett omhändertagande. Intygsskrivandet verkar samtidigt ha varit en ren formalitet. Läkaren behövde inte ha någon kontakt med barnen och läkarna instämde oftast i de bedömningar som barnavårdsnämnderna redan gjort (Swärd, 1993). Från att det tidigare var läkare som ensamma gett förklaringar till barns utsatthet och avvikelser började även andra mer samhälls- och systemteoretiska inriktningar ta plats inom barnavården från 1960-talet. Det innebar även att socialarbetarna så småningom blev mer delaktiga i att förklara avvikelser jämfört med tidigare då läkarkåren hade en dominerande ställning vid orsaksförklaringar (Lundström, 1993).

\subsubsection{Socialtjänstlagens införande 1982}

I början av 1980-talet kom den första versionen av socialtjänstlagen (1980:621) som blev gällande lag från 1982. Den ersatte de äldre sociallagarna barnavårdslagen (1960), nykterhetsvårdslagen (1954) och socialhjälpslagen (1956). Socialtjänstlagen instiftades som ett svar på den kritik som riktats mot tidigare lagstiftning och det praktiska arbetet som ansågs ha förstärkt individers utsatthet (Börjeson, 2010). Införandet av socialtjänstlagen innebar att frivillighet och service samt samverkan mellan klienter och socialtjänst blev viktiga ledord för socialtjänstens arbete (Lundström, 1996). I och med socialtjänstlagstiftningens införande utrycktes en tilltro till människors egen förmåga att påverka sin situation. Det gjordes genom att fokusera på stöd till individer för att ge dem förutsättningar att utveckla sina egna resurser (Thunved, 2012). En annan stor skillnad var att det endast var möjligt att motivera insatser och åtgärder med hänvisning till barnet eller 
familjens egna behov (Börjeson, 2010). Därmed handlade det inte längre om att skydda samhället. Att det fortfarande gavs möjlighet att omhänderta barn kan tolkas som att socialtjänstens kontrollerande funktion blev kvar (Lundström, 1996).

\subsection{Socialtjänstens barnavårdsutredningar i början av 2000-talet - kontextuella förutsättningar}

Socialtjänstlagen har justerats vid ett flertal tillfällen efter införandet 1982 och i början av 2000-talet reglerar den senaste versionen av socialtjänstlagen (SoL) från 2001 (2001:453) socialtjänstens arbete. Även därefter har dock lagen ändrats flera gånger, så också under avhandlingsarbetets genomförande.

Socialtjänstens barnavårdsutredningar regleras därmed av socialtjänstlagen men det finns även styrande bestämmelser för barnavårdsutredningarnas genomförande i andra lagar, samt i Socialstyrelsens föreskrifter. Riktlinjer ges även i Socialstyrelsens allmänna råd och handböcker. Övergripande regleras socialtjänstens ansvar i barnavårdsärenden även i vissa internationella konventioner, där särskilt FN:s konvention om barnets rättigheter (Barnkonventionen) är en av dem.

\subsubsection{Barnkonventionens ratificering}

Barnkonventionen fastslår alla barns rättigheter och ger därigenom förutsättningar för att skapa ett samhälle som utgår från ett tydligt barnrättsperspektiv (Barnombudsmannen (BO), 1999; Prop 2012/13:10). Sedan Sverige 1990 ratificerade Barnkonventionen har den svenska lagstiftningen ändrats på flera områden för att stämma överens med de åtaganden som anges $\mathrm{i}$ konventionen. Även om domstolarna i Sverige inte är direkt bundna av Barnkonventionen på samma sätt som av svensk lagstiftning ska dess principer genomsyra de verksamheter som bedrivs både nationellt, regionalt och lokalt (Socialstyrelsen, 2006d). Domstolar och förvaltningsmyndigheter så som socialtjänsten ska också alltid tolka och tillämpa nationell rätt i linje med Barnkonventionen (Bernitz \& Kjellgren, 2010). Barnkonventionens artiklar har därmed påverkat de riktlinjer som finns för hur socialtjänstens barnavårdsutredningar ska genomföras men även för hur barns hälsa ska uppmärksammas.

Konventionen har fyra grundläggande principer som kommer till uttryck i konventionens artiklar 2, 3, 6 och 12. I dessa anges att alla barn har lika värde och barn är lika mycket värda som vuxna (Art. 2), att barns bästa ska komma i främsta rummet i alla åtgärder som rör dem (Art. 3), att varje barn har rätt till liv, överlevnad och utveckling (Art. 6) samt att barn har rätt att uttrycka sina åsikter i alla frågor som berör dem. Barnets åsikter ska också få betydelse, dock beroende av deras ålder och mognad (Art. 12). Förutom att de har självständig betydelse ska de dessutom prägla tolkning och tillämpning av konventionens övriga artiklar (Leviner, 2011; Utrikesdepartementet [UD], 2006).

Konventionen anger också att barn har rätt till den levnadsstandard som krävs för de ska kunna utvecklas fysiskt, psykiskt, andligt, moraliskt och socialt. Föräldrar eller andra som är ansvariga för barnet anses ha huvudansvaret för att säkerställa de levnadsvillkor som är nödvändiga för barnets utveckling (Art. 27). I Barnkonventionen finns också ett specifikt erkännande av alla barns rätt till en god hälsa. I artikel 24 nämns, exempelvis, att barn har rätt att få nödvändig information för att uppnå god hälsa men också rätten till sjukvård och 
rehabilitering (Art. 24). Då barn är omhändertagna på grund av brister i omvårdnad eller som skydd för sin psykiska eller fysiska hälsa nämns även att omständigheter som rör barnets omhändertagande regelbundet ska följas upp (Art. 25) (UD, 2006).

\subsubsection{Barnsyn i den rättsliga regleringen}

Vägledande för socialtjänstens arbete med barn och unga är bestämmelser i nationell lagstiftning som anger vad barn har för rättigheter. Här kan exempelvis föräldrabalken (FB) (1949:381) nämnas. Där anges att barn har rätt till omvårdnad, trygghet och god fostran.

Dessutom fastställs att barn ska behandlas med respekt för sin person och inte får utsättas för kroppslig bestraffning eller annan kränkande behandling (FB 6:1).

Socialtjänstlagen (2001:453) som mer specifikt reglerar socialtjänstens arbete är en ramlag, vilket innebär att den främst innehåller allmänna mål, riktlinjer och ansvarsområden. Socialtjänsten ges därigenom ett relativt stort eget utrymme att bestämma hur barnärenden ska hanteras (Thunved, 2012). Vikten av att tillvarata individens egna resurser, att insatser ska utformas och genomföras tillsammans med den individ som berörs, samt att hänsyn ska tas till individens integritet och självbestämmande är dock ledord inskrivna $i$ en av socialtjänstlagens portalparagrafer och ska därmed vara vägledande för allt socialt barnavårdsarbete (SoL 1:1).

Bestämmelser som handlar om socialtjänstens ansvar och arbete med barn definierar individer upp till 18 års ålder som barn (SoL 1:2). Det framkommer att socialtjänsten har ansvar för att barn växer upp under trygga och goda förhållanden. De ska i samarbete med föräldrarna se till att barn utvecklas i positiv riktning, både fysiskt och socialt. Om det anses motiverat utifrån barns bästa så har socialtjänsten även ansvar för att barn får vård och fostran utanför det egna hemmet. Socialtjänsten ska också förebygga och motverka missbruk hos barn (SoL 5:1). I socialtjänstlagens första kapitel (SoL 1: 2) finns sedan 1997 även inskrivet att hänsyn ska tas till barnets bästa vid åtgärder som rör barn (Lag 1997:313).

Dessutom framgår både i Socialstyrelsen förarbeten och i riktlinjer att socialsekreterare ska utgå ifrån ett barnperspektiv (Prop.2012/13:10; Socialstyrelsen, 1997; 2006d; 2010). Det anges att socialtjänstens verksamhet både ska lyssna till barns egna synpunkter men också ta ansvar för att tillvarata barns villkor. Dessutom ska verksamheten uppmärksamma vilka konsekvenser olika beslut kan få med utgångspunkt i barns behov och barns bästa (Prop.2012/13:10; Socialstyrelsen, 1997; Thunved, 2012).

I socialtjänstlagen anges mer specifikt att barn, när en åtgärd rör dem, ska få relevant information och de ska också ges möjlighet att framföra sina åsikter (SoL 11:10). Socialstyrelsen rekommenderar att socialsekreterare träffar barnet, både enskilt och tillsammans med föräldrarna under en utredning (Socialstyrelsen, 2006b, 2006c). Beroende på barnets ålder och mognad ska socialsekreterare även ta hänsyn till barnets åsikter och inställning vid en utredning. Att barnet ska $f a ̊$ information om en åtgärd som rör dem är något som tydliggjordes i lagen under 2008. Socialtjänsten har sedan 2010 också möjlighet att prata med barn utan vårdnadshavares samtycke samt utan att de är närvarande vid en utredning om behov av ingripande till ett barns skydd eller stöd (SoL 11:10). En ytterligare förändring som trädde i kraft 1 januari 2013 är att även om barn inte framför sina åsikter, så ska socialsekreterare belysa hans eller hennes inställning så långt det är möjligt (SoL 11:10). Från 15 års ålder har barn rätt att själva föra sin talan i mål och ärenden. Det poängteras dock att 
även yngre barn bör höras i domstol, om barnet inte kan antas ta skada av det (SoL 11:10). Tidigare formulering om att yngre barn bör höras om det kan vara till nytta för utredningen har därmed tagits bort.

Förutom att barn ska $f a ̊$ information och ges möjlighet att ge information kan barns delaktighet $\mathrm{i}$ utredningsarbetet även handla om att de ges möjlighet att kommentera andras synpunkter, att de blir inbjudna till möten och att de ges valmöjligheter i beslut som rör dem (Socialstyrelsen, 2006b). Socialstyrelsen poängterar samtidigt att det i slutänden alltid är vuxna som måste fatta beslut om vad som är barnets bästa (Prop. 1996/97:124). Det innebär att det finns ett utrymme för socialsekreterare att på olika sätt tolka och förstå hur barn ska göras delaktiga samt synliggöras i socialtjänstens utredningar.

\subsubsection{Socialnämndens övergripande utredningsansvar}

Ansvarig för genomförandet av barnavårdsutredningar är socialnämnden i respektive kommun. Nämndledamöter i socialnämnden är förtroendevalda politiker som har en plats i kommunfullmäktige. Där avgörs vilka nämndemän som ska ansvara för och fatta beslut $i$ socialnämnden (Kommunallag (1991:900) 3:3). Det finns inte någon särskild kompetensbeskrivning för nämndemän i socialnämnden förutom de krav som ställs för att få sitta i kommunfullmäktige (Kommunallag 4:5). Däremot anges i socialtjänstlagen att personal inom socialnämndernas praktiska verksamheter (dvs. socialtjänsten) ska ha lämplig utbildning och erfarenhet (SoL 3:3) för att genomföra ett utredningsarbete. Socialstyrelsen uttalar dessutom att de som ska handlägga utredningar bör ha socionomexamen och minst ett års yrkeserfarenhet inom socialt arbete. De anger också att personalen bör ha teoretiska och praktiska kunskaper om barn och ungas utveckling och behov, samtal och relationer, samverkan, regelverk och rättsutveckling samt insatser (Socialstyrelsen, 2006c).

Socialnämnden har en lagstadgad skyldighet att inleda en utredning så snart de får kännedom om att ett barn kan leva under omständigheter som kan leda till att socialnämnden enligt lag måste ingripa (SoL 11: 1). I socialtjänstlagen betonas vikten av att alla som får kännedom om att ett barn far illa bör göra en anmälan till socialtjänsten. Verksamheter inom exempelvis hälso- och sjukvård, rättspsykiatrisk undersökningsverksamhet, socialtjänst och kriminalvård är skyldiga att göra en anmälan och lämna information till socialtjänsten om de får kännedom om något som kan innebära att ett barn behöver stöd och skydd (SoL 14:1). Förutom i situationer när anmälningar om oro för barn inkommer till socialtjänsten kan myndigheten också inleda utredning när familjer ansöker om stöd för att förbättra sina livssituationer (Socialstyrelsen, 2006b). Innan en utredning påbörjas gör socialtjänsten en förhandsgranskning av uppgifterna som inkommit och bedömer om ärendet kommer att kunna leda till någon åtgärd. En utredning ska därför inte påbörjas om det från början bedöms att nämnden inte kommer att vidta några åtgärder (Prop. 1979/80:1). En förhandsbedömning bör göras inom 14 dagar från att socialtjänsten fått in en anmälan eller ansökan (Prop 2012/2013; SoL 11:1).

\subsubsection{Genomförande av barnavårdsutredningar}

Genomförandet av en barnavårdsutredning görs med syftet att införskaffa ett underlag för att kunna bedöma barns behov och föräldrars förmåga att tillgodose behoven. Den information som samlas in ska belysa barns och familjers situation utifrån både styrkor och svagheter 
(Socialstyrelsen, 2004). Om ett barn bedöms ha behov av stöd eller skydd ska utredningen dessutom presentera ett förslag om insats (Socialstyrelsen, 2006d). För att kunna bedöma ett barns behov av stöd och skydd får utföraren under utredningen ta kontakt med både professionella och andra som bedöms ha viktig information att tillföra. Utredningens genomförande bör dock inte leda till att någon utsätts för onödig skada eller fara. Utredningen får inte heller pågå i mer än fyra månader från att den inleds och den bör inte bli mer omfattande än vad som är nödvändigt utifrån det specifika ärendets omständigheter (SoL $11: 2)$.

I socialtjänstlagen finns inte några tydliga riktlinjer om vilken typ av kunskap som kan vara viktig för att kunna bedöma barns livssituation även om det finns övergripande hänvisningar till barns utveckling och hälsa som viktiga faktorer att förhålla sig till. Det framkommer i lagtext att Socialnämnden ska arbeta för att barn utvecklas gynnsamt både fysiskt och socialt (SoL 5:1). Socialnämndens uppgift att göra en bedömning av barns hälsa och utveckling uppmärksammas även i lagen (1990:52) om särskilda bestämmelser av vård av unga (LVU).

\subsubsection{Dokumentation}

Dokumentationen under en barnavårdsutredning kan utifrån ett rättssäkerhetsperspektiv vara av betydelse då den tydliggör vilken information som använts i ett ärende (Socialstyrelsen, 2006b). Dokumentationen ska klargöra vilka beslut som fattats och vilka åtgärder som föreslagits men även andra omständigheter och händelser som anses ha betydelse för ärendehanteringen. Finns det brister i dokumentationen innebär det en risk att beslut kan fattas på otillräckliga eller felaktiga grunder (Prop. 2004/05:39).

Dokumentationen är dessutom en förutsättning för att både barn och vårdnadshavare ska kunna förstå och kontrollera vad socialtjänsten efter avslutad utredning grundat sina beslut på (Leviner \& Eneroth, 2012) och en förutsättning för att senare kunna följa upp om barnet fått det stöd som det har beslutats om (Prop. 2004/05:39).

De uppgifter som dokumenteras ska vara korrekta och det ska framgå vem informationen kommer ifrån. Om det framkommer information som anses viktig men sanningshalten är tveksam så ska dessa uppgifter ändå dokumenteras och säkerheten anges (Prop. 1996/97:124; Socialstyrelsen, 2006e). Dokumentationen ska göras med respekt för individen som det handlar om och denne ska löpande hållas informerad om ärendet och de uppgifter som inhämtas och dokumenteras. Vid en eventuell konflikt mellan vad som anses viktigt att anteckna och individens integritet ska uppgifter av betydelse för socialtjänstens bedömningar och beslut dokumenteras. Värdeomdömen får dock inte förekomma (Leviner \& Eneroth, 2012). Det ska också dokumenteras om personen som utredningen handlar om anser att någon uppgift inte stämmer med hans eller hennes uppfattning (SoL 11:6; Socialstyrelsen, 2010). Här görs inte någon åtskillnad på barn och vuxna.

Socialstyrelsen menar därmed att det är viktigt att de inblandade personerna kan känna igen sina berättelser och att händelser och situationer är beskrivna på ett sakligt, korrekt samt respektfullt sätt med tanke på att barnavårdsutredningar kan innehålla en väsentlig del av ett barns livshistoria. Utredningen ska kunna läsas och förstås, såväl när utredningen är aktuell som vid ett senare tillfälle i livet (Socialstyrelsen, 2004). 
Det här innebär att utredningsdokumentet bör ha en tydlig struktur och uppgifter av betydelse för att kunna fatta ett välgrundat beslut behöver dokumenteras och framgå i beslutsmotiveringen. Barnavårdsutredningar kan därför ha varierande längd och redovisa olika antal informationsskällor. Dokumentationen ska anpassas till mottagaren vilket innebär ett förhållningssätt som kan inkludera ett flertal mottagare med olika förkunskaper och intressen $\mathrm{i}$ ärendet. Barn som är över 15 år har rätt att ta del av det som står $\mathrm{i}$ utredningsmaterialet men det kan även vara viktigt att yngre barn, beroende på ålder och mognad, direkt får ta del av det som har dokumenterats. Utredningen ska även kunna läsas av föräldrar, politiker i utskott eller socialnämnd samt jurister och nämndemän i domstol (Socialstyrelsen, 2006b; 2006d).

\subsubsection{Bedömningar och beslut om insatser}

I bedömningar av barns livssituation ska den information som framkommit under utredningen sammanvägas. Såväl problem som resurser ska lyftas fram. Tydliga slutsatser om barns behov och hur dessa bäst kan tillgodoses bör formuleras. Socialstyrelsen betonar att det vid argumentationen för ett beslut ska framgå hur socialtjänsten tagit hänsyn till barnets bästa (Socialstyrelsen 2006c).

De insatser som en individ erbjuds presenteras i socialtjänstlagen som en rättighet när personen inte själv har möjlighet att på annat sätt tillgodose sina behov (SoL 4:1). Stöd från socialnämnden kan därmed ses som frivilligt men när det gäller barn är de beroende av vad föräldrarna anser då de i sin roll som vårdnadshavare måste ge sitt samtycke till insatser. Ett undantag ifrån detta finns för barn över 15 år då beslut om stöd av kontaktperson endast kan fattas om barnet själv begärt eller samtycker till det (SoL 3:6). Även om vårdnadshavare måste ge sitt samtycke till insatser har socialnämnden också fortfarande möjlighet att ingripa med tvång om de anser att vårdnadshavare allvarligt brister i sin omsorgsförmåga eller om barn själva har ett destruktivt beteende som innebär en påtaglig fara för barnets hälsa och utveckling (LVU 2- $3 \S \S$ ).

Det anges både i socialtjänstlagen och i rekommendationer från Socialstyrelsen att socialsekreterare ska göra bedömningar av barns nuvarande utsatthet och av den potentiella risk som finns för negativ utveckling i framtiden. Socialnämnden förväntas se till att barn och ungdomar som riskerar att utvecklas ogynnsamt får det skydd och stöd som de behöver (SoL 5:1). Detta ytterst genom ingripanden med stöd av LVU om det genom en riskbedömning framgår att det finns en påtaglig risk för ett barns utveckling och hälsa, antingen på grund av hemmiljön ( $2 \S)$ eller barnets egna destruktiva beteende ( $3 \S)$. Trots de relativt omfattande bestämmelser som redogjorts för ovan avseende handläggning av barnavårdsärenden finns dock få konkreta formuleringar om hur ett barns situation ska bedömas.

\subsubsection{Utredningsarbetets teoretiska utgångspunkt}

\subsubsection{Systemteori}

Enligt Socialstyrelsens rekommendation ska det övergripande teoretiska perspektivet i socialtjänstens utredningsarbete med barn utgå från Urie Bronfenbrenners (1979) bioekologiska modell vilket innebär ett systemteoretiskt förhållningssätt. Denna teoretiska ansats beskrivs i riktlinjer från Socialstyrelsen (Socialstyrelsen 2006a, 2006b). Där 
framkommer att den bioekologiska modellen medför en sociokulturell syn där både det individuella barnets sociala och emotionella resurser men också det sociala system som barnet ingår i kan påverka individers utveckling. Att uppmärksamma både individen och det sociala systemet blir därmed betydelsefullt för att kunna förstå ett barns situation, behov och utveckling. Barns utveckling ska också förstås som varande i en process i och med att den påverkas av vad som händer över tid men dessutom av hur ofta och med vilken intensitet något sker. Bronfenbrenners modell beskriver fem sociala system som omger individen och som påverkar barns utveckling. Dessa är mikro, meso-, exo, makro- och chronosystemet (Bronfenbrenner, 1979, 1999; Meadows, 2010).

Mikrosystemet består av barns närmaste omgivning så som familj, skola, vänner, fritidsintressen och eventuella läkarkontakter (Bronfenbrenner, 1979). Därmed är barns relationer och aktiviteter tillsammans med andra människor, exempelvis föräldrars syn på barns eventuella svårigheter, diagnos, eller funktionsnedsättning av betydelse för barns utveckling. Även barns relationer till andra barn påverkar barns livssituation, hälsa och utveckling.

Mesosystemet innefattar relationer mellan delar av mikrosystemet (Bronfenbrenner, 1979). Det kan exempelvis handla om barns erfarenheter från skola eller förskola och hur dessa påverkar barns samspel med familjen och tvärtom.

Exosystemet handlar om att barn kan påverkas av sociala sammanhang som de själva inte har en aktiv del i (Bronfenbrenner, 1979). Det kan exempelvis handla om föräldrarnas arbete men också barns tillgång till barnomsorg, skola, olika bidragssystem, hälso- och sjukvård. Det vill säga politiska beslut och satsningar ger förutsättningar och kan få konsekvenser för unika barns liv.

Makrosystemet inkluderar attityder och ideologier i den kultur som barnet lever i (Bronfenbrenner, 1979). Det innebär att både regleringar som gäller generellt men också lagar som specifikt riktar sig mot personer med speciella behov kan påverka barn. Dessutom har normer och värderingar om exempelvis, sociala problem, funktionshinder, sjukdom eller diagnoser betydelse för barns utveckling och hälsa.

Chronosystemet som i efterhand inkluderats i den ursprungliga modellen handlar om den temporala betydelsen för barns utveckling. Med det menas när något skett och under hur lång tid något som kan ha påverkat både barnet och det system som omger honom eller henne pågått (Bronfenbrenner \& Ceci, 1994; Meadows, 2010).

Det systemteoretiska perspektiv som är grunden i den bioekologiska modellen kan således bidra med förståelse för hur barns interaktion med omgivande sociala system påverkar deras fysiska och psykiska hälsa samt utveckling. Det kan dock vara nödvändigt att komplettera den systemteoretiska förståelseramen med andra teorier för att fullt ut förstå en individs livssituation (Payne, 2008). I riktlinjer för socialtjänstens utredningsarbete av barn och unga nämns att den systemteoretiska modellen ska kompletteras med teorier om barns identitetsutveckling, risk- och skyddsfaktorer, sårbarhet och motståndskraft samt anknytning (Socialstyrelsen, 2006a, 2006b). 


\subsubsection{Utvecklingspsykologiska teorier}

Förutom ovan nämnda teorier uppmärksammar Socialstyrelsen dessutom betydelsen av barns utveckling utifrån utvecklingspsykologisk stadieteori. Här nämns att barns viktigaste utvecklingsuppgift under det första levnadsåret är att knyta an till föräldrarna eller andra personer som har vårdnaden om dem. Utvecklingen av kognitiva, språkliga och fysiska färdigheter beskrivs som betydelsefulla under framförallt de första åren av barns liv och den sociala utvecklingen anses få en mer framträdande roll under den senare delen av barnaåren. För små barn framkommer synsättet att de tar skada av omsorgssvikt, då sådant bemötande kan påverka förmågan att utvecklas på ett för åldern adekvat sätt. Det noteras dock att barn inte behöver påverkas negativt trots försummelse från föräldrarnas sida. Detta anses kunna bero på barnets individuella egenskaper, dess relationer till andra vuxna samt skyddande miljöer som skolan, fritidsaktiviteter eller grannskap. Då tonåringars utveckling beskrivs nämns den sociala och känslomässiga frigörelsen som viktig. Det poängteras också att tonåringar på grund av sitt eget beteende kan utsätta sig för situationer som kan leda till att de blir traumatiserade. Socialstyrelsen menar dessutom att barn som har det svårt vanligtvis uttrycker det på något sätt vilket kan komma fram i noggrant genomförda utredningar. För att kunna bedöma om barn är i behov av stöd, menar Socialstyrelsen, att socialsekreterare behöver kunskap om barns utveckling i relation till ålder och mognad men också en förståelse för att det unika barnets utvecklingsförlopp kan variera i förhållande till dess förutsättningar (Socialstyrelsen, 2006b).

\subsubsection{Utredningsarbetets organisatoriska förutsättningar}

Förutom att den rättsliga regleringen har inflytande på socialsekreterares utredningsarbete så påverkas de också av den specifika organisation som de arbetar i (Blom, 1998; Lundström, 1993; Meeuwisse, Sunesson, \& Swärd, 2006; Östberg, 2010). Organisationen av utredningsarbetet innebär, exempelvis, att ledningen på lokal nivå förmedlar rutiner och strukturer som socialsekreterare måste förhålla sig till (Blom, 1998; Östberg, 2010).

Dessutom kan kollegor ha synpunkter på vilket språk och vilka handlingar som är möjliga och normativt lämpliga (Blom, 1998, 2006). Dessa skapade strukturer kan då bli normerande för hur genomförandet av en barnavårdsutredning bör gå till och vilket förhållningssätt till barn som ska råda.

\subsubsection{Handläggnings- och dokumentationssystemet Barns Behov i Centrum (BBIC)}

Socialstyrelsen bestämde 2006 att socialtjänsten i Sverige skulle införa ett nytt handläggningoch dokumentationssystem, Barns Behov i Centrum (BBIC). Beslutet tillkom på grund av kritik mot socialtjänstens bristfälliga dokumentation i barnavårdsärenden och handläggningens varierande kvalitet (Socialstyrelsen, 2000). BBIC bygger på ett system som från början utvecklades av socialtjänsten i England, Integrated Children's System (ICS), (Cleaver m. fl., 2008; Parker Ward, Jackson, Aldgate \& Wedge, 1991) och som har anpassats till svenska förhållanden. Utifrån det övergripande målet att alla barn ska ha liknande förutsättningar i socialtjänstens utredningsarbete och beslutade insatser så var syftet med införandet av BBIC att skapa struktur och systematik i processer och dokumentation (Socialstyrelsen, 2006a, 2008). Socialstyrelsen förordar att socialtjänsten ska utgå från BBIC i sin handläggning och dokumentation men kommunerna måste uppfylla vissa krav för att få 
en så kallad BBIC- licens med rättighet att använda modellen. År 2012 uppgav $62 \%$ av landets kommuner att de utgick ifrån ovan nämnda modell (www.socialstyrelsen.se).

\subsubsection{Handläggning utifrån BBIC}

När barnavårdsutredningar genomförs utifrån BBIC är det bestämmelser i socialtjänstlagen och övergripande nationella riktlinjer för handläggning och dokumentation som gäller. Socialstyrelsen anger dock specifika direktiv för hur socialsekreterare ska utreda och dokumentera när de gör barnavårdsutredningar utifrån detta system.

Några av direktiven för utredningar enligt BBIC presenteras i form av en triangel (se nedan). Triangeln ska ge vägledning i vilken information som ska samlas in under en utredning och hur denna sedan ska analyseras. De tre sidorna i triangeln representerar barnets behov, föräldrarnas förmågor att tillgodose behoven samt hur andra omgivande faktorer påverkar barns utveckling. Utgångspunkten är att barn har behov som måste tillgodoses för att de ska kunna få en gynnsam utveckling. Utredningen ska klargöra om föräldrarna har förmåga att tillgodose behoven och hur föräldrarnas eventuella problematik påverkar barnet. Dessutom anses familje- och miljöfaktorer påverka såväl barns utveckling som vårdnadshavarnas möjligheter att tillgodose deras behov vilket därför också måste tas i beaktande i en utredning. De sju behovsområden i barns liv som presenteras som särskilt viktiga att uppmärksamma är: hälsa, känslomässig- och beteendemässig utveckling, utbildning, identitet, familj- och sociala relationer, socialt uppträdande samt förmåga att klara sig själv.

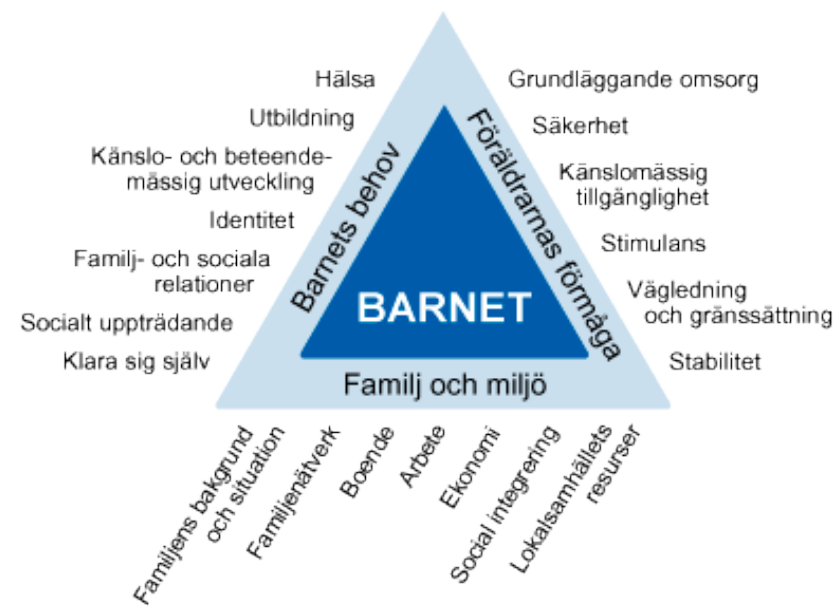

(Socialstyrelsen, 2006a)

För utredningar enligt BBIC systemet finns också fördjupningsdokument som anger vilken information som kan ge fördjupad kunskap inom de sju behovsområdena. I fördjupningsdokumentet om hälsa poängteras vikten av att synliggöra både fysisk och psykisk hälsa. Anledningen till detta är det starka samband som anses finnas mellan en problematisk social och ekonomisk uppväxtmiljö och ohälsa. I dessa dokument uppges att allt 
från sjukdomar, preventiv hälsovård och funktionsnedsättningar till diet, motion och hälsorisker är relevant att uppmärksamma. Information om akuta, återkommande och kroniska sjukdomar, skador efter olycksfall, medicinering eller annan behandling anses också vara av betydelse. Några av de hälsoaspekter som ska uppmärksammas i alla åldersgrupper är längd, vikt, syn, hörsel, vaccinationer och hälsokontroller. Upp till tio års ålder anses det väsentligt att få fram information om barns fin- och grovmotorik. Tandvård bör uppmärksammas från tre års ålder. Från 11 års ålder bör barnets eventuella missbruk av alkohol och andra droger samt sexuellt riskbeteende uppmärksammas då dessa aspekter förstås som specifika hälsorisker. I fördjupningsdokumentet om känslo- och beteendemässig utveckling poängteras dessutom att barns sinnesstämning, känslouttryck, temperament och symptom på oro och ängslan bör observeras. Socialsekreterare uppmanas också att synliggöra barns eventuella utsatthet genom upplevelser från andra personer i dess närhet (Socialstyrelsen, 2008).

I utredningsmallen för BBIC anges också direktiv för läkarundersökningar av barn. Syftet med undersökningen är att identifiera både nuvarande och tidigare försummade hälsooch sjukvårdsbehov. Det förordas att läkarundersökningen ska karaktäriseras av en helhetssyn på barnets livssituation. Det nämns också att det kan finnas behov av två undersökningar där den första syftar till att få en uppfattning om aktuella hälso- och sjukvårdsbehov och den andra en fördjupad förståelse för barns vårdbehov. Dessutom uppges att det kan vara aktuellt att inhämta tidigare sjukvårdsjournaler, intyg och medicinska utlåtanden (Socialstyrelsen, 2009a).

Det finns även direktiv för hur dokumentationen ska struktureras. En grundregel är att socialsekreteraren förväntas skriva kortfattat och skilja på fakta, olika informationskällor, värderingar och personliga ståndpunkter. Utredningsmallen innehåller dessutom olika kolumner där åsikter från barnet, föräldrarna, övriga personer samt socialsekreterares iakttagelser kan presenteras separat. Barns uppfattningar om sig själva och sin situation förväntas därigenom återges precis som andra personers uppfattningar. Det saknas emellertid en mer specifik vägledning för hur dokumentation av slutliga bedömningar i utredningarna bör formuleras (Socialstyrelsen, 2009b). 


\section{Tidigare forskning}

\subsection{Fysisk och psykisk hälsa hos barn i socialtjänstens verksamhet}

Utifrån ett internationellt perspektiv har svenska barn god hälsa. Spädbarnsdödligheten är, exempelvis, en av de lägsta i världen och hälsoutvecklingen för barn upp till 15 år har överlag varit positiv under den senaste 20 årsperioden (Statens Folkhälsoinstitut, 2011a). Samtidigt finns det individuella hälsoskillnader bland barn i Sverige och barn i socialt utsatta miljöer har visat sig löpa en större risk för ohälsa. Den förebyggande hälsovården når inte heller dessa utsatta barn i samma utsträckning som andra barn (Socialstyrelen, 2013b).

Att det i Sverige förs begränsad statistik över socialtjänstens barnavård (Sundell, Vinnerljung, Andrée Löfholm \& Humlesjö, 2004; Wiklund, 2008) medför dock att det övergripande kunskapsläget om den fysiska och psykiska hälsan hos barn som kommer i kontakt med socialtjänsten är begränsad. Det har också visat sig att samverkan mellan socialtjänsten och andra verksamheter där barn kan få stöd och hjälp för sin hälsa inte är en självklarhet, även om 69 procent av landets kommuner har överenskommelser om att de ska samverka med barn- och ungdomspsykiatrin och 60 procent har kommit överens om samverkan med barnhälsovården (Socialstyrelsen, 2013b).

Tidigare studier visar att barn som utreds av socialtjänsten kan leva i en social situation där de exponeras för en mängd olika faktorer som kan inverka negativt på deras hälsa och utveckling (McAuley \& Davis, 2009; McLeod \& Bywaters, 2000; Socialstyrelsen, 2000, 2006a; Sundell m. fl., 2004). Barn som utreds inom socialtjänsten är exempelvis barn som växer upp i dysfunktionella familjer (Eriksson, 2012; Hollander 2001), som lever med föräldrar som använder droger (Andersson, 2001; Grant m. fl., 2011), misshandlar dem fysiskt eller utnyttjar dem sexuellt (Lindell \& Svedin, 2004). Det finns också barn som riskerar negativ hälsoutveckling på grund av fysiska och psykologiska svårigheter (Guglani, Rushton \& Ford, 2008; McCann, James, Wilson \& Dunn, 1996; McCue Horwitz m. fl., 2012), en problematisk skolgång (Johnson-Reid m. fl., 2007; Sundell m fl., 2004; Östberg, 2010) eller att de har ett drogberoende (Wiklund, 2006). Internationella studier visar dessutom att barn som har kontakt med socialtjänsten tenderer att ha sämre psykisk hälsa i jämförelse med andra barn (Ford, Vostanis, Meltzer \& Goodman, 2007; Guglani m. fl., 2008; McCann m. fl., 1996; Parker m. fl., 1991)

Tidigare forskning och rapporter om socialtjänstens arbete och barns hälsa utgår dock framförallt från barn som omhändertagits av socialtjänsten. Där har det framkommit att barn redan inför en placering kan ha haft en problematisk fysisk och psykisk hälsa (Socialstyrelsen, 2013a). Nationella och internationella studier visar dessutom att barn som är omhändertagna av socialtjänsten har sämre psykisk hälsa i jämförelse med jämnåriga som inte varit placerade (McAuley \& Davis, 2009; Socialstyrelsen 2013b; Vinnerljung m. fl., 2006). Placerade barn använder också betydligt mer psykofarmaka än andra barn i samma ålder. Det är speciellt vanligt bland barn som är över 11 år, men också yngre barn kan använda psykofarmaka så som ångestdämpande medicin och sömnmedel. Placerade barn behandlas också med psykofarmaka utan psykiatrisk diagnos i större utsträckning än andra jämnåriga. Dessutom löper placerade barn större risk för att använda psykofarmaka även som vuxna (Socialstyrelsen, 2013b) och många barn har hälsoproblem även efter att placeringen är avslutad (Dixon, 2008; Hill \& Thomson, 2003; Kristofersen, 2005; McCann m. fl., 1996; 
Parker m. fl., 1991; Socialsstyrelsen, 2000, 2006a; Sundell m. fl., 2004; Takayama, Wolfe \& Coulter, 1998; Vinnerljung, 2006; Vinnerljung m.fl., 2006). En longitudinell studie av barn som i unga år var placerade på barnhem visar att de själva kan uppfatta att de har psykiska problem efteråt. Detta trots att deras liv efter placeringen i övrigt gestaltat sig på olika sätt (Andersson, 2003).

Risken för en negativ hälsoutveckling kan vara större ju mer omfattande socialtjänstens insatser har varit. Även vid jämförelser med barn som vuxit upp i liknande socioekonomiska och psykosociala miljöer så har barn som varit placerade större risk för negativ hälsoutveckling (Vinnerljung m. fl.,2006). Det här kan betyda att det finns brister i socialtjänstens medicinska omhändertagande av placerade barn. En undersökning inför införandet av handläggning- och dokumentationssystemet BBIC visade att 2/3 av 108 placerade barn (de flesta tonåringar) hade någon form av hälsoproblem. Flertalet av dessa hälsoproblem angavs av socialsekreterare vara nyupptäckta trots att många av barnen hade varit placerade i ett par år (Socialstyrelsen, 2000). Placerade barn kan själva uttrycka att de fått ta ett alltför stort ansvar för kontinuitet i den sjukvård de behöver (Socialstyrelsen, 2013a). Det har också framkommit att barn som varit placerade via socialtjänsten inte genomgått hälso-, syn- och hörselundersökningar i samma utsträckning som andra barn. Placerade barn kan dessutom sakna vaccinationer i högre utsträckning än andra barn och de har mer sällan gått på regelbundna besök hos tandläkare (Kling, 2010). Informationen i socialtjänstens akter för placerade barn kan också vara vag vad gäller deras fysiska och psykiska hälsa (Andersson, 2003; Kling, 2010). Det finns dessutom brister i beskrivningar av hälsoaspekter i socialtjänstens bedömningar av placerade barns behov av stöd och skydd. I de socialtjänstakter där det fanns omfattande medicinsk information saknades analyser av vilka eventuella konsekvenser hälsosituationen kunde få för barnen och om barnens medicinska behov var tillgodosedda. För de flesta barn som hade placerats enligt LVU fanns ett läkarintyg men vanligtvis innehöll de summariska beskrivningar av undersökningar som gav föga information om barnets fysiska och psykiska hälsa (Kling, 2010). En annan svensk studie visar att läkarundersökning på begäran av socialtjänsten endast genomförts vid ingripanden med stöd av LVU och inte när barn placerats frivilligt. Dessutom kan läkarundersökningar användas som ett komplement till ansökan om tvångsomhändertagande, istället för som en del i bedömningsunderlaget för att ge ytterligare ett perspektiv på barns livssituation vid beslut om barns behov av stöd och skydd (Leviner, 2011).

\subsection{Påverkansfaktorer för barns fysiska och psykiska hälsoutveckling}

Tidigare studier visar att hälsa kan vara en betydelsefull faktor både för det fysiska och psykiska välbefinnandet och hälsotillståndet kan dessutom vara avgörande för hur barns vardagsliv och sociala umgänge med andra fungerar (Halfon \& Hochstein, 2002). Det kan dessutom vara både biologiska, psykologiska, sociala, kulturella, och ekonomiska faktorer som påverkar ett barns fysiska och psykiska hälsoutveckling. De biologiska faktorer som är relevanta för ett barns hälsostatus är exempelvis den genetiska disposition som de ärvt från föräldrarna. Betydelsefull för deras hälsoutveckling är även det specifika barnets fysiologiska struktur och funktion, exempelvis organ, skelett och nervsystem samt hur dessa samverkar med varandra (Sarafino, 2006). Andra studier visar hur strukturella faktorer i samhället (Dahl 
m. fl., 2006; Kawachi, Subramanian \& Almeida- Filho, 2002) samt sociala och socioekonomiska faktorer i familjen och barns uppväxtmiljö påverkar barns hälsa (Bremberg, 1998; Berntsson \& Gustafsson, 2000; Eriksson \& Lindström, 2006; Gironda m. fl., 2006; Park m. fl., 2009; Robertson, Brunner \& Sheiham, 2006; Shaw, Dorling \& Smith, 2006; Socialdepartementet, 2004; Socialstyrelsen, 2000, 2006a, 2009c; Stansfeld, 2006; Statens Folkhälsoinstitut, 2011b; Steptoe, 2006; Sundelin, 1995; Voydanoff, 1990). Att barn som lever under utsatta förhållanden möter ett flertal faktorer som kan påverka deras hälsa och utveckling negativt har både nationella och internationella studier visat (Andersson, Ascher, Eastmond, 2010; Schumacher, Slep, Smith \& Heyman, 2001). Barn kan få psykologiska eller psykosociala problem om de utsätts för fysiska övergrepp, bevittnar våld mellan sina föräldrar eller växer upp i familjer där våld förekommer (Bolger \& Patterson, 2003; English, Marshall \& Steward, 2003; Pelcovitz, Kaplan, DeRosa, Mandel \& Salzinger, 2000). Disharmoni i hemmet tillsammans med våld har också visat sig kunna påverka hälsan negativt (Romans, Martin \& Mullen, 1995; Spaccarelli \& Kim, 1995). Sociala påverkansfaktorer för barns hälsoutveckling kan också förstås i relation till tidsaspekter. Upplevelser och erfarenheter i barndomen har visat sig kunna påverka barns hälsotillstånd senare i livet. Den tidpunkt i livet när en förändring av ett hälsotillstånd inträffar kan dessutom påverka effekterna av hälsoproblemets utveckling (Power \& Kuh, 2006). Därutöver kan en individs psykologiska resurser påverka förståelsen och hanteringen av ohälsa. Barns upplevelser och reaktion i en utsatt situation kan också påverka hur andra förstår risker för deras ohälsa. Detta kan i sin tur få konsekvenser för hur de agerar i förhållande till det aktuella barnet (Heinonen, Metteri \& Leach, 2009). På så sätt kan barns unika upplevelser av sin livssituation vara avgörande för andras förståelse av barnets fysiska och psykiska hälsa.

Förhållandet mellan psykisk och fysisk hälsa samt andra faktorer är komplicerat, då sociala faktorer kan påverka hälsan samtidigt som biologiska och psykologiska förutsättningar kan inverka på individens sociala förhållanden (Andershed, Andershed, \& Tuvblad, 2013; Lundberg, Åberg Yngwe, Kölegård Stjärne, Björk \& Fritzell, 2008). Det kan också vara så att fysiska funktionsnedsättningar påverkar psykiskt välmående (Garralda, 1994; Rangel, Garralda , Hall \& Woodham, 2003) samtidigt som psykologiska aspekter så som stress kan påverka kroppens fysiska reaktioner (Ljung \& Friberg, 1994). Psykiska problem ökar också risken för olycksfallsskador (Wan, Morabito, Khaw, Knudson \& Dicker, 2006).

\subsection{Risk- och skyddsbedömningar av barn}

Att bedöma risk kan vara komplicerat och tidigare studier har visat att riskers styrka kopplas till antalet närvarande ogynnsamma faktorer vid samma tillfälle men också till riskfaktorers intensitet och varaktighet. Antalet riskfaktorer har därmed större betydelse än att en speciell riskfaktor förekommer (Goodyer, 1995b). Riskfaktorer kan också ha utlösande eller vidmakthållande effekt. Utlösande faktorer är de som förorsakar att ett visst problem uppstår vid ett visst tillfälle. Vidmakthållande faktorer är faktorer som bidrar till att ett problem kvarstår (Andersson, 2008). En riskfaktor ska dessutom förstås i förhållande till barnets ålder och utvecklingsstadium då detta kan påverka utfallet av risken. Riskfaktorer kan också vara latenta vilket betyder att barn som utsätts för olika risker under sin uppväxt kan tyckas vara 
opåverkade men vid nästa svåra livshändelse kan en kraftig reaktion uppstå som kan förstås utifrån tidigare livshändelser (Goodyer, 1995b).

För att förstå riskfaktorer bör dessa dessutom förklaras i förhållande till skyddsfaktorer då dessa kan minska eller neutralisera risker. Skyddseffekten kan öka med antalet skyddsfaktorer men även skyddets varaktighet och intensitet har betydelse för skyddseffekten (Stattin \& Magnusson, 1996). Precis som för riskfaktorer kan utfallet av skyddsfaktorer handla om en samverkan mellan barnets individuella egenskaper, interaktionen med personer i deras närhet och den livssituation de befinner sig i (Rutter, 1990; Meadows, 2010). Hur barn själva agerar och hur andra personer reagerar i en viss situation får därmed betydelse för effekten av både risk- och skyddsfaktorer. Risk- och skyddsfaktorer kan därför påverka det enskilda barnet på varierande sätt (Rutter, 1990; Rutter \& Taylor, 2002). I och med denna variation uppstår det svårigheter att dra förenklade slutsatser om ett enskilt barns utsatthet för risk och därmed behov av stöd (Goodyer, 1995a; 1995b; Little, Axford \& Morpeth, 2004).

\subsection{Barns delaktighet i socialtjänstens barnavårdsutredningar}

\subsubsection{Barns rättigheter till deltaktighet}

Den rättsliga regleringen av socialtjänstens utredningsarbete lyfter fram att barn både har kunskaper och erfarenheter som är betydelsefulla när deras livssituation ska förstås. Rättssystemet är också tydligt i sitt budskap med att varje enskilt barn ska få komma till tals och få ge uttryck för sin vilja och inställning. Barn har också rätt till att få information om en åtgärd som rör dem samt ges möjligheter till delaktighet. Barns vilja ska också beaktas som en del i bedömningen av vad som är barns bästa (Leviner, 2011, 2012). Däremot har barn inte fullt ut rättigheter att självständigt tolka, agera och bestämma över sin livssituation (Aronsson, 2001b; Leviner, 2011; Mattsson, 2006). Så som lagstiftningen är formulerad finns det därmed en risk att föräldrars rätt går före barnens, till exempel i de fall där det finns en intressekonflikt mellan barn och föräldrar (Leviner, 2011). Vårdnadshavare har också rätt att bestämma vårdens innehåll och varaktighet då barn placeras frivilligt enligt socialtjänstlagen (Mattsson, 2006). Även om socialtjänsten sedan 2010 har möjlighet att föra samtal med barn utan vårdnadshavarens samtycke och utan vårdnadshavarens närvaro i vissa situationer (SoL11:10) så anses det viktigt att föräldrar får information om samtalet innan det genomförs. Föräldrar har därmed fortfarande möjlighet att påverka sina barn innan de samtalar med socialtjänsten (Leviner, 2011). Att föräldrar har stort inflytande på sina barns delaktighet i socialtjänstens utredningar kan förorsaka dilemman för socialsekreterare när de ska involvera barn i utredningsarbetet (Rasmusson, 2011).

Tidigare studier uppmärksammar också att Barnkonventionen och socialtjänstlagstiftningen i vissa fall kan uppfattas som vag i sina anvisningar om hur frågor som rör barn mer specifikt ska hanteras (Andersson \& Hollander, 1996; Kaldal, 2010; Leviner, 2011; Mattsson, 2006 ). Det framgår exempelvis inte hur ett samtal ska genomföras eller vem som ska prata med barnet. Inte heller preciseras på vilket sätt socialsekreterare ska ta hänsyn till barns ålder och mognad i bedömningen av vilken betydelse deras vilja ska få (Kaldal, 2010; Leviner, 2011). Barn som utreds har därmed begränsade möjligheter att 
påverka hur samtal med dem genomförs och hur de görs delaktiga. De har i princip inte heller rättslig möjlighet att påverka om och hur socialsekreterare skriver om deras livssituation i en utredning (Leviner, 2011).

\subsubsection{Inkludering av barn i socialtjänstens utredningsarbete}

Tidigare studier argumenterar för betydelsen av att inkludera barn i barnavårdsutredningar på grund av att barn kan ha uppfattningar som skiljer sig från socialsekreterare, föräldrar eller andra vuxna (Andersson, Aronsson, Hessle, Hollander \& Lundström, 2001; Gleason \& Evans, 2004; Hollander: 2001; Mason, 2008). Barn kan även uttrycka att de önskar vara delaktiga i socialtjänstens beslutsfattande om deras liv (Leeson, 2007; Mason, 2008). Att göra dem delaktiga kan dessutom innebära att de beslut som fattas i högre grad upplevs som relevanta för dem (Helm, 2011) och därigenom skapas förutsättningar för att ge stödinsatser som passar barnen. Dessutom kan inkludering av barn i beslutsfattanden innebära ett förbättrat välmående för dem (Vis, Strandbu, Holtan \& Thomas m. fl., 2010).

Kännetecknande för resultaten från tidigare studier är dock att barn inkluderas i socialtjänstens utredningsarbete i begränsad omfattning. Barn har exempelvis inte intervjuats om hur de upplever sin situation i samband med barnavårdsutredningar (Andersson, 2001; Cederborg \& Karlsson, 2001). I studier som handlar om familjerättsprocesser framkommer att socialsekreterare konsulterar barn och ger dem information men däremot ges inte barnen möjlighet att vara delaktiga i beslutsfattanden (Eriksson, 2012; Röbäck \& Höjer, 2009). Även om det över tid verkar ha blivit vanligare att socialsekreterare har en kontakt med barnet när barnavårdsutredningar genomförs (Sundell, Egelund, Andrée Löfholm \& Kaunitz, 2008) så kan finns det olika uppfattningar om vad barns delaktighet innebär. Barns upplevelser av huruvida de gjorts delaktiga eller ej kan skilja sig från socialsekreterarens uppfattningar (Gallagher, Smith, Mark \& Wilkinson m. fl., 2012; Mason 2008; Sundell m. fl., 2008). Handläggare inom socialtjänsten kan även sinsemellan ha olika föreställningar om delaktighet. Även om socialsekreterare kan uttrycka att barn bör bli lyssnade på så kan de ha olika intentioner med sina intervjuer beroende på barnets ålder och mognad. De kan också ha olika synsätt kring hur ofta, med vilket syfte samtal med barn ska genomföras under en utredning (Nybom, 2005). Det finns därmed variationer i hur barn görs delaktiga. Vissa socialsekreterare har enskilda samtal med barnen men ofta genomförs samtal tillsammans med en förälder (Cocozza, Gustafsson \& Sydsjö, 2006; Leviner, 2011).

Socialsekreterarens tillvägagångsätt vid intervjuer är dessutom av betydelse för barns delaktighet då kvaliteten på den intervjuteknik som används visat sig vara avgörande för barns möjligheter att kunna uttrycka sig och ge information om sin livssituation (Cederborg, 2010; Lamb \& Fauchier, 2001; Lamb, Hershkowitz, Sternberg, Boat \& Everson, 1996; Orbach \& Lamb, 1999, 2001). Detta kan i sin tur få konsekvenser för hur barns upplevelser kan gestaltas och inkluderas när bedömningar och beslut om deras livssituation ska formuleras (Cederborg, 2010).

\subsubsection{Synliggörande av barn i barnavårdsutredningar}

Socialsekreterare har det yttersta ansvaret för att tolka och analysera insamlad information samt formulera den skrivna texten i utredningen (Aronsson, 2001a; Börjeson, 2010; Hall, 1997; Hall, Slembrouck \& Sarangi, 2006). Hur barn synliggörs i en barnavårdsutredning är 
därmed beroende av hur socialsekreterare genomför dokumentationen (Aronsson, 2001a; Börjeson, 2010).

Även om barns livssituation och erfarenheter varierar har tidigare studier visat att socialtjänstens barnavårdsutredningar kan bygga på en likartad berättelsestruktur där liknande aspekter av livssituationen lyfts fram för alla barn. Swärd (1993) fann att så var fallet redan i mitten av 1900-talet men det har även konstaterats vid tillfällen därefter (Egelund, 1997; Hollander, 1985; Hydén, 1995). Konsekvensen av likartade berättelser innebär att beskrivningar inte alltid utgår ifrån det unika i enskilda individers situation, behov och önskemål (Järvinen, 2002; Ponnert, 2007; Swärd, 1993). Beskrivningar av individers upplevelser och uppfattningar kan i stället ha konstruerats för att passa socialtjänstens uppdrag (Roose, Mottart, Dejonckheere, van Nijnatten \& De Bie, 2009).

Internationella studier har också visat att barn kan vara mer eller mindre osynliggjorda i barnavårdsutredningarna. Beskrivningarna har istället handlat om föräldrars beteende och kapacitet (Holland, 2001, 2004; Kähkönen, 1999; Thomas \& Holland, 2010). När det gäller utredningar enligt handläggning- och dokumentationssystemet BBIC så finns det studier som visar att socialsekreterare, både i Sverige och i England, anser att den struktur som finns i BBIC kan öka möjligheten att fokusera på det specifika barnet vid dokumentationen (Cederborg, 2006; Horwath, 2011; Rasmusson, 2011). Samtidigt kan socialsekreterare uppleva att det finns svårigheter att förstå vilken typ av information som ska beskrivas under respektive behovsområde vilket kan innebära att barns behov inte synliggjorts även när denna utredningsmall använts (Horwath, 2011). När barns åsikter uppmärksammas följs dessa inte heller upp vid bedömningar (Rasmusson, 2004; Enell, 2009).

Informationen som framkommer om barn och deras livssituation $\mathrm{i}$ barnavårdsutredningar har i första hand givits av föräldrar (Egelund, 1997; Mattsson, 2002) och professionella (Hennum, 2011; Hydén, 1995) medan barns åsikter om sin livssituation kan saknas helt (Andersson m. fl., 2001; Hollander 1985; Thomas \& Holland, 2010). 


\section{Avhandlingsprojektet}

Syftet med den här avhandlingen är att utveckla och fördjupa kunskapen om hur socialtjänsten synliggör barns fysiska och psykiska hälsa samt barns uppfattningar i barnavårdsutredningar. De olika delstudierna belyser vilka aspekter av barns fysiska och psykiska hälsa som synliggörs i socialtjänstens utredningar och hur socialsekreterare resonerar kring barns hälsa i bedömningar av barns behov av stöd och skydd. Fokus är också på hur barns egna upplevelser av sin hälsa synliggörs i socialsekreterares argumentation för beslut samt hur barns uppfattningar om sig själva och sin livssituation lyfts fram i utredningar där det initialt finns en oro för deras fysiska eller psykiska hälsa.

\subsection{Perspektiv och teoretiska ansatser}

\subsubsection{Barnperspektiv}

Begreppet barnperspektiv har en central betydelse i analysen av hur barns fysiska och psykiska hälsa samt barns upplevelser uppmärksammas i barnavårdsutredningar.

Barnperspektiv är dock inte ett entydigt begrepp då betydelsen är kontextuellt bunden (Andersson \& Rasmusson, 2006; Aronsson, 2001a, 2012; Rasmusson, 2011). I denna avhandling riktas uppmärksamhet både mot betydelsen barns perspektiv och mot betydelsen perspektiv på barn (Andersson m. fl., 2001). Ett perspektiv på barn handlar om hur vuxna tar hänsyn till barns villkor, barns behov och barns bästa, i exempelvis politiska beslut eller i andra institutionella verksamheter i samhället. Barns perspektiv handlar om barns egna upplevelser och erfarenheter om sig själva och sin situation (Aronsson, 2012; Halldén, 2003). Avhandlingen har därmed det enskilda barnet som utgångspunkt i analysen av hur socialtjänsten uppmärksammar barns egna upplevelser samt hur de tar hänsyn till individuella barns förutsättningar i utredningar om deras behov av stöd och skydd

\subsubsection{Barn som subjekt och sociala aktörer}

En annan central utgångspunkt är teorier om hur barn och barndom kan förstås. Sedan 1980talet har det skett en övergripande förändring i synen på barn och barndom genom den teoriinriktning som kommit att benämnas barndomssociologi. Inom denna riktning finns ett gemensamt ställningstagande att barn ska ses som subjekt och som sociala aktörer med egna kompetenser istället för som passiva objekt i vuxnas fostran och omsorg. Utifrån detta teoretiska perspektiv förstås barn som individer med egna behov och intressen (James \& Prout, 1997; Qvortrup, 1997; Qvortrup, Bardy, Sgritta \& Wintersberger, 1994) men också som aktiva, kreativa, interagerande, meningsskapande och förhandlande med sin omgivning (Meadows 2010; James \& Prout, 1997; James, Jenks \& Prout, 1998). Det betyder att barn inte bara påverkas av sin omgivning utan att de också är en del av den socialisationsprocess där de själva ingår (Halldén, 2003; Meadows, 2010). Barn, deras åsikter och upplevelser kan därmed tolkas som lika värdefulla som vuxnas (Prout, 2005).

I den här avhandlingen har två inriktningar inom barndomssociologin haft betydelse. Det ena är det strukturalistiska perspektivet där barn förklaras tillhöra en speciell kategori av människor i samhället. Det innebär att barn som grupp, i ett visst samhälle under en given 
period, har vissa gemensamma förutsättningar i sin livssituation som kan jämföras med andra gruppers förutsättningar. Utifrån en sådan syn på barn och barndom kan det individuella barnets möjligheter att agera inte frikopplas från sociala och samhälleliga strukturer (Alanen, 2001; Qvortrup, 1990, 1994).

Det andra perspektivet av betydelse utgår i från att barn måste förstås utifrån sina unika förutsättningar. Det betyder barn upplever, interagerar med andra samt hanterar sin omgivning på individuella sätt. De har också individuella förutsättningar att utvecklas olika beroende på bland annat kön, ålder, etnicitet, ekonomi och livsomständigheter. Barn har därmed olika status, behov och möjligheter vilket leder till att de agerar och bidrar till sin livssituation utifrån sina unika förutsättningar. Det kan också göra att de agerar på olika sätt både inom och emellan olika sociala arenor vid olika tillfällen (James m. fl., 1998). Barn förstås därmed ha individuella egenskaper, kompetenser, upplevelser, erfarenheter och tillvägagångssätt som de hanterar sin omgivning utifrån även om de inte är autonoma och oberoende av sin omgivning. Dessutom anses strukturer i samhället också skapas i interaktion mellan individer snarare än att existerande strukturer uteslutande formar människors agerande (Prout, 2005). Det betyder att analyserna i avhandlingen utgår från att såväl samhälleliga strukturer som barns individuella förutsättningar kan påverka barns aktörskap.

\subsubsection{Socialkonstruktionism och diskursanalytisk ansats}

Min tolkning och analys av det skrivna språket i socialtjänstens barnavårdsutredningar har inspirerats av socialkonstruktionism och diskursanalys. Diskursanalys är bara ett av flera socialkonstruktionistiska angreppssätt och det finns dessutom ett antal diskursanalytiska inriktningar. Här ges en överblick över vilka diskursanalytiska ställningstaganden som varit utgångspunkt i den här avhandlingen.

Socialkonstruktionismen innebär ett förhållningssätt som inte betraktar det direkta och omedelbara som självklart eller givet utan istället utgår ifrån att sociala fakta skapas genom social interaktion. Det är individer som tillsammans utformar förståelse för omvärlden (Barlebo Wennberg, 2000; Burr, 2003; Collin, 1997).

Utgångspunkten är att språket och vårt sätt att använda språket inte är neutralt. Språket speglar alltså inte en existerande verklighet. Istället tolkar och skapar vi vår sociala verklighet genom språket då beskrivningar, representationer och förklaringar reflekterar hur något är och ska tolkas. Därigenom bidrar språket till att framställa vad som ska förstås som en objektiv verklighet. Kontextuella faktorer så som exempelvis var, när och vilka individer som deltar samt $\mathrm{i}$ vilket sammanhang har betydelse för vilka beskrivningar som blir giltiga och möjliga men också vilka som inte blir det. Beskrivningar är därmed aldrig självklara utan måste ses i relation till den praktik där de uppstår. Vår kunskap om världen är på så sätt beroende av interaktionen med andra människor och vår omgivning och kan förändras över tid. För den här avhandlingen betyder det att föreställningar om barn och barns hälsa skapas och upprätthålls genom social interaktion. Konsekvensen blir att den sociala världen inte är förutbestämd av yttre förhållanden. Man kan därmed inte tala om människors egenskaper eller om andra sociala företeelser som om de var självklara eller okomplicerade. Även om utgångspunkten är att utredningarna analyseras som socialt konstruerade så förnekas inte existensen av barns fysiska och psykiska hälsa. Språket blir dock ett riktmärke för hur vi 
förstår tillvaron och hur vi vill att andra ska se på den i ett visst sammanhang (Burr, 2003; Potter, 1996; Potter \& Wetherell, 1995: Wetherell, Taylor \& Yates, 2001). Texter är dessutom handlingsorienterade då språk används som en resurs för att framställa sig själv eller omgivningen på ett visst sätt. En beskrivning kan därmed fylla en funktion i den kontext där den skapats. Beroende av den förståelse som skapas blir vissa handlingar möjliga och andra inte, det vill säga det finns ett samband mellan hur något beskrivs och hur människor sedan agerar (Burr, 2003; Potter \& Wetherell, 1987, 1995; Wetherell, 2001).

Texter, i det här fallet barnavårdsutredningar, förstås därmed som komplexa, kulturella och psykologiska produkter som skapats utifrån det sociala arbetets förutsättningar (Potter \& Wetherell, 1987). Det innebär att beskrivningar av barns fysiska och psykiska hälsa eller upplevelser kan påverkats av socialsekreterarnas interaktion med andra människor men också av lagar och konventioner samt hur socialtjänsten bestämt att arbetet med utredningen ska organiseras. Dessutom kan föreställningar om barn och deras kapacitet ha betydelse för hur formuleringar utformas.

\subsubsection{Betydelsen av beskrivningars innehåll och form}

I och med att socialtjänsten ska bedöma barns behov av stöd och skydd gör socialsekreterare också klassificeringar av individer och deras problem vilket sker genom att de framställer dem på vissa sätt (Börjesson \& Palmblad, 2008; Hall m. fl., 2006). Det betyder att en individ som sägs tillhöra en viss kategori inte absolut har vissa personlighetsdrag, behov eller problem. Kategorisering kan istället ses som en interaktiv och retorisk process där förståelsen för exempelvis en person eller händelse skapas under utredningsprocessen. Det här kan exempelvis ske genom beskrivningar, formuleringar och struktur i en text. Socialsekreterares förklaringar, motiveringar och tillskrivandet av ansvar för vad som orsakat en viss situation ger innehållet i de olika kategorierna. Etableringen av en kategoritillhörighet kan dessutom göras genom att argumentationen framställer en viss beskrivning som mer trolig än någon annan (Burr, 2003; Börjesson, 2004, 2008; Hall m. fl., 2006; Wetherell , 2001). En beskrivning kan dessutom innebära att de aspekter som lyfts fram därmed blir mer relevanta än andra som inte tas upp (Hall m. fl., 2006; Potter 1996; Potter \& Wetherell, 1995).

Dessutom kan förståelsen i en text påverkas av de ord som används (Potter, 1996). Med vilken säkerhet något beskrivs kan också få konsekvenser för hur det uppfattas. En formulering som presenteras som fakta kan uppfattas som trovärdig medan det som beskrivs med mindre säkerhet kan framstå som mindre tillförlitligt. Generella beskrivningar av ett fenomen är också ett sätt att förstärka trovärdigheten i en beskrivning då dessa kan framstå som allmängiltiga och objektiva (se exempelvis Börjesson, 2003; Potter, 1996).

Detaljrikedomen i en beskrivning är ytterligare en faktor som kan påverka förståelsen för ett barns livssituation. Detaljrika beskrivningar kan uppfattas som trovärdiga då de skapar en tydlig bild av hur någon upplevt en annan person eller situation samt hur slutsatser dragits. Konsekvensen av vaga beskrivningar kan å andra sidan medföra att innebörden uppfattas som otydlig samtidigt som innehållet kan bli svårt att ifrågasätta just på grund av den begränsade information som ges. En beskrivning kan även få olika betydelse beroende på hur personen som tillskrivs uttalandet framställs. En persons trovärdighet kan också definieras genom redogörelser för personliga egenskaper men även genom att yrkestitel eller 
institutionstillhörighet (Potter, 1996). Vid beskrivningar av barns hälsa i socialtjänstens utredningar kan exempelvis läkares och psykologers uttalande ges hög status.

Hur ett enskilt barn blir förstått kan därmed bero på hur innehållet i beskrivningen har formulerats. Utifrån den diskursanalytiska ansatsen kan beskrivningar av barns fysiska och psykiska hälsa samt barns upplevelser förstås som en del i kategoriseringen av barn. På så sätt kan hälsobeskrivningar få faktiska och praktiska konsekvenser då en kategorisering kan påverka förståelsen för barns behov och därmed vilka beslut om stöd och insatser som blir möjliga (Hall m. fl., 2006).

\subsection{Empiriskt material}

Dokumentationen under en barnavårdsutredning ska klargöra vilken information som använts för att fatta beslut i ett ärende. För att få fördjupad förståelse för hur socialsekreterare uppmärksammar barns fysiska och psykiska hälsa samt barns egna upplevelser när de ska bedöma barns behov av stöd och skydd genomfördes en aktstudie.

Avhandlingsprojektet bygger på material från 272 utredningar genomförda enligt socialtjänstlagen (11:1 och 2) gällande 259 barn i socialtjänstens individ- och familjeomsorg i en mellanstor kommun i Sverige. I likhet med FN:s konvention om barnets rättigheter och socialtjänstlagen används benämningen barn för alla individer i åldern 0 upp till 18 år.

Materialet består av dokument som författats eller samlats in av socialsekreterare under utredningstiden så som utredningsdokument, journalanteckningar, rapporter och vårdplaner. Utredningsdokumenten är de dokument där socialsekreterare sammanfattar den information som inhämtats samt underbygger de beslut som fattas i utredningen. I utredningarna som studerats till denna avhandling varierar utredningsdokumentet $\mathrm{i}$ omfång från 1 till ca 25 sidor. I journalanteckningarna beskrivs händelser där barnet deltagit men också aktiviteter där andra personer så som föräldrar, syskon, släkt och professionellt nätverk medverkat. I dessa anteckningar redogörs för hembesök samt möten på socialkontoret, förskola/skola eller andra vård- och stöd verksamheter, vem som varit närvarande vid mötet samt vilka beslut som fattats. Det finns även noteringar om telefonsamtal som socialsekreterare haft med olika personer. Journalanteckningarnas omfattning varierar från ett par sidor till uppskattningsvis cirka 50 sidor i de olika ärendena. Barnens akter innehöll också dokument som skickats via brev eller lämnats personligen till socialkontoret och som berörde aktuellt barn och ärende. Dessa dokument innehöll rapporter och bedömningar från andra professionella så som förskollärare, lärare, läkare, polis eller personal på olika vård- och behandlingsinstitutioner. I rapporterna beskrivs exempelvis barns vistelse på förskola/skola och hur deltagande i verksamheten samt relationer till andra människor fungerar. Det finns också beskrivningar av barns besök i sjukvården och resultat av undersökningar och utredningar. Redogörelser från polisen innehöll information om förhör eller annan kontakt med barnet eller föräldrarna. Rapporter från olika vård- och stödverksamheter innehöll information om den verksamhet som barn och/ eller föräldrar deltagit i. Det finns också vårdplaner där socialsekreterare utifrån den bedömning de gjort formulerar mål med fortsatt vård utifrån barnets behov. Då barnen som utreds har haft olika många tidigare kontakter med olika instanser i samhället och då socialtjänstens utredningar varierade i tillvägagångssätt skiljer sig omfånget på dokumentationen åt i de olika ärendena. Därmed varierar omfånget på 
den totala dokumentationen mellan ett par sidor upp till ca 100 sidor text för olika utredningar.

\subsubsection{Avgränsning av det empiriska materialet}

Data i avhandlingen bygger på dokumentation från utredningar som genomförts enligt socialtjänstlagen (11:1 och 2) under 2008 efter att en anmälan inkommit till socialkontoret. Utredningar som genomförts på grund av familjers egen ansökan om stöd från socialkontoret har däremot exkluderats. Anledningen till att välja utredningar som genomförts efter anmälan var en vilja att uppmärksamma utsatta barn i den bemärkelsen att det fanns någon utanför barnets boendefamilj som uttryckt en oro för barnets livssituation. I tre av studierna gjordes valet att fokusera på utredningar där socialtjänsten uppgav att det fanns en oro för barnets hälsa, totalt 60 utredningar (studie 2 och 3) respektive 35 utredningar (studie 4). Detta urval gjordes med syftet att studera hur hälsoaspekter uppmärksammas när barnens hälsa initialt har beskrivits som ett problem. Detta är dock socialsekreterares formuleringar för att motivera en utredning vilket innebär att det inte är möjligt att veta hur andra skulle bedöma barnens hälsostatus. Det som analyserats är skriftliga dokument. Därmed uppmärksammas inte vad som i övrigt skett under utredningens gång inklusive hur socialsekreterare och andra personer muntligen resonerat utöver det som dokumenterats.

\subsection{Etiska överväganden}

Socialtjänstens utredningar samt övriga handlingar från barnens akter har lästs och kodats på socialkontoret och därefter förvarats i de tillgängliga arkiv som finns där. Registrering och bearbetning av personuppgifter har skett manuellt och aldrig bearbetats via dator. Alla personuppgifter har också sparats på socialkontoret. Den data som tagits från socialkontoret har avidentifierats före kodning. Kodat material har förvarats i stöldsäkert skåp på Institutionen för beteendevetenskap och lärande, Linköpings universitet, där analysarbetet utförs. I de kvalitativa studierna, studie 2, 3 och 4 har de citat som används avpersonifierats genom att namn på personer och platser tagits bort. Studien har ett etiskt godkännande från den Regionala etiska kommittén i Linköping, Sverige (Dnr 221-08).

\subsection{Datainsamling}

Vid datainsamlingen togs först en kontakt med socialchefen som gav tillåtelse till att efter ett etiskt godkännande genomföra studien på socialkontoret. Därefter inhämtades en lista, från ansvariga på kommunen, med de utredningar som inletts under 2008 som var det kalenderår som skulle studeras. När detta var gjort identifierades de aktuella ärendena och all dokumentation från att utredningen inleds till att ett beslut fattas, samlades in.

I nästa steg studerades och kodades hela utredningsmaterialet från tre av kommunens socialkontor. Efter en grundlig genomgång av materialet bedömdes detta vara ett tillräckligt antal utredningar att analysera och därför inkluderades aldrig det fjärde socialkontoret. I den första delstudien (studie 1) inkluderades och kodades alla dokument som tillhörde de aktuella barnavårdsutredningarna för att få en uppfattning om den information som socialsekreterare samlat in och nedtecknat om barnets fysiska och psykiska hälsa. Därutöver kodades 
information om barnen och deras livssituation så som kön, ålder, boendesituation och föräldrars sysselsättning. Även information om utredningarnas övergripande struktur så som typ av utredning, anmälare, anledning till utredning samt förslag till beslut. I delstudie två och tre inkluderades endast den del av utredningsdokumentet där socialsekreterare analyserat och argumenterat för den bedömning de gjort och de beslut de fattat. I utredningsdokumentet benämns de avsnitten oftast analys, bedömning och beslut. I den fjärde delstudien ingår utredningsdokumentet $\mathrm{i}$ utredningar genomförda enligt handläggning- och dokumentationssystemet BBIC. Här är fokus specifikt på den information som fanns om barnen i de sju behovsområden som uppmärksammas i BBIC.

\subsubsection{Beskrivning av barnen}

Totalt handlar utredningarna i denna avhandling om 259 barn. Att antalet utredningar $(n=272)$ är fler än antalet barn beror på att 13 barn utreddes två gånger. Barnen är mellan 017 år då utredningarna inleds. Det innebär att de äldsta barnen vid utredningens inledning inte hunnit fylla 18 år men gör det under samma år. De yngsta barnen föds det år som utredningen inleds och fyller följaktligen inte 1 år förrän året efter. Det är ungefär lika många flickor som pojkar som utreds (Tabell 1).

Tabell 1 Barnens ålder

$M=10.3(S D=5,1)$, intervall $0-18(n=259)$

\begin{tabular}{lccl} 
& & & $\mathrm{n}(\%)$ \\
\hline & Flickor & Pojkar & Totalt \\
$0-5$ år & 27 & 26 & $53(20,4)$ \\
$6-10$ år & 33 & 39 & $72(27,8)$ \\
$11-14$ år & 29 & 31 & $60(23,2)$ \\
$15-18$ år & 44 & 30 & $74(28,6)$ \\
\hline Totalt & $133(51,4)$ & $126(48,6)$ & 259
\end{tabular}

De flesta av barnen lever tillsammans med åtminstone en av sina biologiska föräldrar. $6 \%$ av barnen är placerade av socialtjänsten (Tabell 2).

Tabell 2 Barnens Boendesituation*

\begin{tabular}{ll}
\hline Båda biologiska föräldrarna & $62(23,9)$ \\
En biologisk förälder & $128(49,4)$ \\
Delat boende mellan båda biologiska föräldrar & $34(13,1)$ \\
Placerad av socialtjänsten & $16(6,2)$ \\
\hline
\end{tabular}


Många av barnen (ca 77 \%) som utretts har syskon, de flesta har helsyskon men en del har också syskon som de endast har en gemensam förälder med (Tabell 3).

\begin{tabular}{ll} 
Tabell 3 Barnens Syskon* & $\mathrm{n}(\%)$ \\
\hline Helsyskon & $123(47,5)$ \\
Halvsyskon & $23(8,9)$ \\
Både hel-och halvsyskon & $54(20,8)$ \\
\hline
\end{tabular}

Cirka hälften av barnens föräldrar uppges arbeta, studera eller vara föräldralediga. Det är fler mammor än pappor som uppges vara arbetslösa (Tabell 4).

Tabell 4 Föräldrars sysselsättning* n (\%)

\begin{tabular}{lll} 
& Mamma & Pappa \\
\hline Arbete, studier eller föräldraledighet & $118(45,6)$ & $120(46,3)$ \\
Arbetslöshet & $50(19,3)$ & $19(7,3)$ \\
Sjukskrivning eller sjukpensionär & $23(8,9)$ & $10(3,9)$ \\
\hline
\end{tabular}

*I ovanståenden tabeller (tabell 2-4) saknas information i 19 till 110 utredningar beroende på variabel som anges.

\subsubsection{Beskrivning av barnavårdsutredningarna}

När datainsamlingen av de 272 barnavårdsutredningar genomfördes var socialkontorens policy att barnavårdsutredningar skulle genomföras utifrån handläggning- och dokumentationssystemet BBIC men implementeringen av arbetssättet hade precis påbörjats. Det innebär att endast $62 \%$ av de utredningar som ingår i hela projektet är genomförda enligt BBIC. Övriga utredningar följer inte någon särskilt utformad utredningsmall (Tabell 5).

\begin{tabular}{ll} 
Tabell 5 Typ av utredning & $\mathrm{n}(\%)$ \\
\hline BBIC $^{*}$ & $169(62,1)$ \\
Annan typ av utredning & $103(37,9)$ \\
\hline
\end{tabular}

\footnotetext{
*Enligt Socialstyrelsens krav måste en utredning enligt handläggning- och dokumentationssystemet BBIC vara skriven i en BBIC- mall (www.socialstyrelsen.se). Då det i det insamlade materialet fanns utredningar som inte var skrivna i den datoriserade mallen men ändå följde samma mönster och rubrikssystem som BBIC har jag valt att även räkna dessa utredningar som BBIC-utredningar.
}

Anmälningarna som föranledde de barnavårdsutredningar som studeras kommer i första hand från skolan eller någon av socialtjänstens verksamheter så som öppenvårdsverksamheter och institutionella verksamheter för barn eller vuxna (Tabell 6). 
Tabell 6 Anmälare $(n=269) * *$

\begin{tabular}{|c|c|}
\hline Skola/förskola & $83(30,5)$ \\
\hline Socialtjänst & $61(22,4)$ \\
\hline Polis & $29(10,7)$ \\
\hline Sjukvård & $31(11,4)$ \\
\hline Förälder*** eller annan närstående & $19(7,0)$ \\
\hline Övriga $* * * *$ & $46(16,9)$ \\
\hline
\end{tabular}

De vanligast förekommande orsakerna till att utredning inleds anges vara oro för föräldrars levnadssituation och beteende så som missbruk, kriminalitet, ohälsa, konflikter eller försummelse av barn. I ca $26 \%$ av utredningarna angavs både föräldrar och barn vara anledning till utredningen. Minst förekommande var utredningar där orsaker till att inleda utredningen angavs vara oro för barnens hälsa, skolproblem, missbruk eller beteende (Tabell 7).

\begin{tabular}{ll} 
Tabell 7 Anledning till utredning & $\mathrm{n}(\%)$ \\
\hline Föräldrar & $139(51,1)$ \\
Barn & $61(22,4)$ \\
Både föräldrar och barn & $72(26,5)$ \\
\hline
\end{tabular}

Det är fler utredningar som leder till beslut om fortsatt stöd än utredningar som avslutas utan vidare åtgärd. Det vanligast förekommande förslaget om åtgärd var öppenvård enligt socialtjänstlagen (SoL) medan placeringar enligt lagen med särskilda bestämmelser om vård av unga (LVU) föreslås i minst utsträckning (Tabell 8).

\begin{tabular}{ll} 
Tabell 8 Förslag till beslut* & n $(\%)$ \\
\hline Utan vidare åtgärd & $120(44,1)$ \\
Öppenvård enligt SoL & $91(33,5)$ \\
Placering enligt SoL & $41(15,1)$ \\
Placering enligt LVU & $19(7,0)$ \\
\hline
\end{tabular}

*Information om vilken typ av beslut som fattas saknas i en utredning

I ca $66 \%$ av det totala antalet utredningar finns information om att socialsekretaren samtalat med barnet under utredningstiden, antingen tillsammans med någon (ca $10 \%$ ) eller i enskilda samtal (ca $56 \%$ ) (Tabell 9). 
Tabell 9 Barns deltagande i utredningen*

\begin{tabular}{ll}
\hline Samtal tillsammans med någon & $28(10,3)$ \\
Enskilda samtal (inkl telefonsamtal) & $152(55,9)$ \\
Inga samtal & $55(20,2)$ \\
\hline
\end{tabular}

*I 37 av utredningarna finns ingen uppgift om barns deltagande

\subsubsection{Skriftliga och muntliga uttalanden från medicinsk expertis} I 40 (15\%) av de 272 barnavårdsutredningarna finns skriftliga uttalanden från medicinsk expertis som bilagor. Totalt handlar det om 50 olika uttalanden vilket innebär att det finns mer än ett utlåtande från medicinsk expertis i några av utredningarna.

Det är stor variation på typ av yttrande då det både handlar om anmälningar (14), psykolog/ neuropsykologiska utredningar (5), journaler och sammanfattningar från BVC (9), journaler och övriga sammanfattningar av läkarkontakter angående fysisk hälsa (14) samt journaler och övriga sammanfattningar av läkarkontakter gällande psykisk hälsa (8).

Totalt 7 av dessa 50 utlåtanden kommer från medicinska undersökningar eller utredningar som gjorts efter förfrågan från ansvarig socialsekreterare (2 psykologbedömningar samt 5 läkarundersökningar som görs för att bedöma om det finns tecken på fysisk misshandel). Det stöddokument som tillhör utredningar som genomförs enligt BBIC och som kan användas för att dokumentera läkarkontakter under utredningen återfanns dock inte i någon av de studerade barnavårdsutredningarna.

I 52 ärenden finns hänvisningar till socialsekreterares muntliga kontakt med någon form av medicinsk expertis, totalt 55 kontakter. Femton av dessa muntliga kontakter finns i samma utredningar där det också finns skriftliga utlåtanden. De muntliga kontakterna socialsekreterare genomfört är samtal med personal på barnavårdscentraler (16), läkare (10) och psykologer, kuratorer eller terapeuter (29) på andra vårdinstanser.

\subsection{Metod}

I den här avhandlingen har både kvantitativ och kvalitativ metod används för att belysa de aktuella forskningsfrågorna. Kvantitativa beräkningar användes i den första delstudien medan delstudie två, tre och fyra hade en kvalitativ ansats.

\subsubsection{Kvantitativ metod}

\subsubsection{Studie 1}

Syftet med studien var att undersöka vilka hälsoaspekter som socialsekreterare uppmärksammar i dokumentationen när de utreder barns livssituation. För att kunna kartlägga beskrivningar av barns fysiska och psykiska hälsa skapades en kodmanual med underliggande tema för respektive hälsokategori. Därefter genomfördes en provkodning av fem barnavårdsutredningar för att förstå om kodmanualens teman var relevanta för kartläggningen eller om den behövde utvecklas ytterligare. Urvalet av de fem utredningarna, hade en spridning på barnens ålder och kön. Genomgången av socialsekreterarnas beskrivningar klargjorde vilka teman som kunde vara aktuella under respektive kategori. När det i kodningen uppenbarade sig nya temataiska områden justerades kodmanualen och tidigare genomförda utredningar omkodades för att alla utredningar som ingår i studien skulle 
kodas utifrån samma kodmanual. Därefter påbörjades kodningen av de övriga akterna. Kodningen av de tio första utredningarna granskades av författare tre och fyra. De få avvikande tolkningar som framkom diskuterades och överenskommelser gjordes kring hur de skulle kodas. Efter sådana beslut kontrollerades de tidigare kodade utredningarna för att samtliga skulle få samma kodning. Uppstod tveksamheter under resterande delen av kodningen diskuterades dessa med författare tre och fyra.

Det som fördes in i kodmanualen var socialsekreterares formuleringar av barns hälsa. De beskrivningar som hittades fördes in under passande kategori och tema. I varje ärende nedtecknades också bakgrundsvariabler som ålder, kön, familj (föräldrar och syskon), föräldrars sysselsättning och hälsa samt socialt stöd (vänner, släkt och andra vuxna). Likaså inkluderades information om anledningen till utredningen; det vill säga om socialsekreteraren angav att det var barnet (t.ex. skolproblem, hälsoproblem) eller föräldrarna (t.ex. beteende, hälsoproblem eller individuella karaktäristik) som var orsak till att utredningen genomfördes.

Inför databearbetningen strukturerades fynden från kodningen i följande grupper; generella hälsobeskrivningar (beskrivningar där socialsekreterare använder begreppen hälsa eller mående); generell fysisk hälsa (beskrivningar där socialsekreterare använder begreppet fysisk hälsa eller fysiskt mående) samt generell psykisk hälsa (beskrivningar där socialsekreterare använder begreppet psykisk hälsa eller psykiskt mående). Socialsekreterares beskrivningar av fysisk hälsa som tillfredställande eller problematisk i mer specifika termer delades in i grupperna: neurologiska sjukdomar (motorik, syn, hörsel, övriga centrala nervsystemet, epilepsi ); tillväxt och utveckling (längd, vikt); inflammatoriska och autoimmuna sjukdomar (astma och andra allergier, infektioner, immunförsvar, lungor/andning, hud, diabetes, reumatism); mag-tarm- och njursjukdomar (njurar, lever, buk, tänder, blod); psykosomatiska symtom (huvudvärk, magvärk och sömnproblem); droganvändning (bruk av alkohol och andra droger). Socialsekreterares beskrivningar av psykisk hälsa i mer specifika termer delades in i grupperna; problematiska känslor och beteenden (stress, oro, nedstämdhet, tvångstankar och aggressivitet); positiva känslor och beteenden (glädje, lugn, trygghet, välanpassat beteende); självmordstankar, självmordsbeteenden; kognitiva förmågor (tal, kommunikation, dyslexi) och neuropsykologiska problem (neuropsykologiska svårigheter och diagnoser).

Socialsekreterarnas mer specifika beskrivningar av känslor skiljde sig från övriga beskrivningarna av hälsa. Vid känslobeskrivningar användes olika ord medan övriga hälsoaspekter beskrevs som existerande eller inte utifrån en specifik term. Beskrivningarna av barnens upplevda känslor delades därför in i två separata kategorier medan de andra grupperna inkluderar både närvaro och frånvaro av ett visst hälsotillstånd. Den slutgiltiga indelningen av socialsekreterarnas hälsobeskrivningar innehöll därmed 15 olika grupper.

Därefter genomfördes en klusteranalys. Syftet med en klusteranalys är att systematisera data till ett överblickbart mönster. Denna typ av analys kan användas då det finns få teoretiska antaganden kring utfallet (Xu \& Wunch, 2009). I denna studie var det specifika syftet att gruppera utredningarna i olika subgrupper (kluster) för att hitta likheter och skillnader i valda variabler (Bergman \& Magnusson, 1997). På så sätt kunde variationer mellan utredningarna vad gäller beskrivningar av barns fysiska och psykiska hälsa identifieras. För att identifiera den statistiskt mest giltiga uppdelningen i subgrupper utfördes flera klusteranalyser av typen $k$-means. Analyser på två upp till fem kluster genomfördes. 
Därefter genomfördes chi-två-test för att validera klustren i termer av signifikanta skillnader mellan de variabler (beskrivningar av barns fysiska och psykiska hälsa) som inkluderats i analysen. Analysen med fyra kluster visade på signifikanta skillnader mellan kluster för alla valda variabler och valdes därför ut för vidare analys. Slutligen jämfördes de fyra klustren med avseende på information om utredningarna och barnen genom en-vägs variansanalyser (ANOVA) och chi-två-test, beroende på skalnivån på de oberoende variablerna. Variablerna som inkluderades var exempelvis barnets ålder, kön, boendesituation, typ av utredning, anledning till utredning och beslut.

\subsubsection{Kvalitativ metod}

De kvalitativa studierna är inspirerade av socialkonstruktionism och diskursanalytiska antaganden. De texter som ingår i de kvalitativa studiernas är utdrag från olika delar av 60 skriftliga utredningsdokument. Analysen i de kvalitativa studierna hanterar därmed inte journalanteckningar, rapporter eller vårdplaner i barnavårdsutredningarna. De 60 utredningar som valdes ut var de utredningar där socialsekreterare initialt uttryckte en oro för barnets fysiska och/eller psykiska hälsa.

\subsubsection{Studie 2}

Analysen i studie 2 genomfördes för att förstå hur socialsekreterare argumenterar för barns fysiska och psykiska hälsa i bedömningar av barns behov av stöd och skydd. Analysen var inspirerad av socialkonstruktionism och diskursanalys och det fanns ett fokus på det språk som används i utredningarna. Utgångspunkten är att språk och vårt sätt att använda språket inte är neutralt. Istället tolkar och skapar vi vår sociala verklighet genom språket då beskrivningar och förklaringar uttrycker hur något eller någon bör uppfattas. Beroende på den förståelse som skapas så blir vissa handlingar möjliga och andra inte (Burr 2003; Potter 1996; Potter \& Wetherell, 1995). Hur socialsekreterare konstruerar förståelse för barns fysiska och psykiska hälsa kan därmed påverka bedömningar och beslut om barns behov av stöd. I de 60 utredningar som studerades framgick en oro för barnens fysiska och/eller psykiska hälsa i socialsekreterarnas motivering till att utredningen inleddes.

Först kodades de orsaker som socialsekreterarna angivit som anledning till att en utredning inletts. Därefter identifierades de delar där socialsekreterarna i sina argument för beslut refererade till barnens fysiska och/eller psykiska hälsa. Dessa delar lästes om och om igen för att finna likheter och skillnader i beskrivningarnas innehåll och struktur. De två första författarna diskuterade sedan fynden och organiserade därefter dessa i olika teman som kunde svara på studiens frågeställningar. Alla tre författare diskuterades sedan de framtagna temana. Under denna process valdes några teman bort och andra tillkom. När alla författare slutligen var överens om validiteten i de valda temana avslutades den analytiska processen.

\subsubsection{Studie 3}

I studie 3 var syftet att förstå hur barns egna röster om sin fysiska och/eller psykiska hälsa synliggörs då socialsekreterare argumenterar för de beslut de fattar. Data för analys baserades på samma utredningar som i studie 2, det vill säga de 60 utredningar där åtminstone en specifik orsak för att inleda utredning var oro för barns fysiska och/eller psykiska hälsa. 
Inspirerad av socialkonstruktionism och diskursanalys var fokus är på det språk som används. Utgångspunkten i studiens analys är på textens retoriska organisation och på språkligt innehåll då dessa delar kan vara av betydelse för den förståelse som skapas i texten (Potter, 1996; Silverman, 2006). Det kan exempelvis handla om ordval, en beskrivnings detaljrikedom, med vilken säkerhet något framförs och hur personen som tillskrivs ett uttalande framställs (Potter, 1996).

Först identifierades de meningar där socialsekreterarna redogjorde för barnens fysiska och/eller psykiska hälsa när de argumenterar för de beslut de fattar. Efter det identifierades de beskrivningar där socialsekreterare specifikt refererade till barns röster om sin hälsa. Dessa beskrivningar jämfördes också med socialsekreterares beskrivningar av vad andra personer har uppgett om barnens hälsa. När denna sammanställning var klar lästes den igenom vid upprepade tillfällen för att finna likheter och skillnader i innehåll och form. De två författarna organiserades sedan fynden i teman. Efter detta läste de två författarna återigen beskrivningarna och då i förhållande till de valda temana. Under denna fas var det några teman som valdes bort och andra som tillkom. Den analytiska processen avslutades när författarna slutligen var överens om validiteten i de teman som valts.

\subsubsection{Studie 4}

Studie 4 syftar till att belysa hur barns identiteter konstrueras i utredningar som genomförts enligt handläggning- och dokumentationssystemet BBIC och då utifrån de beskrivningar som redogjorde för barns upplevelser av sig själva och sin situation. I utredningsmallen för BBIC finns specifika kolumner där barns erfarenheter ska redovisas för var och en av de sju inkluderade behovsområdena. Först sorterades BBIC-utredningarna ut från de 60 utredningar där oro för barnets fysiska eller psykiska hälsa angavs som orsak till att utredningen genomfördes. Totalt 35 utredningar var genomförda enligt BBIC.

Även i denna studie användes en kvalitativ ansats som inspirerats av socialkonstruktionism och diskursanalys. Ett socialkonstruktionistiskt perspektiv som innebär att identiteter konstrueras i social interaktion men också i diskurser. Utgångspunkten är att diskurser är handlingsorienterade (Potter, 2003) och därför ska förstås utifrån den kontext där de verkar (Potter \& Wetherell, 1995; Taylor, 2001; Wetherell \& Potter, 1992). Det betyder att beskrivningar av identiteter kan konstrueras för att uppnå vissa sociala handlingar (Benwell \& Stokoe, 2006). Utredningarna analyserades därmed som en diskursiv praktik där identitetsbeskrivningar formuleras genom berättelser om barn och deras livssituation (Holstein \& Miller, 1993; Hydén, 1991). Beskrivningar av barnens upplevelser sågs därmed som en del i dessa identitetsnarrationer.

Till att börja med identifierades de avsnitt där socialsekreterarna redogjorde för barnens upplevelser och uppfattning i de sju behovsområden som inkluderas i mallen för utredningar enligt BBIC. När dessa avsnitt var sammanställda lästes dessa om och om igen. Analysen fokuserade på det språk som användes för att finna likheter och skillnader i beskrivningarna. De fynd som uppmärksammats diskuterades därefter mellan de två författarna som också tillsammans organiserade empirin i teman. I den fjärde fasen av processen läste båda författarna återigen socialsekreterarnas beskrivningar i relation till de teman som valts. Under detta arbete valdes några teman bort medan andra tillkom. Den 
analytiska processen avslutades när författarna slutligen var överens om validiteten i de teman som valts.

\subsection{Sammanfattning av studiernas resultat}

\subsubsection{Studie 1}

\section{Vulnerable children's health- as described in investigations of reported children}

Nationella och internationella studier visar att barn som placerats av socialtjänsten ofta har ett flertal hälsoproblem (McAuley \& Davis, 2009; Socialstyrelsen 2013b; Vinnerljung m. fl., 2006). Kunskap om hur socialtjänsten uppmärksammar barns fysiska och psykiska hälsa i barnavårdsutredningar är dock begränsad. Den här studien syftade därför till att öka kunskapen om vilka hälsoaspekter som lyfts fram och dokumenteras i utredningar om deras utsatthet. Data för analysen är 272 barnavårdsutredningar som inkluderar 259 barn. Metod för analys var klusteranalys. Analysen med fyra kluster visade på signifikanta skillnader mellan kluster för alla valda variabler och valdes därför ut för vidare analys. Klustren benämndes a) Begränsad information om hälsoaspekter, b) Neurologiska sjukdomar och psykosomatiska symtom, c) Emotionella hälsoaspekter och d) Fysisk och psykisk hälsa och Destruktivt beteende. Slutligen jämfördes de fyra klustren med avseende på information om utredningarna och barnen genom en-vägs variansanalyser (ANOVA) och chi-två-test, beroende på skalnivån på de oberoende variablerna. Variablerna som inkluderades var barnets ålder, kön, boendesituation, typ av utredning, anledning till utredning och beslut.

Resultatet visar att informationen om barns hälsa var begränsad. Information om stress, oro, sorg och ilska var de hälsoaspekter som var mest förekommande. Beskrivningar om självmordstankar, självskadebeteende och mag-, tarm- och njursjukdomar (t.ex. sjukdomar kopplade till lever, tänder, njurar och blod) var minst förekommande. Den grupp som innehöll minst information om barns hälsa, Begränsad information om hälsoaspekter i klusteranalysen innehöll den största andelen utredningar. De tre andra klustergrupperna, Neurologiska sjukdomar och psykosomatiska symtom, Emotionella hälsoaspekter och Fysisk och psykisk hälsa och Destruktivt beteende, bestod mestadels av utredningar utförda enligt BBIC mallen. Även här var information om barns hälsa begränsad men hälsobeskrivningarna var fler i dessa grupper jämfört med den första gruppen, Begränsad information om hälsoaspekter.

Slutsatsen som görs är att socialtjänsten oavsett utredningsmodell bör utveckla sina beskrivningar av hälsoaspekter hos de barn de utreder. I annat fall finns det en risk att bristande information begränsar möjligheten för välgrundade beslut om barns livssituation och behov av stöd till en gynnsam hälsoutveckling. 


\subsubsection{Studie 2}

\section{Social workers' assessments of children's health when arguing for children's needs}

Enligt socialtjänstlagen och andra riktlinjer har socialtjänsten ansvar för barns hälsa och utveckling. Syftet med studien var att belysa hur socialsekreterare i Sverige argumenterar för barns hälsa när de bedömer barns behov av stöd och skydd. Studien fokuserade specifikt på hur socialsekreterare argumenterar för barns fysiska och psykiska hälsa i bedömningar där det fanns en oro för barnets hälsa när utredningen inleds. Analysen inspirerades av socialkonstruktionism och diskursanalys och totalt ingick 60 barnavårdsutredningar.

Resultatet visar att barns fysiska och psykiska hälsa uppmärksammas i 46 av de 60 utredningarna när socialsekreterare argumenterar för bedömningar av barns behov av stöd och skydd. Det innebär att det var 14 bedömningar där det inte fanns någon hänvisning till barnets fysiska eller psykiska hälsa. Analysen visar även att beskrivningarna överlag var korta och det var störst fokus på orsaker och konsekvenser av barns hälsa som sedan kopplades till de beslut som föreslogs. Det fanns även en skillnad i hur psykisk och fysisk hälsa uppmärksammades. I beskrivningar av psykisk hälsa inkluderades orsaker och tecken på barnens svårigheter. Orsakerna till barnens psykologiska problem förklarades oftast utifrån föräldrars oförmåga och beteende. När tecken på barnens ohälsa skildrades var det deras eget "destruktiva" beteende som uppmärksammades. När det argumenterades för stöd riktat direkt till barnen utgick argumentationen oftast från föräldrarnas oförmåga att möta sina barns behov. I de få utredningar där barnens fysiska hälsa uppmärksammades handlade beskrivningarna generellt mer om föräldrars förmåga att stötta sina barn eller barnens behov av stöd utanför socialtjänstens verksamhet än om själva hälsotillståndet i sig. I vissa utredningar argumenterades i bedömningen för andra hälsoaspekter än de som angavs vara anledningen till att utredningen inleds och då utan att detta kommenterades. Socialsekreterare gjorde därmed sällan en beskrivning av om, och i så fall hur, de på ett mer omfattande sätt analyserat orsaker till barns barn fysiska och psykiska hälsa. Resultatet tyder på att begränsade beskrivningar kan förhindra en djupare förståelse för orsaker till och konsekvenser av enskilda barns hälsobehov. Vår slutsats är att det kan vara nödvändigt att utveckla mer detaljerade riktlinjer som tydliggör hur socialsekreterare kan synliggöra barns fysiska och psykiska hälsa i bedömningar och argumentation för beslut. Det skulle kunna ge en tydligare förståelse för det individuella barnets hälsa och därmed för deras eventuella behov av stöd.

\subsubsection{Studie 3}

\section{Representations of Children's Voices about their health in Social Services arguments in support of their decision}

Då socialtjänstlagen och riktlinjer för barnavårdsutredningars genomförande anger att socialtjänsten ska lyssna på barn så är syftet med den här studien att belysa hur barns upplevelser av sin egen hälsa synliggörs i argumentation för beslut. Specifikt fokus är på ärenden där socialsekreterare initialt uttrycker en oro för barns hälsa. Utifrån en 
diskursanalytisk ansats analyserades 60 barnavårdsutredningar. Barns fysiska och psykiska hälsa eller hälsa i generella termer omnämns i 46 av de 60 utredningarna när socialsekreterare argumenterar för beslut.

Resultatet visar att barns egna upplevelser av sin hälsa nämndes i 12 av dessa argument för beslut. Det betyder att barns röster inte representerades i de flesta av socialsekreterarnas argument. Istället presenterades barns fysiska och psykiska hälsa genom beskrivningar av andra personers uppfattningar. När barns upplevelser av sin hälsa beskrevs gjordes det framförallt med få ord. Barns upplevelser beskrevs exempelvis som en bekräftelse på ett påstående eller någon annans uppfattning. När barns uppfattningar uppmärksammades kunde beskrivningarna också handla om barns förmåga att berätta om sin situation snarare än om detaljer om deras hälsa. Det var endast i två beslutsargumentationer som det fanns detaljerade beskrivningar om barnens upplevelser av sin hälsa. Resultatet tyder på att det behövs ett tydliggörande av hur barn uppfattar sin hälsosituation i argument för beslut. Annars framgår inte vilken hänsyn som tagits till deras uppfattningar i de beslut som fattas.

\subsubsection{Studie 4}

\section{How Social Workers Portray Children's Perceptions When Constructing Their Identities}

Syftet med den här studien var att belysa hur socialsekreterare synliggör barns perspektiv på sig själva och sin livssituation när de konstruerar barns identiteter i BBIC- utredningar. I de 35 utredningar som ingår i studien fanns en oro för barns fysiska eller psykiska hälsa när utredningen inleds. Analysen är inspirerad av diskursanalys då fokus är på språket och hur det används i beskrivningar av barns upplevelser.

Resultaten visar att barns röster presenteras på varierande sätt i 29 av de 35 utredningarna. I de olika områden som är inkluderade i BBICs utredningsmall beskrevs barns upplevelser i: Skola (29 utredningar); Familj och sociala relationer (29 utredningar); Hälsa (22 utredningar); Känslo- och beteendemässig utveckling (22 utredningar); Identitet (17 utredningar); Klara sig själv (9 utredningar) och Socialt uppträdande (4 utredningar). Kvantitativt användes fler ord då barns upplevelser uppmärksammas i jämförelse med föräldrar och andra personers (t.ex. lärare, läkare eller psykologer) beskrivningar av barnen. Den kvalitativa analysen visar dock att socialsekreterares beskrivningar varierade i kvalitet. Det var vanligare att beskrivningarna var förenklade jämfört med att de var specifika. I de förenklade beskrivningarna fanns få detaljer om barns åsikter, känslor och upplevelser. Beskrivningar av barns positiva upplevelser av sin livssituation var också få och mindre utvecklade jämfört med vad som beskrevs som problematiskt. I de specifika beskrivningarna fanns fler detaljer om barns upplevelser, känslor samt åsikter. Störst fokus var även här på problematiska aspekter och barns önskemål inför framtiden var alltför sällan utvecklade. Resultatet tyder på att socialsekreterare gestaltar barns röster i BBIC-utredningar. Däremot behöver formuleringar om barns uppfattningar utvecklas för att kunna öka förståelsen av deras unika behov. 


\section{Sammanfattande diskussion}

Syftet med den här avhandlingen har varit att öka kunskapen om hur barns fysiska och psykiska hälsa samt barns upplevelser synliggörs i barnavårdsutredningar. Detta för att både innehåll och struktur i socialsekreterares formuleringar kan påverka förståelsen för barns hälsa och deras unika behov av stöd. Studierna som ingår i avhandlingen belyser specifikt hur förståelsen för barns hälsa och deras behov av stöd kan påverkas av vilka hälsoaspekter som uppmärksammas i dokumentationen (studie 1), hur socialsekreterare argumenterar för barns hälsosituation (studie 2), hur barns röster om sin egen hälsa synliggörs i socialsekreterares argumentation för beslut (studie 3) samt på vilket sätt barns upplevelser av sig själva och sin livssituation synliggörs i BBIC-utredningar när det finns en oro för deras hälsa (studie 4).

I följande diskussion kommer resultaten att sättas i relation till rättslig reglering, teorier som identifierar barn som subjekt och sociala aktörer samt tidigare forskning.

\subsection{Barns status som subjekt och sociala aktörer- rättslig reglering}

Då beskrivningar aldrig är självklara utan ska förstås i relation till den praktik där de uppstår (Burr, 2003; Potter, 1996; Potter \& Wetherell, 1995; Wetherell m. fl., 2001) så skapas texterna i barnavårdsutredningarna inom ramen för det sociala arbetets förutsättningar. Det betyder att socialsekreterares dokumentation av barns hälsa och barns upplevelser kan påverkas av deras interaktion med andra människor men också av den rättsliga regleringen och hur arbetet är organiserat.

I lagstiftning från början av 1900-talet var samhällets skydd mot individers omoraliska och avvikande beteende i fokus vilket står i kontrast till nuvarande lagstiftning där barns individuella behov av stöd och skydd är det som ska stå i centrum (SoL 5:1). I och med införandet av nuvarande socialtjänstlagen och ratificeringen av Barnkonventionen har också barns rättigheter och synen på dem som självständiga individer förstärkts.

Formuleringar i rättskällorna angående barns fulla människovärde och att hänsyn ska tas till alla individers integritet samt barns bästa talar för detta. Dessutom uttrycks att barn har rätt att få information och ges möjlighet komma till tals i frågor som handlar om dem samt att hänsyn ska tas till deras uppfattningar (SoL; UD, 2006). Med dessa skrivningar tydliggörs att socialtjänsten i sitt utredningsarbete ska ha ett barnperspektiv och att barn ska förstås som subjekt och aktörer. Att barn ska ses som subjekt och inte bara som objekt innebär ett accepterande av att barn har egna behov och intressen samt att de ska ses som självständiga aktörer som är delaktiga i utvecklingen av sin livssituation samt ska ges möjlighet att vara aktiva i frågor som rör dem (Meadows, 2010; James m. fl., 1998; James \& Prout, 1997; Qvortrup, 1990; Qvortrup m. fl., 1994).

I likhet med tidigare lagstiftning finns det dock fortfarande kvar en skillnad i den nuvarande regleringen vad gäller synen på barn och vuxna. I socialtjänstlagen görs exempelvis skillnad på barn och vuxnas aktörskap. Barns begränsade rättsliga handlingsutrymme har övergripande sin grund i regleringen i föräldrabalken även om det finns vissa undantag för barn över 15 år. De har därmed inte någon möjlighet att agera självständigt. Istället betonas deras beroende av vuxna genom att både föräldrar i sin roll som vårdnadshavare och socialtjänst har ansvar för och bestämmanderätt över barns liv (SoL 5:1; 
FB 6 kap.). Så som lagstiftningen är utformad kan barn därmed förstås som subjekt men samtidigt som objekt för andras omsorg och fostran (Mattsson, 2006). Formuleringar om att barn inte ska höras om de riskerar att skadas samt att deras vilja ska tillmätas betydelse beroende på ålder och mognad (SoL 11:10) synliggör också skillnaden i synsätt på barn och vuxna. Denna skillnad i aktörskap syns även i riktlinjer för utredningar enligt BBIC där socialsekreterare uppmanas att rikta uppmärksamhet mot barns behov men föräldrars förmåga när de bedömer och fattar beslut om barns livssituation (Socialstyrelsen, 2006b).

Socialstyrelsen uttalar dessutom att bedömningar av barns bästa, har en överordnad betydelse i relation till barns vilja. Barns bästa ska bedömas genom en sammanvägning av barns behov och uppfattning om sin situation, föräldrars förmåga och uppfattning om barnens situation, faktorer i familjen och miljön samt utlåtanden från sakkunniga och referenspersoner. Det betyder att barns vilja endast är en del av beslutsunderlaget för att bedöma vad som är bäst för barnet (Socialstyrelsen, 2012). På grund av att vuxna ges rättigheter att besluta om vad som är bäst för barn (Prop.1996/97:124) är barn många gånger beroende av hur socialsekreterare företräder och uppmärksammar deras sak (Mattsson, 2011; Leviner, 2011).

Den rättsliga regleringen ger därmed socialsekreterare rätten att avgöra när barn ska inkluderas och de har tolkningsföreträde vid förståelsen av barns förmåga och vad som är bäst för dem. På så sätt kan socialsekreterare bestämma om och när barns interagerande med sin omgivning ska uppmärksammas, när barns intressen ska få betydelse och hur barns behov ska belysas.

När det handlar om barns hälsa har uppmärksamheten vid barnavårdsutredningar delvis ändrat fokus. Fram till mitten av 1900-talet uppmärksammades hälsa främst som en möjlig orsaksförklaring till avvikande beteende. I början av 2000-talet betonas barns hälsobehov i lagstiftningen. I både barnkonventionen och socialtjänstlagen beskrivs barns rättighet till en så god hälsoutveckling som möjligt genom formuleringar om att barn har rätt till överlevnad och utveckling, såväl fysiskt som socialt (SoL 5:1; UD, 2006). Eftersom socialtjänstlagen är en ramlag och riktlinjer för barnavårdsutredningar är formulerade som mål preciseras dock inte när eller på vilket sätt barns fysiska och psykiska hälsostatus ska inkluderas i analyser och bedömningar av barns behov. Socialtjänstlagens formuleringar förutsätter därmed att socialsekreterare har kunskap om hur de ska gå tillväga för att realisera givna målsättningar (jmf Börjeson, 2006, 2010; Thunved, 2012) som, exempelvis, att se till att barns utveckling, både fysiskt och socialt, är god samt att deras hälsa inte riskerar att skadas.

Uttalanden från Socialstyrelsen i föreskrifter, allmänna råd och handböcker kan dock ge mer vägledning om hur barns hälsa bör uppmärksammas i barnavårdsutredningar. Manualer och mallar, som exempelvis de som återfinns för utredningar enligt BBIC, kan hjälpa socialsekreterare att basera sina ställningstaganden på någon form av systematisk observation (Börjeson, 2010). För utredningar enligt BBIC påtalas-, exempelvis-, vilka sju områden i barns liv som är centrala för att förstå och bedöma barns behov av stöd. Hälsa är ett av dessa områden. Det finns också dokument som specificerar vilka hälsoaspekter som generellt kan vara av betydelse för barns utveckling i olika åldrar. I riktlinjer för BBICutredningar uppmärksammas dock inte hur hälsoaspekter kan bedömas eller analyseras som en del bland andra påverkansfaktorer i enskilda barns liv. Den ger inte heller vägledning i hur avvikelser kan tolkas. Att flera delar av de system som omger ett barn kan vara relevanta eller 
att dessa system samspelar på olika sätt för olika individers utveckling (Bronfenbrenner, 2005) uppmärksammas inte heller. Även om Socialstyrelsen påpekar att den bioekologiska modellen bör kompletteras med utvecklingspsykologisk teori, teorier om barns identitetsutveckling, risk- och skyddsfaktorer, sårbarhet och motståndskraft samt anknytning för att förstå barns utveckling tydliggörs inte hur dessa angivna teorier kan förstås $\mathrm{i}$ förhållande till olika påverkansfaktorer i barns utveckling. Därutöver anges att det är socialsekreteraren som ska bedöma vilka omständigheter som ska belysas och dokumenteras under en utredning (SoL 11:2). I praktiken ges därmed utrymme åt varje enskild kommuns socialtjänst och socialsekreterare att tolka teorierna och dra slutsatser om vad som är viktigt att uppmärksamma i varje enskilt ärende. Den rättsliga regleringen uppmuntrar socialsekreterare att fokusera på barns hälsa som en betydelsefull aspekt $\mathrm{i}$ barns liv. Enskilda socialsekreterare kan dock bestämma om och hur beskrivningar av fysisk och psykisk hälsa ska formuleras beroende på deras individuella uppfattning om hälsoaspekters relevans $i$ argumentationen för de beslut som fattas.

\subsection{Skildringar av barnperspektiv i barnavårdsutredningarna}

\subsubsection{Synliggörande av barns fysiska och psykiska hälsa}

Resultaten från den här avhandlingen visar att socialsekreterare uppmärksammar barns hälsa i större utsträckning i utredningar som är genomförda enligt handläggning- och dokumentationssystemet BBIC (studie 1). Oavsett typ av utredning är dock hälsobeskrivningarna ofta kortfattade och saknar detaljer (studie 1 och 2). Detta medför att förståelsen för vad som specifikt avses blir otydlig. En genomgång av utredningsdokumentationen i de 272 ärendena visar dessutom att det endast i en tredjedel av utredningarna refereras till utlåtanden från medicinsk expertis. Därmed saknas ofta utlåtande som ger ett barnmedicinskt perspektiv på såväl barns fysiska som psykiska hälsostatus, dess orsaker och konsekvenser. När barns hälsa beskrivs är barns psykiska hälsa det som är mest omskrivet (studie 1,2,3) vilket i vissa fall kan bero på att det är det hälsotillståndet som vanligen anges som orsak till utredningens genomförande (studie 2, 3). De få beskrivningar som finns av fysisk hälsa är dock även mer kortfattade och saknar detaljer i jämförelse med beskrivningar av psykisk hälsa (studie 2).

Anledningen till att beskrivningarna av barnen många gånger handlar om problem, både vad gäller barns hälsa och i fråga om andra aspekter av deras livssituation (studie 2,3 och 4) kan vara att de barnavårdsutredningar som ingår i avhandlingens studier är påbörjade efter att en anmälan om oro för sociala problem inkommit till socialtjänsten. När positiva aspekter av barns livssituation synliggörs är de dock också mindre detaljerade (studie 4). Dessutom sätts positiva och problematiska aspekter av barns liv sällan i relation till varandra (studie 2 och 4). Resultaten visar därutöver att när socialsekreterare formulerar analyser och bedömningar av barns psykiska hälsa så kopplas orsaker till ohälsa i regel till föräldrars brister. Betydelsen av andra eventuellt bidragande påverkansfaktorer så som barns fysiska och psykologiska förutsättningar, kamratrelationer, skolsituation och familjens ekonomiska situation nämns däremot sällan (studie 2). Föräldrars förmåga att ta hand om sina barn på ett tillfredställande sätt kan i och för sig vara avgörande för barns hälsa, utveckling och utsatthet 
(Bronfenbrenner, 1979; Gironda m. fl., 2006; Goswani, 2012; Meadows, 2010; Stansfeld, 2006) men problemet med en förklaringsmodell där föräldrars bristande kapacitet betonas i så hög grad är att förståelsen för barns utveckling och behov blir vag. Detta då en ensam faktor sällan kan förklara en problematisk situation (Goodyer, 1995b). Dessutom kan barns hälsoutveckling och konsekvenserna av hälsotillståndet både påverkas av förutsättningar hos den unika individen (Heinonen m. fl., 2009; Sarafino, 2006) och det sociala och kulturella sammanhang som omger barnet (se exempelvis Bolger \& Patterson, 2003; Eriksson \& Lindström, 2006; Gironda m. fl., 2006; Park m. fl., 2009; Power \& Kuh, 2006; Robertson m. fl., 2006; Steptoe, 2006; Shaw m. fl., 2006). Det unika barnet har också sociala relationer och erfarenheter av omsorg och fostran utanför familjen vilket medför att det inte endast är föräldrarna som kan uppfattas som avgörande för deras utveckling (Sommer, 2005). Därutöver samspelar riskfaktorer med skyddande faktorer och olika livsomständigheters påverkan är dessutom unik för varje enskilt barn (Rutter, 1990; Rutter \& Taylor, 2002). Därmed blir det problematiskt om förenklade orsaksförklaringar såväl som ett alltför ensidigt fokus på problem ligger till grund för behovsbedömningar. För att få en förståelse för unika barns behov av stöd och möjligheter till en positiv utveckling behövs därför en analys av barns fysiska och psykiska hälsa i relation till individuella förutsättningar och upplevelser (James m. fl., 1998) men också till de förutsättningar barn som grupp har i det omgivande samhället (Qvortrup m. fl., 1994).

\subsubsection{Synliggörande av barns perspektiv}

I de studerade utredningstexterna finns beskrivningar som utgår ifrån barnens upplevelser om sig själva och sin livssituation. Beskrivningarna varierar men oftast är de förenklade med få detaljbeskrivningar av barnens erfarenheter (studie 4). Skildringarna innehåller information om vissa livsomständigheter men hur barnen uppfattar att dessa förhållanden påverkar dem eller vad de utifrån sin livssituation eventuellt önskar för stöd klarläggs sällan. Detta gäller både i fråga om redogörelser för barns livssituation utifrån de sju behovsområdena i BBICutredningar (studie 4) och i argumentation för beslut (studie 3). I socialsekreterares argumentation för beslut om barns behov skapas förståelsen för barns fysiska och psykiska hälsa dessutom till stor del genom vuxnas perspektiv på barns hälsosituation. Även när barns uppfattningar om sin fysiska och psykiska hälsa presenteras är beskrivningarna oftast kortfattade och de kan exempelvis formuleras som en bekräftelse på vuxnas åsikter (studie 3). Barns upplevelser av sitt eget inflytande på de relationer och de situationer som skapar förutsättningar för deras hälsa beskrivs endast i undantagsfall (studie 3 och 4). Om man vill förstå barns beteende, utveckling och behov är det otillräckligt att kartlägga de förhållanden barn lever under genom andras beskrivningar (Bronfenbrenner, 1979; Meadows, 2010; Rutter \& Taylor, 2002; Woodhead, 1997) på grund av att det inte går att förutsätta hur barns omgivning påverkar det enskilda barnet. Att barns upplevelser framställs i begränsad omfattning och att beskrivningarna är vaga kan därmed innebära att förståelsen för barns behov av stöd begränsas.

När barns agerande skildras så handlar det i de flesta fall om hur deras beteende kan vara en reaktion på den situation de befinner sig i och därmed ett tecken på deras psykiska ohälsa (studie 2). Dessa beskrivningar kan förstås som ett sätt att motivera barns behov av stöd för sin hälsa, men de tydliggör eller förklarar inte barns aktörskap i deras hälsosituation. 
Då bedömningar av barns behov av stöd och skydd formuleras finns det i vissa fall korta angivelser av barns personlighetsdrag, mognad samt förmåga att tala och berätta om sin situation. Däremot framgår sällan under vilka förutsättningar barn har berättat (studie 2 och 3). Om socialsekreterare bygger sina bedömningar av barns mognad och kompetens på de samtal de haft med dem är det betydelsefullt att förstå hur samtalet gått till då innehållet $\mathrm{i}$ deras berättelser kan bero på den intervjuteknik som använts och i vilket sammanhang samtalet genomförts (Cederborg, 2010). Dessutom är det betydelsefullt att uppmärksamma att barns kompetenser kan variera i olika kontexter (James m. fl., 1998; Sommer, 2005).

Socialsekreterares beskrivningar av barns personlighetsdrag och mognad utifrån kvaliteten på det möte de haft med barnen räcker därmed inte för att förklara barns aktörskap eller hur barn hanterar sin hälsosituation. Det finns alltså begränsningar i hur socialsekreterare uppmärksammar barn som subjekt och aktörer när de beskriver deras hälsobehov. För att bemöta barn som subjekt och aktörer bör deras egna upplevelser så väl som deras medskapande av sin livssituation uppmärksammas (James \& Prout, 1997; James m fl., 1998; Medows, 2010; Qvortrup, 1990; Qvortrup m. fl., 1994). Resultaten i avhandlingen tyder på att så inte är fallet och därmed behöver barns status i barnavårdsutredningar höjas. Det kan till och med vara så att det behövs ett förtydligande i den rättsliga regleringen för att åstadkomma förändrade analyser av barn.

Den teoretiska utgångspunkten som definierar barn som subjekt och aktörer lyfter fram barns kompetenser och deras rättigheter till att vara delaktiga (James \& Prout 1997; James m. fl., 1998; Meadows, 2010; Qvortrup m.fl., 1994). Vare sig teorin, lagstiftning eller andra riktlinjer utesluter dock att det är vuxna som har att ta ansvar för och skydda utsatta barn (Qvortrup, 1990; Socialstyrelsen, 1997; SoL 5:1). Det kan därmed finnas ett dilemma att både se till att skydda barns hälsa och utveckling samtidigt som barns åsikter ska bli respekterade. Exempelvis finns svårigheter att bedöma när barn ska ges möjlighet till medbestämmande och när de inte ska det (Aronsson, 2001b; Rasmusson 2011) på grund av avgöranden om när barn är tillräckligt gamla för att förstå och bestämma (James m fl., 1998). Att socialsekreterare bygger sina argument för beslut på vad vuxna anser istället för att skriva fram barns åsikter om sin hälsosituation skulle därmed kunna bero på en ambition att skydda barn ifrån beslutsansvar. Likaså skulle frånvaron av beskrivningar av barns aktörskap kunna vara ett sätt att skydda barn ifrån att framstå som ansvariga för den hälsosituation de befinner sig i. Dessutom kan beskrivningar ha formulerats på det sätt som avhandlingen visar på grund av att bedömningen ska framstå som trovärdig i en juridisk kontext (jmf Hall, 1997). Därmed kan hälsobeskrivningar utifrån barns perspektiv ha valts bort för att de inte framstått som relevanta för den slutgiltiga bedömningen av barnets behov av stöd. På grund av komplexiteten i barns hälsoutveckling är barns egna åsikter och upplevelser dock av betydelse för att få en förståelse för deras unika behov (James m. fl., 1998). Likväl behöver beskrivningar av barn som kompetenta inte medföra att de tillskrivs ansvar för den situation de befinner sig i eller ansvar för att en situation ska förändras (Sommer, 2005). Att förstå barn som subjekt och aktörer behöver inte heller innebära att det endast är barnets åsikt som är viktig att förmedla eller att ett barn nödvändigtvis ger en bättre beskrivning av sin fysiska och/eller psykiska hälsa än exempelvis en läkare eller förälder. Men en utredning som exkluderar barns röster kan anses otillräcklig för att kunna göra en bedömning av barns bästa och ger därmed ett ofullständigt beslutsunderlag (Leviner, 2011). Om barn inkluderas i 
beslutsfattande kan socialtjänsten dessutom få utvecklade möjligheter att ge stöd för barns hälsa då det visat sig finnas större chans att lyckas med insatser där barn varit delaktiga $\mathrm{i}$ besluten. Därutöver kan delaktigheten i sig leda till att barns välmående förbättras (Vis m. fl., 2010).

\section{Slutsatser}

Socialtjänsten är en av de samhälleliga institutioner i Sverige som ska bedriva ett hälsoarbete riktat mot barn. Det handlar både om ett förebyggande arbete för att barn ska behålla en god hälsa men också om att ge stöd till barn med hälsoproblem (Socialstyrelsen, 2006c; 2013a; SoL $5: 1)$.

Resultaten indikerar att informationen i barnavårdsutredningar ger begränsad förståelse för barns fysiska och psykiska hälsostatus och hälsoutveckling. Att beskrivningar av barns aktörskap, hur de upplever att deras situation påverkar dem samt vad de vill och önskar inför framtiden ofta saknas betyder att barns sociala utsatthet inte tydliggörs i den utsträckning som är möjlig (Qvortrup, 1994) trots att syftet med barnavårdsutredningen borde vara det omvända. Att socialsekreterare bör ge barns åsikter utrymme har tidigare konstaterats (Andersson, 1998; Andersson m. fl., 2001; Backe- Hansen \& Havik, 1997; Butler \& Williamson, 1994; Hagbard \& Esping, 1992; Thomas \& Holland, 2010). Som denna avhandling visar är det även betydelsefullt att formulera barns upplevelser på ett innehållsrikt sätt för att deras hälsa ska kunna bli uppmärksammad utifrån barns individuella förutsättningar.

Det kan vara en utmaning att reglera hur socialsekreterare ska förhålla sig till fysisk och psykisk hälsa när de ska bedöma barns utveckling och behov. Eftersom det finns gränser för vad dokumentationen vid en barnavårdsutredning kan innehålla och vad som kan förklaras finns en risk att detaljerade anvisningar leder till standardiserade beskrivningar där det unika i varje barns livssituation tappas bort. Att klienter beskrivs utifrån institutionella ramar istället för utifrån sina unika situationer och förutsättningar är något som tidigare uppmärksammats i socialtjänstens utredningar (Järvinen, 2002; Ponnert, 2007; Roose m. fl., 2009; Swärd, 1993). Även om avhandlingens resultat indikerar att barnperspektivet i både den rättsliga regleringen och genomförandet av barnavårdsutredningar har blivit allt tydligare så behöver socialtjänsten utveckla arbetet med att synligöra barns fysiska och psykiska hälsa i bedömning och analys av barns behov. I riktlinjer för BBIC noteras betydelsen av att uppmärksamma barns hälsa. Den systemteoretiska utgångspunkten som anges för analys tydliggör dock inte hur hälsofaktorer ska kunna analyseras för att få kunskap om dess betydelse för enskilda barn. Att hänvisa till barns hälsoutveckling genom förklaringar som kan kopplas till typisk utveckling ger inte heller tillfredställande förståelse för hur avvikelser ska beskrivas och förstås i de unika barnens liv. Därutöver är riskbedömningar komplicerade att utföra då risk- och skyddsfaktorer påverkar barn olika.

För att öka möjligheterna för utredande socialsekreterare att uppmärksamma individuella barns fysiska och psykiska hälsobehov är det betydelsefullt att ha och inhämta kunskap från flera områden. Förutom egen kännedom om möjliga påverkansfaktorer på barns hälsoutveckling är det viktigt att ta del av den kunskap som finns om barns hälsa inom 
sjukvårdens verksamheter. Dessutom är det angeläget med insikt i komplexiteten i risk- och skyddsbedömningar. En teoretisk förståelse för barn som subjekt och sociala aktörer kan därutöver medföra att barns fysiska och psykiska hälsoutveckling uppmärksammas utifrån barns individuella förutsättningar och upplevelser. Kunskap om hur beskrivningars innehåll och form kan påverka förståelsen för barns livssituation är också betydelsefull för att förstå vilka konsekvenser formuleringar kan få. Om texten i en barnavårdsutredning formuleras så att barns uppfattningar om sin livssituation, dess orsaker, konsekvenser och vad de önskar inför framtiden synliggörs kan förståelsen för barns behov bli tydligare. Om barns individuella åsikter om sin hälsa uppmärksammas även när vuxna tar ansvar för att fatta beslut ökar möjligheterna att argumentera för och besluta om insatser för barns hälsa utifrån deras unika livssituation. Om komplexiteten i barns hälsoutveckling synliggörs kan det dessutom bli tydligare hur föreslagna insatser svarar mot barns behov. Barnperspektivet $i$ barnavårdsutredningarna kan därmed bli tydligare än vad den här avhandlingen visar. 


\section{Fortsatt forskning}

För att utveckla förståelsen för hur socialtjänsten uppmärksammar barn behövs ytterligare studier av socialtjänstens dokumentation under utredning och insatser. Socialsekreterares uppfattningar om hur de förstår aspekter av barns fysiska och psykiska hälsa i bedömningar av barns behov av stöd och skydd behöver också belysas för att utveckla förståelsen för förekomsten av begränsade analyser av dessa aspekter. Dessutom kan insikter om deras föreställningar om vad som ska dokumenteras i en barnavårdsutredning ge en ökad förståelse för varför beskrivningar av barns hälsa formuleras på ett visst sätt. Kunskap om utsatta barns egna upplevelser av sin hälsa och hur den uppmärksammas vid barnavårdsutredningar kan ge utvecklade möjligheter att beskriva hälsa utifrån barns perspektiv. I ovan föreslagna studier skulle exempelvis följande frågeställningar kunna ställas;

\subsection{Intervjuer med socialsekreterare}

Hur uppfattar socialsekreterare betydelsen av barns fysiska och psykiska hälsosituation när de ska fatta beslut om barns eventuella behov av stöd och skydd?

Hur uppfattar socialsekreterare skriftliga konstruktioners betydelse för förståelsen av barnet och dess livssituation?

Hur uppfattar socialsekreterare betydelsen av, och syftet med, att gestalta barns egna upplevelser av sin hälsa och dess orsaker? Vad anser de att barn kan bidra med i en utredning?

Hur hanterar socialsekreterare teoretiska utgångspunkter i det praktiska utredningsarbetet?

Vilken typ av riktlinjer och mallar kan fungera som stöd i utredningsarbetet med ett specifikt fokus på barns hälsa?

\subsection{Intervjuer med barn}

Hur uppfattar barn betydelsen av fysisk och psykisk hälsa i sin livssituation?

Hur upplever barn att socialtjänsten uppmärksammar deras hälsa när de är aktuella för en barnavårdsutredning?

Hur upplever barn de beskrivningar som görs om dem och deras upplevelser av sin hälsa i socialtjänstens utredningar? 


\section{Summary in English}

\subsection{Aim and research questions}

The overall aim of this thesis is to explore how children's physical and psychological health, as well as children's own experiences, are represented in child welfare investigations.

Taken as a whole, the project includes data from 272 social investigations about 259 children. These children were investigated in accordance with Chapter 11,1 and $2 \S \S$, of the Swedish Social Service Act (SoL 2001:453), and in response to a report being submitted to the social service by a third party in a medium-sized town in Sweden. The analytical focus of the thesis is documentation formulated during the investigative process.

The first study adopts a quantitative approach and explores whether the social services, in their investigations of reported children's life situation, describe health aspects, and if so what these aspects are. The analyses in studies two, three and four take a qualitative approach. Thus, the second study investigates the ways in which children's health is explained in the context of reaching conclusions about the concrete needs of children. The third study explores if and how children's voices are represented in the social investigations, specifically in the final part of the reports, where social workers are to justify their decisions. Finally, the fourth study elucidates how social workers in Sweden portray children's perception of themselves as well as their life situation in investigations conducted in accordance with the documentation system, Children's Needs in Focus (BBIC, in Swedish, Barns Behov I Centrum). The specific focus here is on investigations in which initial concerns were raised regarding the children's health. The patterns of results are discussed with reference to legal regulations as well as theories, which identify children as subjects and social actors in their own right.

\subsection{Results and discussion}

\subsubsection{Children's physical and psychological health}

The analyses conducted in this thesis show that social workers report children's health to a greater extent when an investigation has been conducted in accordance with BBIC (study 1). However, regardless of the investigative model used, health aspects are often reported either briefly or only in rather general terms (study 1 and 2). In addition to this, social workers refer to opinions from medical experts in only one third of the 272 investigations examined. As such, many of the case reports produced by social services lack a medical perspective on the physical and psychological health of children. Further psychological health aspects are mentioned more often than physical health in the documentation (study 1, 2 and 3). In some cases the reason for this may be that social workers usually specify psychological health aspects as the cause for conducting the investigations (study 2 and 3). However, both in the social workers' assessments and justifications of their decisions, the few descriptions of physical health that are included are often, when compared to descriptions about psychological health, both sparse and generally lacking details (study 2). As a consequence, an understanding of how a child's health is interwoven within their own life situation and 
how such factors may influence the extent of the support needed could be limited, especially with respect to the child's physical health.

Close attention to problems associated with both the description of children's health and children's experiences of other aspects of their lives could be a consequence of the fact that the investigations are conducted on the basis of concerns raised about children's health and exposure to various other vulnerable life situations (study 2, 3 and 4). When positive aspects are described, these are generally less detailed than descriptions of difficulties (study 4). Meanwhile the ways in which both supportive and problematic aspects interact is seldom explained (study 2 and 4). Furthermore, the results obtained show that, in arguing for the needs of children, social workers often explain children's ill- health as caused by parental misbehaviour. However, the influence of other potential significant factors such as, for example, the child's physical- and psychological condition, how he or she relates to his or her peers, his or her situation at school and the financial situation of the family are barely mentioned (study 2). Parents' capacities to sufficiently take care of their children can be critical for children's development and well-being ( Bronfenbrenner, 1979; Gironda m. fl., 2006; Goswani, 2012; Meadows, 2010; Stansfeld, 2006). However, particularly problematic with assessments that emphasize parental insufficiencies to such a degree is that an understanding of a particular child's health development and needs remains vague. This is because, taken in isolation, one risk factor rarely explains a problematic situation and its possible outcomes (Goodyer, 1995b). More specifically, individual (Heinonen m. fl., 2009; Sarafino, 2006) as well as social and cultural conditions (Bolger \& Patterson, 2003; Eriksson \& Lindström, 2006; Gironda m. fl., 2006; Park m. fl., 2009; Power \& Kuh, 2006; Robertson m. fl., 2006; Steptoe, 2006; Shaw m. fl., 2006) have the potential to influence health development and to help constitute the consequences of health conditions. Additionally, factors such as children's social relations and care outside the family means that parents can no longer be seen as having the sole impact on children's development (Sommer, 2005). Furthermore, risk and supportive aspects interrelate, and each child reacting differently to various life situations (Rutter, 1990; Rutter \& Taylor 2002). It could therefore be problematic if assessments of children's needs are based on overly simplified explanations. Hence, to be able to understand the unique child's potential for positive development and his or her need for support attention ought to turn towards an analysis of children's health with respect to both the particular conditions of the individual child (James m. fl., 1998) as well as wider social conditions that affect children as a group in society more generally (Qvortrup, m. fl., 1994).

\subsubsection{Children's perspective}

In the investigations presented by social workers, while there are descriptions of children's experiences about themselves as well as their life situations, there remain variations in how these descriptions are formulated. Many, for example, include few details about the children's own experiences (study 4). Representations of children's experiences often include information about some circumstances of children's lives, though they lack explanations about children's understanding of how these situations influence them, their opinion about their needs as well as their wishes about support. This is true for both the representation of children's life situation in investigations in accordance with BBIC (study 4) and in the 
arguments presented by individual social workers in justifying the decisions taken (study 3 ). In addition, in social workers' arguments supporting their decisions, children's physical and psychological health is mostly described from the perspective of adults. Even when children's perceptions are presented, their views are sparingly reported and are often used in order to confirm a previous statement or opinion (study 3). Children's experiences of the extent of their own influence over those relations and situations directly affecting them- and which, moreover can account for their health- are only occasionally reported (study 3 and 4). However, to be able to understand children's behaviours, development and needs it is not sufficient to explore others' opinions (Bronfenbrenner, 1979; Meadows, 2010; Rutter \& Taylor, 2002; Woodhead, 1997). Limited and vague descriptions of children's experiences could therefore lead to a limited understanding of a particular child's needs.

Often whenever children's actions are elucidated, children's behaviour is often reported as a reaction to their life situation and thus as a symptom of their problematic psychological health (study 2). These descriptions may work as explanations for children's need of health support. The problem, though, is that they rarely represent children as social actors. Children's personal characteristics, their maturity and their ability to talk about their situation is sometimes acknowledged by social workers in the justifications where they provide for their assessments. However, the conditions under which children have reported their experiences is seldom described (study 2 and 3). If social workers assess children's personal competence based on conversations with them then it is of great importance to understand the content of their narratives in relation to the opportunities with which they are provided via the interviewing technique adopted (Cederborg, 2010). It is also crucial to understand that children's competence varies between contexts (James m. fl., 1998; Sommer, 2005). For that reason, it is not sufficient to explain children's ability to act or to handle their health situation through the quality of meetings that take place between social workers and children.

This means that even though children are to some degree represented as individuals, social workers' attention to children as subjects and social actors is still limited in terms of how their health needs are described. So as to treat children as subjects and social actors in their own right, there must be a need to take into account both their own experiences and their influence on the singularity of their life situation (James \& Prout, 1997; James m fl., 1998; Medows, 2010; Qvortrup, 1990; Qvortrup m. fl., 1994). The analyses conducted indicate that this is not the case which requires children's statues to be raised. To achieve analyses that ascribe to children the status of social actors in their own right additional clarifications in legal regulations may be necessary.

It may be challenging for social workers to make decisions regarding how to describe children's health as well as how to include children's experiences in their investigations. The theoretical position that identifies children as subjects and social actors emphasises children's competences as well as their rights to be involved in those processes that concerns their life (James \& Prout 1997; James m. fl., 1998; Meadows, 2010; Qvortrup m.fl., 1994). Neither this theory, nor legislation and recommendations, exclude however the important responsibility that adults have in protecting vulnerable children (Qvortrup, 1990; National Board of Health and Development, 1997; SoL 5:1). It might therefore be a dilemma for social services to both protect children's health and development as well as take children's opinion into account. For 
example, it is difficult to assess when children should participate in decisions and when they should not (Andersson, 2000; Aronsson, 2001b; Rasmusson 2011). This is because it remains a challenge to determine when, indeed, children are old enough to understand and decide (James et al., 1998). This might imply that the reason why social workers ground their arguments on what adults think, instead of describing the opinions of the child, could be the ambition to protect children from being seen as responsible for the decision made.

Concomitantly, the lack of descriptions of children as social actors could be a way to protect children from being seen as responsible for their own health statuses. Furthermore, another reason for why descriptions seem to be formulated in a certain way could be because assessments in social welfare investigations should appear credible in a legal context (Hall, 1997). This means that social workers might be inclined to deselect descriptions of children's experiences of their health if this does not seem to be relevant for the decisions sought. It is important to elucidate the complexity of children's health development- as well as children's own experiences and opinions- in order to be able to understand their unique needs, however (James m. fl., 1998). Ultimately, interventions seem to be more successful when children have been included in the decision-making process, with participation itself being a contributing factor in improving a child's well-being (Vis m. fl., 2010). 


\section{Tackord}

När nu avhandlingen ska avslutas görs många reflektioner över den tid som gått och vad den här resan fört med sig. Jag har lärt mig väldigt mycket om saker som direkt kan kopplas till avhandlingen men också om mig själv, andra människor och livet i stort. Erfarenheter jag med glädje bär med mig även om det långt ifrån varit en lätt resa.

Det finns många människor att tacka för dessa lärdomar och som även bidragit till att avhandlingen blev färdig.

\section{Ett STORT TACK till....}

...det socialkontor där jag fick tillåtelse att genomföra min datainsamling. Jag fick stor hjälp med att hitta alla dokument och ett mycket trevligt bemötande när jag kopierade, läste och kodade utredningar. Tack!

...mina handledare Ann-Christin Cederborg och Karin Fälth Magnusson. Det hade aldrig gått utan er kunskap och er vägledning. Ann-Christin - jag är glad att du gav mig chansen. Ditt outtröttliga läsande, kommenterande och diskuterande av mina texter är imponerade. Du har gett mycket av din tid och alltid varit tillgänglig även om vi under den största delen av min doktorandtid befunnit oss på olika platser geografiskt. Tack! Karin - du fick mig tidigt att förstå vikten av att ha en tidsplan för avhandlingsarbetet. Din empati och ditt lugn har varit ett stort stöd under de här åren. Tack!

...de arbetskamrater på Linköpings universitet som på olika sätt stöttat mig i detta arbete. Er uppmuntran och era glada tillrop gjorde arbetet lättare att slutföra. Framförallt ett stort tack till Emelie och Josefine. Utan våra samtal om avhandlingsskrivandets med- och motgångar samt "finfikor" på Prego/Zodiaken hade jag aldrig fixat detta. Dessutom var all den praktiska hjälp jag fick av er i slutskedet då av avhandlingen skulle färdigställas ovärderlig. Tack!

...alla på Barn- och ungdomsvetenskapliga institutionen på Stockholms universitet som jag mött på kurser och vid de tillfällen jag varit där för handledning. Ett stort tack för trevliga och spännande samtal. Ett speciellt tack till Johanna för att du diskuterat, reflekterat och kommenterat mitt avhandlingsskrivande. Vi har också delat funderingar om livet utanför universitetets väggar. Du har betytt mycket under de senaste åren!

...Lotta Alm - jag är tacksam för ditt stora kunnande i statistikens värld och ditt medförfattarskap i artikel 1.

...Gisela Eckert, som var opponent på mitt 60 \% seminarium och Björn Blom, som var slutseminarieopponent. Er konstruktiva kritik var till stor hjälp på vägen. 
...Pernilla Leviner - din läsning och dina kommentarer om rättslig reglering i slutet av avhandlingsskrivandet betyder mer än jag tror du förstår. Tack!

... alla fina och betydelsefulla vänner och deras familjer. Anna Cederborg, Jenny \& Robert Helsing, Martin Laps \& Maria Johansson, Malini Sjösten, Irene Magnusson, Helena Holmberg, Josefina Ström, Annica Edoff, Johanna Sjöberg \& Magnus Nilsson. Tack, för ert stöd när livet inte blev som det var tänkt och för att ni delar min glädje när saker till och med blir bättre än jag vågat hoppas. För att ni finns helt enkelt! Tack!

...mina föräldrar Tina och Kjell - med ert sätt att agera och diskutera har ni tydligt förmedlat betydelsen av att ställa upp för personer i samhället som kan behöva stöd. Detta är något jag alltid kommer att bära med mig. Dessutom har jag alltid kunnat vara trygg med att ni finns där för mig, Martin och Kaspar. Tack!

... mina syskon med familjer. Emma, Oscar, Rasmus \& Ronja - ni har ställt upp med allt från att vara barnvakt till husvakt de senaste åren. Jag hoppas ni förstår hur mycket det betyder. Jajje, Linnea, Lo \& Asta - ni inspirerar genom att gå er egen väg och göra saker ni tror på. Sophia och Victor - man blir glad av att vara med er. Tack!

...Gertie \& Rolf, Olla Lotta, Love \& Vanja, Johan \& Victoria - ni engagerar er och finns där för mig, Martin och Kaspar. Tack!

Sist men absolut inte minst

...Martin - du har funnits där, lyssnat, läst, diskuterat och fixat. Framförallt har du trott på mig även när jag själv inte gjort det. Jag älskar dig!

...Kaspar - nu har mamma äntligen skrivit färdigt avhandlingen! Du gör det svåra lätt. Ditt fina brev fick mig att orka även de sista veckorna. Jag älskar dig! 


\section{Referenser}

Alanen, L. (1994). Gender and Generation: Feminism and the "Child Question". I J. Qvortrup, M. Bardy, G. Sgritta, \& H. Wintersberger (Red.), Childhood Matters (ss. 27-42). Aldershot, UK: Ashgate publishing Ltd.

Andershed, H., Andershed, A-K., \& Tuvblad, C. (2013). Psykologiska och biologiska perspektiv på sociala anpassningsproblem. I A. Meuwisse, \& H. Swärd (Red.), Perspektiv på Sociala Problem. (Andra omarbetade utgåvan) (ss.242-260). Stockholm: Natur och Kultur.

Andersson, G. (1998). Föräldrakontakt och familjetillhörighet ur fosterbarns perspektiv. Socialvetenskaplig Tidskrift, 5(1), 3-23.

Andersson, G. (2001). Jag försöker gå framåt men vinden drar mig bakåt - en barndom utan kontinuitet. I K. Aronson (Red.), Haverier i social barnavård? Fem fallstudier (ss. 36-77). Stockholm: Förlagshuset Gothia

Andersson, G. (2003). Utsatta barns hälsa. Socialmedicinsk tidsskrift, 80(5), 453-461.

Andersson, G. (2008). Utsatt barndom-olika vuxenliv. Ett longitudinellt forskningsprojekt om barn $i$ samhällsvård. Stockholm: Stiftelsen allmänna barnhuset.

Andersson, E.H., Ascher, H., Björnberg, U., \& Eastmond, M. (Red.). (2010). Mellan det förflutna och framtiden: asylsökande barns välfärd, hälsa och välbefinnande. Göteborg: Centrum för Europaforskning, Göteborgs universitet.

Andersson, G., \& Hollander, A. (1996). Om barns rätt och barns bästa. I K. Sjögren-Marklund (Red.), Barnet $i$ den sociala barnavården (ss.58-99). Stockholm: Liber

Andersson, G., Aronsson, K., Hessle, S., Hollander, A., \& Lundström, T. (2001). Inledning. I K. Aronsson (Red.), Haverier i social barnavård? Fem fallstudier (ss.22-35). Stockholm: Förlagshuset Gothia.

Andersson, G., \& Rasmusson, B. (2006). Fosterbarns perspektiv på socialtjänstens företrädare. Socialmedicinsk tidskrift, 83(1), 5-15.

Aronsson, K. (2001a). Berättande och sanning. I K. Aronsson (Red.), Haverier i social barnavård? Fem fallstudier (ss.22-35). Stockholm: Förlagshuset Gothia.

Aronsson, K. (2001b). Ideologiska dilemmor och en flyktingflickas röst. I K Aronsson (Red.), Haverier $i$ social barnavård? Fem fallstudier (ss.139-166). Stockholm: Förlagshuset Gothia.

Aronsson, K. (2012). Barnperspektiv. Att utläsa barns utsatthet. Tidskriften Locus 1-2, 100-117. Stockholm. Stockholms universitet.

Backe-Hansen, E., \& Havik, T. (1997). Barnevern på barns premisser. Gyldendal, Norway: Ad Notam.

Barlebo Wennberg, S. (2000). Socialkonstruktivism-positioner, problem och perspektiv. (Översättning Björn Nilsson). Malmö: Liber. 
Barnombudsmannen (BO). (1999). Mänskliga rättigheter för barn: Ett informationsmaterial om FN:s konvention om barnets rättigheter. Stockholm: Förlagshuset Gothia.

Benwell, B., \& Stokoe, E. (2006). Identity and discourse. Edinburgh, UK: Edinburgh University Press.

Bergman, L.R., \& Magnusson, D. (1997). A person-oriented approach of research on developmental psychopathology. Development and Psychopathology, 9, 291- 319.

Bernitz, U., \& Kjellgren, A. (2010). Europarättens grunder (Fjärde upplagan). Stockholm: Nordstedts juridik.

Bernler, G., \& Johansson, L. (1993). Den sociala journalen 1. En studie akter- deras struktur och funktion. Göteborg: Institutionen för socialt arbete, Göteborgs universitet.

Berntsson, L.T., \& Gustafsson, J.E. (2000). Determinants of psychosomatic complaints in Swedish schoolchildren aged seven to twelve years. Scandinavian Journal of Health, 28(4), 281-293.

Blom, B. (1998). Marknadsorientering av socialtjänstens individ-och familjeomsorg. Om villkor, processer och konsekvenser. Umeå: Umeå universitet. Avhandling.

Blom, B. (2006). Marknadsorientering av socialtjänsten- orsaker, motiv och effekter. I O. Grape, B. Blom, \& R. Johansson (Red.), Organisation och omvärld-nyinstitutionell analys av människobehandlande organisationer (ss.173-202). Lund: Studentlitteratur.

Bolger, K.E., \& Patterson, C.J. (2003). Sequelae of child maltreatment: Vulnerability and resilience. I S. Luthar (Red.), Resilience and vulnerability: Adaptation in the context of childhood adversities (ss. 156-181). New York: Cambridge University Press.

Bremberg, S. (1998). Barnrapporten. Kunskapsbaserat folkhälsoarbete för barn och unga i Stockholms län. Stockholm: Centrum för barn och ungdomshälsa Samhällsmedicin Syd, Stockholms läns landsting.

Bronfenbrenner, U. (1979). The Ecology of Human Development. Cambridge, MA: Harvard University Press.

Bronfenbrenner, U. (1999). Environments in developmental perspective: theoretical and operational models. I S.L Friedman, \& T.D Wacus (Red.), Measuring environment across the lifespan: emerging methods and concepts (ss. 3-28). Washington DD: American psychology Association press.

Bronfenbrenner, U. (2005). Ecological Systems Theory. In U. Bronfenbrenner (Red.), Making Human Beings Human. Bioecological perspectives on human development. Thousand Oaks: Sage Publications.

Bronfenbrenner, U., \& Ceci, S.J. (1994). Nature-Nurture Reconceptualized in Developmental Perspective: A Bioecological Model. Psychological Review, 101(4), 568-586.

Burr, V. (2003). Social Constructionism. East Sussex: Routledge.

Butler, I., \& Williamson, H. (1994). Children speak: children, trauma and social work. Harlow, UK: Longman. 
Börjeson, B. (2006). Socialarbetaren och kunskapsneurosen. I B. Blom, S. Morén, \& L. Nygren (Red.), Kunskap i socialt arbete- om villkor processer och användning. Stockholm: Natur och Kultur.

Börjeson, B. (2010). Att förstå socialt arbete. Andra upplagan. Malmö: Liber.

Börjesson, M. (2003). Diskurser och konstruktioner: en sorts metodbok. Lund: Studentlitteratur.

Börjesson, M. (2004). Lådvinsalkoholism. Kategorier som meningsgivare. Kulturella perspektiv, 2, 1225.

Börjesson, M., \& Palmblad, E. (2008). Strultjejer, arbetssökande och samarbetsvilliga. Kategoriseringar och samhällsmoral $i$ socialt arbete Stockholm: Liber.

Cederborg, A-C. (2006). Barns behov I centrum. Perspektiv på socialtjänstens utredningsarbete när barn misstänks fara illa. (SoU-rapport 2006:35). Linköping: Centrum för omsorg vård och socialt arbete. Kommunerna i Linköping, Kinda, Mjölby, Motala, Ydre, Åtvidaberg samt Linköpings universitet.

Cederborg, A-C. (2010). Att intervjua barn. Vägledning för socialsekreterare. Stockholm: Stiftelsen Allmänna barnhuset.

Cederborg, A-C., \& Karlsson, Y. (2001). Omhändertagande med barnets perspektiv. Socialvetenskaplig Tidskrift, 3, 163-179.

Cleaver, H., Walker, S., Scott, J., Cleaver, D., Rose,W., Ward, H., \& Pithouse, A. (2008). The Integrated Children's System. Enhancing Social Work and Inter-Agency Practice. London: Jessica Kingsley Publisher.

Cocozza, M. (2007). The parenting of society. A study of Child Protection in Sweden-from Report to Support. Linköping: Linköpings universitet. Avhandling.

Cocozza, M., Gustafsson, P.A., \& Sydsjö, G. (2006).Child protection in Sweden. Are routine assessment reliable? Acta Paediatrica, 95, 1474-1480. doi: 10.1080/08035250600784352

Collin, F. (1997). Social Reality. London: Routledge.

Dahl, E., Fritzell, J., Lahelma, E., Martikainen, P., Kunst, A., \& Mackenbach, J.P. (2006). Welfare state and health inequalities. I J.S. Siegrist, \& M. Marmot (Red.), Social inequalities in health. New evidence and policy implications (ss.193-222). New York: Oxford University Press.

Dixon, J. (2008). Young people leaving care: health, well-being and outcomes. Child and Family Social Work, 13, 207-217.

Duffy, J., \& Collins M. E. (2010). Macro impacts on caseworker decision-making in child welfare: a cross national comparison. European Journal of Social Work, 13(1), 35-54. doi: $10.1080 / 13691450903135618$

Edvardsson, B. (2012a). En sakligt undermålig vårdnadsutredning med bakomliggande våldshändelser (Rapport). Örebro: Örebro universitet. http://www.divaportal.org/smash/get/diva2:565603/FULLTEXT01.pdf 
Edvardsson, B. (2012b). Socialtjänstens utredningstänkande i barnavårdsutredning enligt BBIC och $i$ två vårdnadsutredningar m.fl. dokument (Rapport). Örebro: Örebro universitet. http://www.diva-portal.org/smash/get/diva2:565602/FULLTEXT01.pdf

Egelund, T. (1997). Beskyttelse av barndommen. Socialforvaltningers risikovurdering och indgrep. Köpenhamn: Hans Rietzel.

Enell, S. (2009). Barnet i utredningen: en uppföljningsstudie om barns ställning i barnavårdsutredningar genomförda i BBIC (FoU-rapport 2009:6). Stockholm: Luppen kunskapscentrum.

English, D.J., Marshall, D.B., \& Steward, A.J. (2003). Effects of family violence on child behaviour and health during early childhood. Journal of Family Violence, 18, 43-57.

Eriksson, M. (2012). Participation for children exposed to domestic violence? Social workers' approaches and children's strategies. European Journal of Social Work, 15(2), 205-221.doi: $10.1080 / 13691457.2010 .513963$

Eriksson, M., \& Lindström, B. (2006). Antonovsky's sense of coherence scale and the relation with health: a systematic review. Journal of Epidemiological \& Community Health, 60, 376-381. doi:10.1136/jech.2005.041616

Falk, L. (2006). 1900-talets barnavård: en studie i två kommuner av lagstadgade professioner hos förtroendevalda i barnavården från början av 1900-talet samt av socialarbetarkårens utveckling under 1900-talets andra hälft. Göteborg: Göteborgs universitet. Avhandling.

Ford, T., Vostanis, P., Meltzer, H., \& Goodman, R. (2007). Psychiatric disorder among British children looked after by local authorities: comparison with children living in private households. British Journal of Psychiatry, 190 (4), 319-325. doi:10.1192/bjp.bp.106.025023

Friis, E. (2003). Sociala utredningar om barn. En rättssociologisk studie av lagstiftningens krav, utredningarnas argumentationer och konsekvenser för den enskilde. Lund: Studentlitteratur.

Gallagher, M., Smith, M., Mark, H., \& Wilkinson, H. (2012). Children and Families' Involvement in Social Work Decision Making. Children \& Society, 26(1), 74-85. http://dx.doi.org/10.1111/j.1099-0860.2011.00409.x

Garralda, M. E. (1994). Chronic Physical Illness and Emotional Disorder in Childhood. Where the brain's not involved, there may still be problems. British Journal of Psychiatry 164, 8-10. doi:10.1192/bjp.164.1.8

Gironda, M.W., Der-Martirosian, C., Abrego, M., Black, E., Leathers, R., \& Atchison, K.A. (2006). A Qualitative Study of Hardiness and Social Support Among Underserved, Inner- City Minority Adults Recovering from Oral Surgery. Social Work in Health Care, 43(4), 29-51. doi: 10.1300/J010v43n04_03

Gleason, T. R., \& Evans, M.E. (2004). Perceived vulnerability: a comparison of parents and children. Journal of Child Health Care, 8(4), 279-287. doi: 10.1177/1367493504047318

Goodyer, I.M. (1995a). Life events and difficulties: Their nature and effects. I M. Goddyer (Red.), The depressed child and adolescent. Developmental and Clinical perspective (ss. 171-193). New York: Cambridge University Press. 
Goodyer, I.M. (1995b). Risk and resilience processes in childhood and adolescence. I B. Lindström, \& N. Spencer (Red.), Social Paediatrics (ss. 433-455). Oxford: Oxford University Press.

Goswani, H. (2012). Social relationships and Children's subjective well-being. Social Indicators Research, 107, 575-588. doi:10.1007/s11205-011-9864-z

Grant, T., Huggins, J., Graham, J.C., Ernst, C., Whitney, N., \& Wilson, D. (2011). Maternal substance abuse and disrupted parenting: Distinguishing mothers who keep their children from those who do not. Children and Youth Services Review, 33, 2176-2185. doi:10.1016/j.childyouth.2011.07.001

Guglani, S., Rushton, A., \& Ford, T. (2008). Mental health and educational difficulties in children in contact with Children's social services. Child and Family Social Work, 13, 188-196. doi:10.1111/j.1365-2206.2007.00531.x

Hagbard, S., \& Esping, U. (1992). Med barns ögon: om ett barnrelaterat förhållningssätt $i$ familjehemsvården. Stockholm: Allmänna barnhuset.

Halfon, N., \& Hochstein, M. (2002). Life course health development: an integrated framework for developing health, policy and research, The Millbank Quarterly, 80(3), 433-479. doi:10.1111/1468-0009.00019

Hall, C. (1997). Social work as narrative: Storytelling and persuasion in professional texts. Ashgate: Aldershot.

Hall, C., Slembrouck, S., \& Sarangi, S. (2006). Language practices in social work. Categorisation and accountability in child welfare. Abington: Routledge.

Halldén, G. (2003). Barnperspektiv som ideologiskt eller metodologiskt begrepp. Pedagogisk Forskning i Sverige, 8(1-2), 12-23.

Heinonen, T., Metteri, A., \& Leach, J. (2009). Applying health determinants and dimensions in social work practice. European Journal of Social Work, 12(2), 139-153.

doi:10.1080/13691450802567424

Helm, D. (2011). Judgments or assumptions? The role of analysis in assessing children and young people's needs. British Journal of Social Work, 41, 894-911. doi:10.1093/bjsw/bcr096

Hennum, N. (2011). Controlling children's lives: covert messages in child protection service reports. Child and Family Social Work, 16(3), 336-344. doi:10.1111/j.1365-2206.2010.00744.x

Hill, C., \& Thomson, M. (2003). Mental and physical health co-morbidity in looked after children. Clinical Child Psychology Psychiatry, 18(3), 315-321. doi:10.1177/1359104503008003003

Holland, S. (2001). Representing Children in Child Protection Assessments. Childhood, 8(3), 322-339. doi: $10.1177 / 0907568201008003002$

Holland, S. (2004). Child and family assessment in Social work practice. London: Sage.

Hollander, A. (1985). Omhändertagande av barn: en studie av barnavårdsmål vid förvaltningsdomstolarna åren 1974, 1977 och 1982. Stockholm: Aktuell juridik. 
Hollander, A. (2001). En mammas motstånd - om samtycke vid ett omhändertagande. I K. Aronson (Red.), Haverier i social barnavård? Fem fallstudier. Stockholm: Förlagshuset Gothia.

Holstein, J., \& Miller, G. (1993). Social Constructionism and Social Problems Work. I J. Holstein, \& G. Miller (Red.), Reconsidering Social Constructionism (ss.151-172). New York, US: Aldine de Gruyer

Horwath, J. (2011). See the practitioner, See the child: The Framework for the assessment of children in need and their families ten years on. British Journal of Social Work, 41, 6, 1070-1087. doi:10.1093/bjsw/bcq137

Hydén, L-C. (1991). Barnavårdsutredningen som identitet. Rapport 1991:6. Stockholm: Forsknings- och utvecklingsbyrån Stockholms socialförvaltning.

Hydén, L-C. (1995). Det sociala misslyckandet som berättelse- att återställa den moraliska ordningen. Socialvetenskaplig Tidsskrift, 3, 194-207.

James, A., Jenks, C., \& Prout, A. (1998). Theorizing Childhood. Cambridge, UK: Polity Press.

James, A., \& Prout, A. (Red.). (1997). Constructing and reconstructing childhood: contemporary issues in the sociological study of childhood. (Andra utgåvan). New York: Routledge Falmer.

Jonson-Reid, M., Kim, J., Barolak, M., Citerman, B., Laudel, C., Essma, A., Fezzi, N., Green, D., Kontak, D., Mueller, N., \& Thomas, C. (2007). Maltreated Children in Schools: The Interface of School Social Work and Child Welfare. Children \& Schools, 29(3), 182-191. doi:10.1093/cs/29.3.182

Järvinen, M.(2002). Mötet mellan klient och system - om forskning i socialt arbete. Dansk Sociologi, 13(2), 73-84.

Kaldal, A. (2010). Parallella processer: en rättsvetenskaplig studie av riskbedömningar $i$ vårdnads- och LVU-mål. Stockholm: Jure. Avhandling

Kawachi, I., Subramanian, S.V., \& Almeida-Filho, N. (2002). A glossary for health inequalities. Journal of health inequalities, 56, 647-652. doi:10.1136/jech.56.9.647

Kling, S. (2010). Fosterbarns hälsa- det medicinska omhändertagandet av samhällsvårdade barns hälsa i Malmö (Rapport), Göteborg: Nordiska Högskolan för Folkhälsovetenskap. http://www.socialstyrelsen.se/psykiskhalsa/barnspsykiskahalsa/forskningochutvardering/Docum ents/Fosterbarns_h\%C3\%A4lsa_Slutrapport.pdf

Kristofersen, L. B. (2005). Barnevernbarnas helse: Utforhet och dodelighet i perioden 1990- 2002 (NIBR-rapport 2005:12). Oslo: Norsk Institut for by- och regionsforskning. http://www.nibr.no/filer/2005-12.pdf

Kähkönen, P. (1999). The assessment of parenting in child welfare practice. Children and Youth Services Review, 21(7), 581-603. http://dx.doi.org/10.1016/S0190-7409(99)00040-7

Köhler, L. (2004). Indikationer för barns hälsa i Sverige- bidrag till ett kommunalt barnindex. Stockholm: Rädda Barnen. 
Lamb, M.E., \& Fauchier, A. (2001). The effects of question type on self-contradiction by children in the course of forensic interviews. Applied Cognitive Psychology 15, 483-491. doi:10.1002/acp.726

Lamb, M.E., Hershkowitz, I., Sternberg, K. J., Boat, B., \& Everson, M. D. (1996). Investigative interviews of alleged sexual abuse victims with and without anatomical dolls. Child Abuse \& Neglect, 20, 1239-1247. http://dx.doi.org/10.1016/S0145-2134(96)00121-4

Leeson, C. (2007). My life in care: experiences of non-participation in decision-making processes. Child and Family Social Work, 12, 268-277. doi: 10.1111/j.1365-2206.2007.00499.x

Leviner, P. (2011). Rättsliga dilemman i socialtjänstens barnskyddsarbete. Stockholm: Jure. Avhandling.

Leviner, P. (2012). Barnperspektiv i socialtjänstens barnskyddsarbete - samtal med barn och bedömningar av barns bästa. I L. Rydberg-Wellander (Red.), Rätt, social utsatthet och samhälleligt ansvar. Festskrift till Anna Hollander (ss. 273-287). Stockholm: Nordstedts juridik.

Leviner, P., \& Eneroth, E. (2012). Socialtjänstens ansvar för barn och unga. I Å. Alfvengren, \& E. Eneroth (Red.), Juridik för socialt arbete (ss. 105-144). Malmö: Gleerups.

Lindell, C., \& Svedin, C-G. (2004). Social services provided for physically abused children in Sweden: background factors and interventions. International Journal of Social Welfare, 13(4), 340-349. doi:10.1111/j.1468-2397.2004.00330.x

Little, M., Axford, N., \& Morpeth, L. (2004). Research review: risk and protection in the context of services for children in need. Child and Family Social Work, 9, 105-117. doi:10.1111/j.1365-2206.2004.00296.x

Ljung, T., \& Friberg, P. (2004). Stressreaktionernas biologi. Läkartidningen, 12(101), 1089-1094.

Lundberg, O., Åberg Yngwe, M., Kölegård Stjärne, M., Björk, L., \& Fritzell, J. (2008). The Nordic experience: welfare states and public health (NEWS). Stockholm: Stockholm universitet/Karolinska Institutet, Centre for Health Equity Studies (CHESS).

Lundström, T. (1993). Tvångsomhändertagande av barn: en studie av lagarna, professionerna och praktiken under 1900-talet. Stockholm: Stockholms Universitet. Avhandling.

Lundström, T. (1996). Den sociala barnavården. I K. Sjögren-Marklund (Red.), Barnet i den sociala barnavården (ss.11-57). Stockholm: Liber.

Lundström,T., \& Sallnäs, M. (2003). Klass, kön och etnicitet i den sociala barnavården. Socialvetenskaplig tidskrift, 10(2-3), 193-213.

Mason, J. (2008). A Children's Standpoint: Needs in Out-of-Home Care. Children \& Society, 22, 358369. doi:10.1111/j.1099-0860.2007.00115.x

Mattsson, T. (2002). Barnet och rättsprocessen. Rättssäkerhet, integritetssydd och autonomi i samband med beslut om tvångsvård. Lund: Juristförlaget. Avhandling.

Mattsson, T. (2006). Barnet som subjekt och aktör: en rättslig studie om barn i familjehem. Uppsala: Iustus. 
Mattsson, T. (2011). Lagen- några utgångspunkter. I T. Hjort (Red.), Social barnavård - några utmaningar. Glimtar från forskning ur olika perspektiv (Meddelanden från socialhögskolan 2011:6) (ss. 5-14). Lund: Lunds universitet.

McAuley, C., \& Davis, T. (2009). Emotional well-being and mental health of looked after children in England. Child and Family Social Work, 14, 147-155. doi:10.1111/j.1365-2206.2009.00619.x

McCann, J.B., James, A., Wilson, S., \& Dunn, G. (1996). Prevalence of psychiatric disorder in young people in the care system. British Medical Journal, 313, 1529-1530.

McCue Horwitz, S.M., Hurlburt, M.S., Heneghan, A., Zhang, J., Rolls-Reutz, J., Fisher, E., Landsverk, J., \& Stein, R.E.K. (2012). Mental Health Problems in Young Children Investigated by U.S. Child Welfare Agencies. Journal of the American Academy of Child \& Adolescent Psychiatry, 51(6), 572-581. doi:10.1016/j.jaac.2012.03.006

McLeod, E. \& Bywaters, P. (2000). Social Work, Equality and Health. London: Routledge.

Meadows, S. (2010). The Child as Social person. London: Routledge.

Meuwisse, A., Sunesson, S., \& Swärd, H. (2006). Socialt arbete. En grundbok. (Andra upplagan). Stockholm: Natur och Kultur.

Meuwisse, A., \& Swärd, H. (2013). Introduktion. Vad är ett socialt problem? I A. Meuwisse, \& H. Swärd (Red.), Perspektiv på sociala problem (Andra omarbetade utgåvan) (ss. 23-56). Stockholm: Natur och Kultur.

Nybom, J. (2005). Visability and 'child view' in the assessment process of social work: cross-national comparisons. International Journal of Social Welfare, 14, 315-325. doi:10.1111/j.13696866.2005.00374.x

Ohrlander, K .(1992). I barnens och nationens intresse. Socialliberal reformpolitik 1903-1930. Stockholm: Almquist \& Wicksell förlag.

Orbach, Y., \& Lamb, M.E. (1999). Assessing the accuracy of a child's account of sexual abuse: A case study. Child Abuse and Neglect, 23, 91-98. http://dx.doi.org/10.1016/S0145-2134(98)00114-8

Orbach, Y., \& Lamb, M.E. (2001). The relationship between within-interview contradictions and eliciting interviewer utterances. Child Abuse and Neglect, 25, 323-333. http://dx.doi.org/10.1016/S0145-2134(00)00254-4

Park, K., Kersey, M., Geppert, J., Story, M., Cutts, D., \& Himes, J.H. (2009). Household food insecurity is a risk factor for iron-deficiency anaemia in a multi-ethnic, low-income sample of infants and toddlers. Public Health Nutrition: doi:10.1017/S1368980009005540

Parker, R., Ward, H., Jackson, S., Aldgate, J., \& Wedge, P. (1991). Looking After Children: Assessing Outcomes in Child Care. The report of an independent working party established by the Department of Health. London: HMSO.

Payne, M. (2008). Modern teoribildning i socialt arbete (Andra svenska utgåvan). Översättning Björn Nilsson. Stockholm: Natur och Kultur. 
Pelcovitz, D., Kaplan, S.J., DeRosa, R.R., Mandel, F.S., \& Salzinger, S. (2000). Psychiatric disorders in adolescents exposed to violence and physical abuse. American Journal of Orthopsychiatry, 70, 360-369. doi:10.1037/h0087668

Ponnert, L. (2007). Mellan klient och rättssystem. Tvångsvård av barn och unga ur socialsekreterares perspektiv. Lund: Lunds universitet. Avhandling.

Potter, J. (1996). Representing reality: Discourse, rhetoric and social construction. London: Sage publication.

Potter, J. (2003). Discourse analysis and discursive psychology. I P.M. Camic, J.E. Rhodes, \& L. Yardley (Red.), Qualitative research in psychology: Expanding perspectives in Methodology and design (pp. 73-94). Washington DC, US: American Psychological Association.

Potter, J., \& Wetherell, M. (1987). Discourse and social psychology. Beyond attitudes and behavior. London: Sage publications.

Potter, J., \& Wetherell, M. (1995). Discourse Analysis. I A.J. Smith, R. Harré, \& L. Van Langenhove (Red.), Rethinking methods in psychology (ss.80-92). London: Sage Publication.

Power, C., \& Kuh, D. (2006). Life course development in unequal health. I J.S. Siegrist, \& M. Marmot (Red.), Social inequalities in health. New evidence and policy implications (ss.27-53). New York: Oxford University Press.

Prout, A. (2005). The future of childhood: towards the interdisciplinary study of children. Abingdon: Routledge Falmer.

Qvortrup, J. (1990). Childhood as social phenomenon. An introduction to a series of National Reports. Esbjerg: University Center of Jutland.

Qvortrup, J. (1994). Introduction. I J.Qvortrup, M. Bardy, G. Sgritta, \& H. Wintersberger, (Red.), Childhood matters: Social theory, practice and politics. Avebury: Aldershot.

Qvortrup, J. (1997). A voice for children in statistical and social accounting: a plea for children's right to be heard. I A. James, \& A. Prout. Constructing and reconstructing childhood. Contemporary issues in the sociological study of childhood (Andra utgåvan) (ss.85-106). New York: Routledge Falmer.

Qvortrup, J., Bardy, M., Sgritta, G., \& Wintersberger, H. (Red.). (1994). Childhood matters: Social theory, practice and politics. Avebury: Aldershot.

Rangel, L., Garralda, M.E., Hall, A., \& Woodham, S. (2003). Psychiatric adjustment in chronic fatigue syndrome of childhood and in juvenile idiopathic arthritis. Psychological Medicine, 33(2), 289297. doi:10.1017/S0033291702006529

Rasmusson, B. (2004). Barnavårdsutredningar på nya grunder (Rapport från socialhögsskolan 2004:1). Lund: Lunds universitet.

Rasmusson, B. (2011). Barnperspektivet och barns delaktighet. I T.Hjort (Red.), Social barnavård några utmaningar. Glimtar från forskning ur olika perspektiv (Meddelanden från socialhögskolan 2011:6) (ss. 15-27). Lund: Lunds universitet. 
Robertson, A., Brunner, E., \& Sheiham, A. (2006). Food is a political issue. I M. Marmot, \& R.G. Wilkinson (Red.), Social determinants of health. (Andra utgåvan) (ss. 172-195). New York: Oxford University Press.

Romans, S.E., Martin, J., \& Mullen, P.E. (1997). Childhood sexual abuse and later psychological problems: neither necessary, sufficient nor acting along. Criminal Behaviour and Mental Health, 7, 327 - 338. doi:10.1002/cbm.193

Roose, R., Mottart, A., Dejonckheere, van Nijnatten, C., \& De Bie, M. (2009). Participatory social work and report writing. Child \& Family Social Work, 14, 322-330. doi:10.1111/j.1365-2206.2008.00599.x

Rutter, M. (1990). Psychosocial resilience and protective mechanism. I J. Rolf, A.S. Masten, D. Cicchetti, K.H. Nuechterlein, \& S. Wintraub (Red.), Risk and Protective factors in the development of psychopathology (ss.181-214). Cambridge: Cambridge University Press.

Rutter, M., \& Tylor, E. (2002). Clinical assessments and diagnostic formulation. In M. Rutter, \& E. Taylor (Red.), Child and adolescent psychiatry (ss.18-31) (Fjärde upplagan). Chichester: Blackwell Publishing.

Röbäck, K., \& Höjer, I. (2009). Constructing children's views in the enforcement of contact orders. International Journal of Children's Rights, 17, 663-680. doi:10.1163/157181808X401457

Sarafino, E.P. (2006). Health psychology. Biopsychosocial interactions (Femte utgåvan). New York: John Wiley \& Sons.

Schumacher, J.A., Slep, A., Smith, M., \& Heyman, R.E. (2001). Risk factors for child neglect. Aggression and violent behaviour, 6, 231-254. http://dx.doi.org/10.1016/S1359-1789(00)00024-0

Shaw, M., Dorling, D., \& Smith, G.D. (2006). Poverty, social exclusion and minorities. I M. Marmot, \& R.G. Wilkinson (Red.), Social determinants of health (Andra upplagan) (ss. 196-223). New York: Oxford University Press.

Silverman, D. (2006). Interpreting qualitative data (Tredje upplagan). London: Sage publications.

Socialdepartementet. (2004). Ekonomiskt utsatta barn (Ds 2004:41). Stockholm: Socialdepartementet.

Socialstyrelsen. (1997). Barnets Bästa i främsta rummet. FN:s konvention om barnets rättigheter $i$ Sverige (SOU 1996:116). Stockholm: Socialstyrelsen.

Socialstyrelsen. (2000). Dartingtonprojektet: en försöksverksamhet för att stärka och utveckla familjevården (SoS- rapport 2000:2). Stockholm: Socialstyrelsen.

Socialstyrelsen. (2004). Socialt arbete med barn och unga i utsatta situationer. Förslag till kompetensbeskrivning. Stockholm: Socialstyrelsen.

Socialstyrelsen. (2006a). Grundbok Barn behov i Centrum (BBIC). Stockholm: Socialstyrelsen.

Socialstyrelsen. (2006b). Barn och unga i socialtjänsten. Utreda, planera och följa upp beslutade insatser. Stockholm: Socialstyrelsen. 
Socialstyrelsen. (2006c). Personalens kompetens vid handläggning och uppföljning av ärenden som rör barn och unga (SOSFS 2006:14). Stockholm: Socialstyrelsen.

Socialstyrelsen. (2006d). Handläggning och dokumentation av ärenden som rör barn och unga. (SOSFS 2006:12). Stockholm: Socialstyrelsen.

Socialstyrelsen. (2006e). Socialstyrelsens föreskrifter och allmänna råd (SOSFS 2006:5) om dokumentation vid handläggning av ärenden och genomförande av insatser enligt SoL, LVU, LVM och LSS. Stockholm: Socialstyrelsen.

Socialstyrelsen. (2008). Social barnavård i förändring. Slutrapport från BBIC-projektet. Stockholm: Socialstyrelsen.

Socialstyrelsen. (2009a). Studiematerial Barns behov i centrum (BBIC). Stockholm: Socialstyrelsen.

Socialstyrelsen. (2009b). Analys, bedömningar och beslut i utredningar enligt BBIC. Stockholm: Socialstyrelsen.

Socialstyrelsen. (2010). Handläggning och dokumentation inom socialtjänsten. Stockholm: Socialstyrelsen.

Socialstyrelsen. (2012). Dokumentation av barnets bästa inom socialtjänsten. Stockholm: Socialstyrelsen.

Socialstyrelsen. (2013a). Placerade barns skolgång och hälsa - ett gemensamt ansvar. Stockholm: Socialstyrelsen.

Socialstyrelsen. (2013b). Barns och ungas hälsa, vård och omsorg 2013. Stockholm: Socialstyrelsen.

Sommer, D. (2005). Barndomspsykologi. Utveckling $i$ en förändrad värld (Andra reviderade utgåvan). Stockholm: Liber.

Spaccarelli, S., \& Kim, S. (1995). Resilience criteria and factors associated with resilience in sexually abused girls. Child Abuse and Neglect, 19(9), 1171-1182. http://dx.doi.org/10.1016/0145-2134(95)00077-L

Stansfeld, S.A. (2006). Social support and social cohesion. I M. Marmot, \& R.G. Wilkinson (Red.), Social determinants of health (Andra utgåvan) (ss. 148-171). New York: Oxford University Press.

Statens Folkhälsoinstitut. (2011a). Barns och ungas hälsa. Kunskapsunderlag för Folkhälsopolitisk rapport 2010. Östersund: Statens Folkhälsoinstitut.

Statens Folkhälsoinstitut. (2011b). Social health inequalities in Swedish children and adolescents- $a$ systematic review (2011:11) (Andra utgåvan). Östersund: Statens Folkhälsoinstitut.

Stattin, H., \& Magnusson, D. (1996). Antisocial development: a holistic approach. Development and psychopathology, 8, 617-645. http://dx.doi.org/10.1017/S0954579400007331

Steptoe, A. (2006). Psychobiological processes linking socio-economic position with health. I J. Siegrist, \& M. Marmot (Red.), Social inequalities in health: new evidence and policy implications (ss.101-126). New York: Oxford University Press. 
Sundelin, C. (1995). Socioekonomiska faktorers betydelse för barns hälsa och utveckling. Socialmedicinsk tidsskrift, 8, 320-324.

Sundell, K., Egelund T., Andrée Löfholm, C., \& Kaunitz, C. (2008). Barnavårdsutredningar: en kunskapsöversikt. Stockholm: Gothia.

Sundell, K., Vinnerljung, B., Andrée Löfholm, C., \& Humlesjö, E. (2004). Socialtjänstens barn- hur många är de, vilka är insatserna, hur ofta återaktualiseras de och vad händer dem $i$ vuxen ålder? (FoU-rapport 2004:4). Stockholm: Forsknings- och Utvecklingsenheten, Stockholms stad.

Sundkvist, M. (1994). De vanartade barnen. Mötet mellan barn, föräldrar och Norrköpings barnavårdsnämnd 1903-1925. Falkenberg: Hjelms.

Swärd, H. (1993). Mångenstädes svårt vanartad. Om problemen med det uppväxande släktet. Floda: Zenon förlag.

Takayama, J.I., Wolfe, E., \& Coulter, K.P. (1998). Relationship between reasons for placement and medical findings among children in foster care. Pediatrics, 101(2), 201-207. doi:10.1542/peds.101.2.201

Taylor, S. (2001). Locating and conducting discourse analytic research. I M. Wetherell, S. Taylor, \& S. J. Yates (Red.), Discourse as data- a guide for analysis (ss.5-48). London: Sage publications.

Thomas, J., \& Holland, S. (2010). Representing Children's Identities in Core Assessments. British Journal of Social Work, 40(8), 2617-2633. doi:10.1093/bjsw/bcp154

Thunved, A. (2012) Nya sociallagarna med kommentarer, lagar och förordningar som de lyder den 1 januari 2012 (25:e uppl.). Stockholm: Norstedts juridik.

Utrikesdepartementet (UD) (2006). Mänskliga rättigheter. Konventionen om barnets rättigheter. Författare: Thomas Hammarberg, uppdaterad av UD:s enhet för folkrätt, mänskliga rättigheter och traktatsrätt. Stockholm: Regeringskansliet.

Vinnerljung, B. (2006). Fosterbarn som unga - en översikt av resultat från några nationella registerstudier. Socialmedicinsk tidskrift, 83(1), 23-35.

Vinnerljung, B., Hjern, A., \& Lindblad, F. (2006). Suicide attempts and severe psychiatric morbidity among former child welfare clients- a national cohort study. Journal of Child Psychology and Psychiatry, 47(7), 723-733. doi: 10.1111/j.1469-7610.2005.01530.x

Vis, S.A, Strandbu, A, Holtan, A., \& Thomas, N. (2011). Participation and health- a research review of child participation in planning and decision-making. Child \& Family Social Work, 16(3), 325 335. doi:10.1111/j.1365-2206.2010.00743.x

Von Koch, R. (1945). Samhällets barnavård (Fjärde upplagan). Stockholm: Nordstedts och söner.

Voydanoff, P. (1990). Economic distress and family relations: A review of the eighties. Journal of Marriage and the Family, 52, 1099-1115. 
Wan, J.J., Morabito, D.J., Khaw, L., Knudson, M.M., \& Dicker, R.A. (2006). Mental illness as an independent risk factor for unintentional injury and injury recidivism. Journal of Trauma, 61(6), 1299-1304.

Wetherell, M. (2001). Themes in discourse Research: The case of Diana. I M. Wetherell, S. Taylor, \& S.J. Yates (Red.), Discourse theory and practice. A reader. London: Sage publication.

Wetherell, M., \& Potter, J. (1992). Mapping the language of racism. New York: Colombia University Press.

Wetherell, M., Taylor, S., \& Yates, S.J. (Red.). (2001). Discourse theory and practice. A reader. London: Sage publication.

Wiklund, S. (2006). Signs of child maltreatment. The extent and nature of referrals to Swedish child welfare agencies. European Journal of Social Work, 9(1), 39-58. http://dx.doi.org/10.1080/13691450500480615

Wiklund, S. (2008). Individ- och familjeomsorgens barnavårdsarbete. I A.. Bergmark, T.Lundström, R. Minas, \& S. Wiklund (Red.), Socialtjänsten i blickfånget. Organisation, resurser, insatser. Exempel från arbete med barn och ungdom, försörjningsstöd, missbruk (ss.105-140). Stockholm: Natur och Kultur.

Woodhead, M. (1997). Psychology and the cultural construction of children's needs. I A. James, \& A. Prout (Red.), Constructing and reconstructing childhood: contemporary issues in the sociological study of childhood (Andra utgåvan)(ss.63-84). New York: Routledge Falmer.

Xu, R., \& Wunsch, D. (2009). Clustering. Hoboken, NJ: John Wiley \& Sons.

Östberg, F. (2010). Bedömningar och beslut: från anmälan till insats i den sociala barnavården. Stockholm: Stockholms universitet. Avhandling.

\section{Propositioner}

Prop. 1979/80:1 Om socialtjänsten.

Prop. 1996/97:124 Ändring i socialtjänstlagen

Prop. 2004/05:39 Kvalitet, dokumentation och anmälningsplikt i lagen (1993:387) om stöd och service till vissa funktionshindrade (LSS).

Prop. 2012/13:10 Stärkt stöd och skydd till barn och unga.

Svensk författningssamling (SFS)

Föräldrabalken (1949:381)

Kommunallag (1991:900)

Lag (1990:52) med särskilda bestämmelser för vård av unga

Socialtjänstlagen (2001:453)

Elektroniska källor

http://www.Socialstyrelsen.se/barnochfamilj/bbic/bbic-konceptet\#anchor_ 1, 130421 


\section{Articles}

The articles associated with this thesis have been removed for copyright reasons. For more details about these see:

http://urn.kb.se/resolve?urn=urn:nbn:se:liu:diva-102187 


\section{Studies from the Swedish Institute for Disability Research}

1. Varieties of reading disability

Stefan Gustafson

ISBN 91-7219-867-2, 2000

2. Cognitive functions in drivers with brain injury - anticipation and adaptation

Anna Lundqvist

ISBN 91-7219-967-9, 2001

3. Cognitive deafness

Ulf Andersson

ISBN 91-7373-029-7, 2001

4. Att lära sig leva med förvärvad hörselnedsättning sett ur par-perspektiv

Carin Fredriksson

ISBN 91-7373-105-6, 2001

5. Signs, Symptoms, and Disability Related to the Musculo-Skeletal System

Gunnar Lundberg

ISBN 91-7373-160-9, 2002

6. Participation - Ideology and Everyday Life

Anette Kjellberg

ISBN 91-7373-371-7, 2002

7. Föräldrar med funktionshinder - om barn, föräldraskap och familjeliv

Marie Gustavsson Holmström

ISBN 91-7203-500-5, 2002

8. Active wheelchair use in daily life

Kersti Samuelsson

ISBN 91-7373-196-X, 2002

9. Två kön eller inget alls. Politiska intentioner och vardagslivets realiteter i den arbetslivsinriktade rehabiliteringen

Marie Jansson

ISBN 91-7373-568-X, 2003

10. Audiological and cognitive long-term sequelae from closed head injury

Per-Olof Bergemalm

ISBN 91-7668-384-2, 2004

11. Att vara i särklass - om delaktighet och utanförskap i gymnasiesärskolan Martin Molin

ISBN 91-85295-46-9, 2004 
12. Rättvis idrottsundervisning för elever med rörelsehinder - dilemma kring omfördelning och erkännande

Kajsa Jerlinder

Licentiate Degree, 2005

13. Hearing impairment and deafness. Genetic and environmental factors interactions - consequences. A clinical audiological approach

Per-Inge Carlsson

ISBN 91-7668-426-1, 2005

14. Hearing and cognition in speech comprehension. Methods and applications Mathias Hällgren

ISBN 91-85297-93-3, 2005

15. Living with deteriorating and hereditary disease: experiences over ten years of persons with muscular dystrophy and their next of kin

Katrin Boström

ISBN 91-7668-427-x, 2005

16. Disease and disability in early rheumatoid arthritis

Ingrid Thyberg

ISBN 91-85299-16-2, 2005

17. "Varför får jag icke följa med dit fram?" Medborgarskapet och den offentliga debatten om dövstumma och blinda 1860-1914

Staffan Bengtsson

ISBN 91-85457-06-X, 2005

18. Modalities of Mind. Modality-specific and nonmodality-specific aspects of working memory for sign and speech

Mary Rudner

ISBN 91-85457-10-8, 2005

19. Facing the Illusion Piece by Piece. Face recognition for persons with learning disability

Henrik Danielsson

ISBN 91-85497-09-6, 2006

20. Vuxna med förvärvad traumatisk hjärnskada - omställningsprocesser och konsekvenser i vardagslivet. En studie av femton personers upplevelser och erfarenheter av att leva med förvärvad traumatisk hjärnskada

Thomas Strandberg

ISBN 91-7668-498-9, 2006

21. Nycklar till kommunikation. Kommunikation mellan vuxna personer med grav förvärvad hjärnskada och personernas närstående, anhöriga och personal

Pia Käcker

ISBN 978-91-85715-88-6, 2007 
22. "Aspergern, det är jag". En intervjustudie om att leva med Asperger syndrom

Gunvor Larsson Abbad

ISBN 978-91-85831-43-2, 2007

23. Sounds of silence - Phonological awareness and written language in children with and without speech

Janna Ferreira

ISBN 978-91-85895-74-8, 2007

24. Postponed Plans: Prospective Memory and Intellectual Disability

Anna Levén

ISBN 978-91-85895-57-1, 2007

25. Consequences of brain tumours from the perspective of the patients and of their next of kin

Tanja Edvardsson

ISBN 978-91-7668-572-3, 2008

26. Impact on participation and service for persons with deafblindness

Kerstin Möller

ISBN 978-91-7668-595-2, 2008

27. Approaches to Audiological Rehabilitation with Hearing Aids: studies on prefitting strategies and assessment of outcomes

Marie Öberg

ISBN 978-91-7393-828-0, 2008

28. Social Interaction and Participation in Activities of Everyday Life Among Persons with Schizophrenia

Maria Yilmaz

Licentiate Degree, 2009

29. Focus on Chronic Disease through Different Lenses of Expertise

Towards Implementation of Patient-Focused

Decision Support Preventing Disability:

The example of Early Rheumatoid Arthritis

Örjan Dahlström

ISBN 978-91-7393-613-2, 2009

30. Children with Cochlear Implants: Cognition and Reading Ability

Malin Wass

ISBN: 978-91-7393-487-9, 2009

31. Restricted participation:

Unaccompanied children in interpreter-mediated asylum hearings in Sweden

Olga Keselman

ISBN: 978-91-7393-499-2, 2009 
32. Deaf people and labour market in Sweden.

Education - Employment - Economy.

Emelie Rydberg

ISBN: 978-91-7668-725-3, 2010

33. Social rättvisa i inkluderande idrottsundervisning

för elever med rörelsehinder - en utopi?

Kajsa Jerlinder

ISBN: 978-91-7668-726-0, 2010

34. Erfarenheter av rehabiliteringsprocessen mot ett arbetsliv

- brukarens och de professionellas perspektiv

Helene Hillborg

ISBN: 978-91-7668-741-3, 2010

35. Knowing me, knowing you - Mentalization abilities of children who use augmentative and alternative communication

Annette Sundqvist

ISBN: 978-91-7393-316-2, 2010

36. Lärare, socialsekreterare och barn som far illa - om sociala representationer och interprofessionell samverkan.

Per Germundsson

ISBN: 978-91-7668-787-1, 2011

37. Fats in Mind

Effects of Omega-3 Fatty Acids on Cognition and Behaviour in Childhood

Ulrika Birberg Thornberg

ISBN: 978-91-7393-164-9, 2011

38. "Jobbet är kommunikation"

Om användning av arbetshjälpmedel för personer med hörselnedsättning

Sif Bjarnason

Licentiate Degree. ISBN: 978-91-7668-835-9, 2011

39. Applying the ICF-CY to identify everyday life situations of children and youth with disabilities

Margareta Adolfsson

ISBN: 978-91-628-8342-3, 2011

40. Tinnitus - an acceptance-based approach

Vendela Zetterqvist

ISBN: 978-91-7393-040-6, 2011

41. Applicability of the ICF-CY to describe functioning and environment of children with disabilities

Nina Klang

ISBN: 978-91-7668-864-9, 2012 
42. Bringing more to participation

Participation in school activities of persons with Disability within the framework of the International Classification of Functioning, Disability and Health for Children and Youth (ICF-CY)

Gregor Maxwell

ISBN: 978-91-628-8484-0, 2012

43. From Eye to Us.

Prerequisites for and levels of participation in mainstream school of persons with Autism Spectrum Conditions

Marita Falkmer

ISBN: 978-91-637-2091-8, 2013

44. Otosclerosis, clinical long-term perspectives

Ylva Dahlin-Redfors

ISBN 978-91-628-8617-2, 2013

45. Tinnitus in Context - A Contemporary Contextual Behavioral Approach

Hugo Hesser

ISBN 978-91-7519-701-2, 2013

46. Hearing and middle ear status in children and young adults with cleft palate Traci Flynn

ISBN 978-91-628-8645-5, 2013

47. Utrymme för deltagande, beslutsprocesser i möten mellan patienter med ospecifika ländryggsbesvär och sjukgymnaster i primär vård

Iréne Josephson

ISBN 42-978-91-85835-41-6, 2013

48. Man vill ju klara sig själv" Studievardagen för studenter med Asperger syndrom i högre studier

Ann Simmeborn Fleischer

ISBN 978-91-628-8681-3, 2013

49. Cognitive erosion and its implications in Alzheimer's disease

Selina Mårdh

ISBN 978-91-7519-621-1, 2013

50. Hörselscreening av en population med utvecklingsstörning

Utvärdering av psykoakustisk testmetod och av OAE-registrering som

komplementär metod

Eva Andersson

Licentiate Degree. ISBN 978-91-7519-616-9, 2013 
51. Skolformens komplexitet - elevers erfarenheter av skolvardag och tillhörighet i gymnasiesärskolan

Therése Mineur

ISBN 978-91-7668-951-6, 2013

52. Evaluating the process of change:

Studies on patient journey, hearing disability acceptance and stages-of-change

Vinaya Kumar Channapatna Manchaiah

ISBN 978-91-7519-534-6, 2013

53. Cognition in hearing aid users: Memory for everyday speech

Hoi Ning (Elaine) $\mathrm{Ng}$

ISBN 978-91-7519-494-3, 2013

54. Representing sounds and spellings Phonological decline and compensatory working memory in acquired hearing impairment

Elisabet Classon

ISBN 978-91-7519-500-1, 2013

55. Assessment of participation in people with a mild intellectual disability

Patrik Arvidsson

ISBN 978-91-7668-974-5, 2013 